\title{
A Detection-Level Hazardous Waste Ground-Water Monitoring Compliance Plan for the 200 Areas Low-Level Burial Grounds and Retrievable Storage Units
}

February 1987

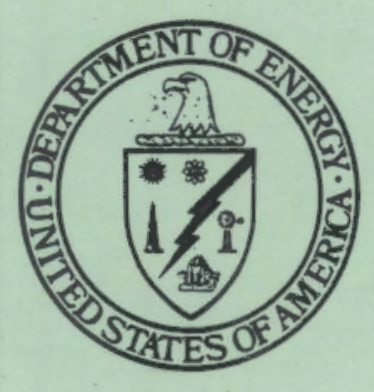

Prepared by the Pacific Northwest Laboratory for the U.S. Department of Energy Richland Operations Office 


\begin{abstract}
A DETECTION-LEVEL HAZARDOUS WASTE GROUND-HATER MONITORING COMPLIANCE

PLAN FOR THE 200 AREAS LOW-LEVEL BURIAL GROUNDS AND RETRIEVABLE STORAGE UNITS
\end{abstract}

February 1987

Prepared for

the U.S. Department of Energy

by the

Pacific Northwest Laboratory

Richland, Washington 99352 
Notice - The procedures and preliminary interpretations in this document reflect conditions in 1986 and are thus subject to change as a result of on-going technical audits and reviews. 


\section{CONTENTS}

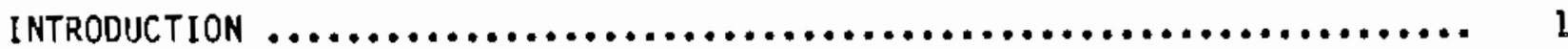

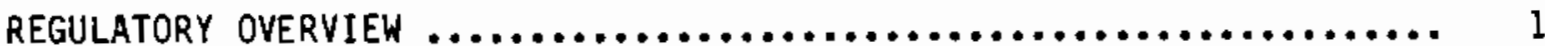

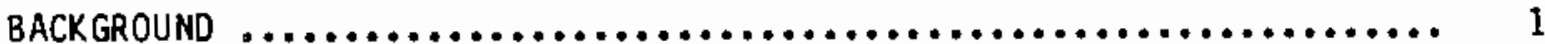

Regional Physlography and Geology ..................... 3

Hydrogeology of the 200 -West Area...$\ldots \ldots \ldots \ldots \ldots \ldots \ldots$ ?

Hydrogeology of the $200-$ East Area $\ldots \ldots \ldots \ldots \ldots \ldots \ldots \ldots \ldots \ldots . \ldots . \ldots 22$

Hydrology of the Unconfined Aquifer ..................... 35

Burial Ground 0perations .......................... 38

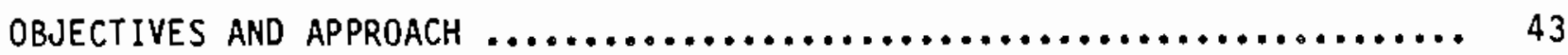

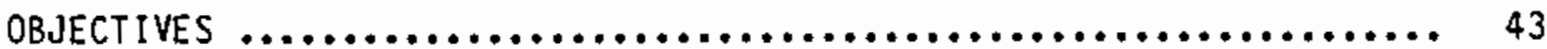

MODELING $\ldots \ldots \ldots \ldots \ldots \ldots \ldots \ldots \ldots \ldots \ldots \ldots \ldots \ldots \ldots \ldots \ldots \ldots \ldots \ldots \ldots \ldots \ldots \ldots$

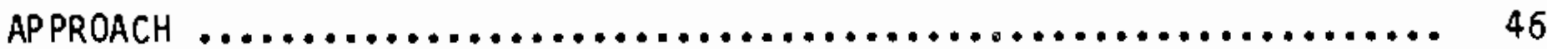

Assessment of the Unsaturated Zone .................... 46

COMPLIANCE IMPLEMENTATION PLAN AND SCHEDULE ................... 51

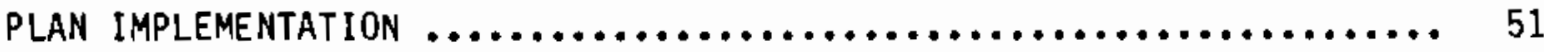

Well Installation $\ldots \ldots \ldots \ldots \ldots \ldots \ldots \ldots \ldots \ldots \ldots \ldots \ldots \ldots \ldots \ldots \ldots \ldots$

Sample Coltection and Analysis ....................... 57

Water Level Measurements $\ldots \ldots \ldots \ldots \ldots \ldots \ldots \ldots \ldots \ldots \ldots \ldots \ldots \ldots . \ldots . \ldots$

Well Specifications $\ldots \ldots \ldots \ldots \ldots \ldots \ldots \ldots \ldots \ldots \ldots \ldots \ldots \ldots \ldots \ldots$

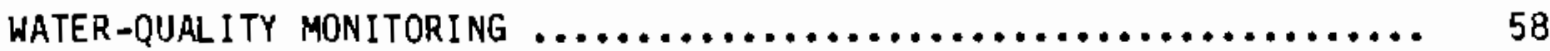

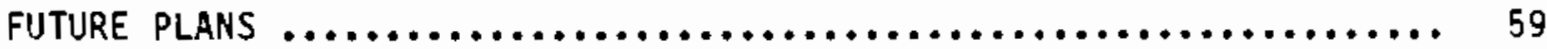

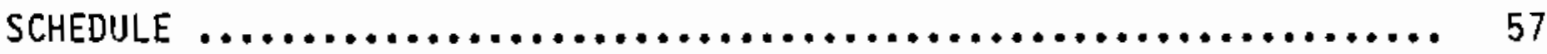

REPORTING $\ldots \ldots \ldots \ldots \ldots \ldots \ldots \ldots \ldots \ldots \ldots \ldots \ldots \ldots \ldots \ldots \ldots \ldots \ldots \ldots \ldots \ldots \ldots \ldots \ldots$

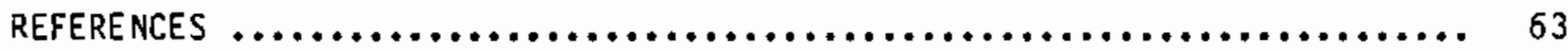




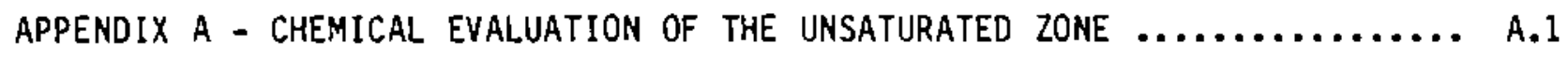
APPENDIX $B$ - ENGINEERING STUDY $\ldots \ldots \ldots \ldots \ldots \ldots \ldots \ldots \ldots \ldots \ldots \ldots \ldots \ldots \ldots \ldots \ldots \ldots \ldots$

APPENDIX $C$ - WELL SPECIFICATIONS--STATEMENT OF WORK $\ldots \ldots \ldots \ldots \ldots \ldots \ldots \ldots$ APPENDIX D - PROCEDURES FOR SAMPLE COLLECTION, CHAIN-OF-CUSTODY, ANO FIELD MEASUREMENTS .......................... 0.1

APPENDIX E - QUALITY ASSURANCE PLAN $\ldots \ldots \ldots \ldots \ldots \ldots \ldots \ldots \ldots \ldots \ldots \ldots \ldots \ldots \ldots \ldots$

APPENDIX F - ANALYTICAL METHODS AND QUALITY CONTROL PROCEDURES ......... F.1 


\section{FIGURES}

1 Location of the 200 Areas on the Hanford Site ................. 2

2 Stratigraphy of the Hanford Site $\ldots \ldots \ldots \ldots \ldots \ldots \ldots \ldots \ldots \ldots \ldots \ldots \ldots$

3 Location of Geologic Cross Sections in the 200-East

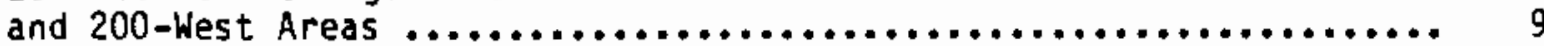

4 Cross Section $A-A^{\prime} \ldots \ldots \ldots \ldots \ldots \ldots \ldots \ldots \ldots \ldots \ldots \ldots \ldots \ldots \ldots \ldots \ldots \ldots \ldots \ldots 11$

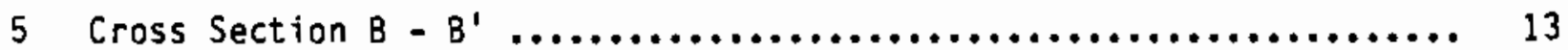

$6 \quad$ Cross Section $C-C^{1} \ldots \ldots \ldots \ldots \ldots \ldots \ldots \ldots \ldots \ldots \ldots \ldots \ldots \ldots \ldots \ldots \ldots \ldots \ldots$

7 Cross Section $D-D^{\prime} \ldots \ldots \ldots \ldots \ldots \ldots \ldots \ldots \ldots \ldots \ldots \ldots \ldots \ldots \ldots \ldots \ldots \ldots \ldots \ldots$

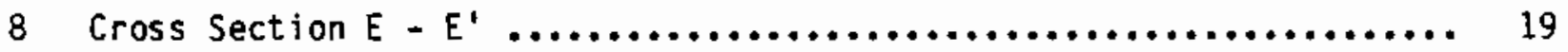

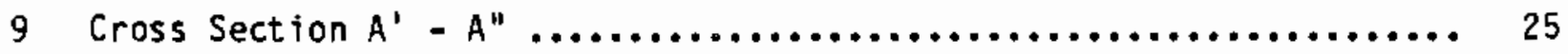

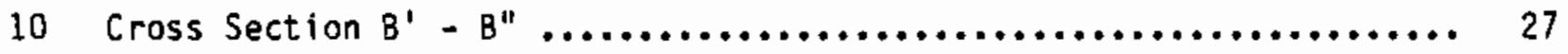

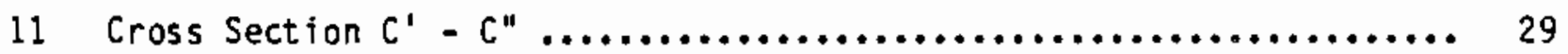

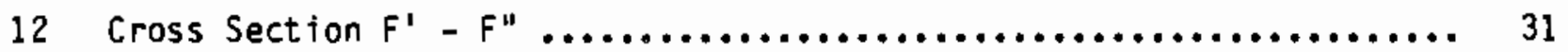

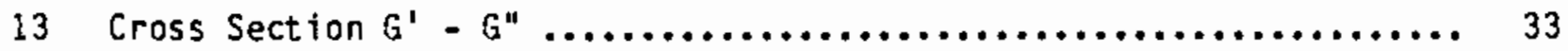

$14 \quad 200$ Area Water Table Map Showing Directions of

15 Location Map of Burial Grounds and Waste Management Areas

in the 200 -West Area ..................................... 44

16 Location Map of Burial Grounds and Waste Management Areas

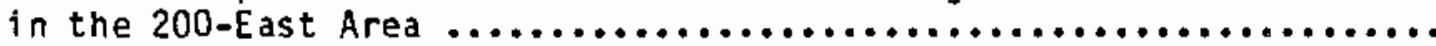

17 Location Map of Planned Clusters and Single Monitoring

Wells in the 200-West Area

18 Location Map of Planned Single Monitoring Wells in the 200-East Area

19 Planned Construction of Monitoring Weils ................... 56

20 Well Completion Schedule $\ldots \ldots \ldots \ldots \ldots \ldots \ldots \ldots \ldots \ldots \ldots \ldots \ldots \ldots \ldots \ldots \ldots . \ldots \ldots$ 
. . 


\section{INTRODUCTION}

This plan defines the actions needed to achieve detection-level monitoring compliance at the Hanford Site 200 Areas Low-Level Burial Grounds (LLBG) in accordance with the Resource Conservation and Recovery Act (RCRA) as described in 40 CFR 265(f) and the Washington Administrative Code (WAC 173-303). Compliance will be achieved through characterization of the hydrogeology and monitoring of the ground water beneath the LLBG located in the Hanford Site 200 Areas (Figure 1).

\section{REGULATORY OVERVIEW}

The U.S. Department of Energy (USDOE) submitted Part A and Part B permit applications based on interpretation of the regulations concerning radioactive mixed waste (i.e., waste with both radioactive and hazardous chemical components) to the U.S. Environmental Protection Agency (EPA) and the Washington State Department of Ecology. The USDOE applied for a total waiver from groundwater monitoring requirements for the LLBG as allowed under 40 CFR 265.90(c) and WAC 173-303-806. In lieu of pursuing that application for a total waiver, the USDOE plans to install 35 wells during the next year to monitor the ground water under the LLBG. Additional wells may be drilled, as pianned and appropriate, in subsequent years based upon data from the initial well system. This plan details the initial phase of the approach the USDOE intends to take in complying with the ground-water monitoring requirements.

\section{BACKGROUND}

Information about the 200 Areas' hydrogeologic system, design of the existing radiologic-monitoring well network, and previous radioactive contaminant releases provides the basis for preparing a list of specific objectives and developing a technically sound approach to detection-level monitoring of the LLBG. This information is summarized in the following sections. 


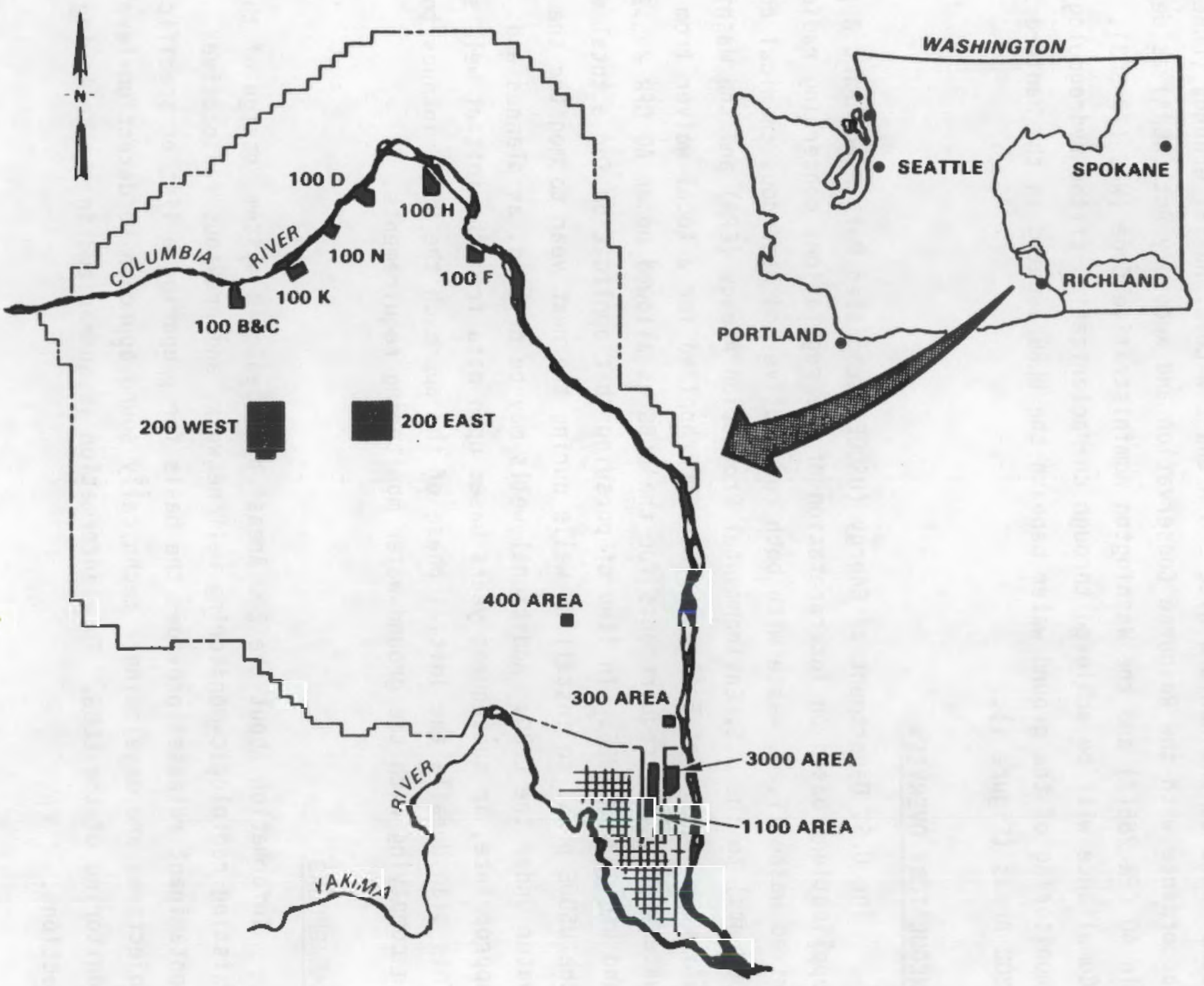

FIGURE 1. Location of the 200 Areas on the Hanford Site 
Regional Physiography and Geology

The Hanford Site is located in the Pacific Northwest in a semiarid region of southcentral Washington State. This portion of the state lies within the Columbia River Plateau that is generally defined by a thick accumulation of basaltic lava flows which extend laterally from central Washington eastward into Idaho and southward into Oregon (Tallman et a1. 1979). Deformation of these lava flows has formed a number of broad structural and topographic basins. The Hanford Site lies withir one of these, the Pasco Basin, near the confluence of the Yakima and Columbia Rivers.

The boundaries of the Pasco Basin are defined by anticlinal structures of basaltic rock. These structures are the Saddle Mountains to the north; the Umt anum Ridge, Yakima Ridge, and Rattlesnake Hills to the west; and the Rattlesnake Hills and a series of doubly plunging anticlines merging with the Horse Heaven Hills to the south. The terrain within the Pasco Basin is relatively flat, its features formed by catastrophic floods and, more recently, by the development of sand dunes (USDOE 1986).

The Separation Areas (200 Areas) located near the center of the Hanford Site, lie on a broad flood bar. This bar is commonly referred to as the 200 Area Plateau. Activities of the USDOE and its contractors in this portion of the Hanford Site have resulted in the storage, disposal, and accidental release of radionuclides and other industrial wastes.

The major geologic units beneath the 200 Areas are, in ascending order: basement rocks of undetemined origin; the Columbia River Basalt Group with intercalated sediments of the Ellensburg Formation; the Ringold Fomation; the Plio-Pleistocene unit; and the Hanford formation (Figure 2). The surface of the 200 Areas is veneered with loess and sand dunes of varying thickness.

\section{Columbia River Basalt Group}

The regional geology is dominated by the thick sequence of tholeitic flood basalts designated the Columbia River Basait Group. This layered sequence consists of more than $200,000 \mathrm{~km}^{3}$ of basalt and is subdivided into five formations (Ledgerwood and 0eju 1978; Swanson et al. 1979). This basalt sequence accumulated in the subsiding Pasco Basin to a thickness of at least 


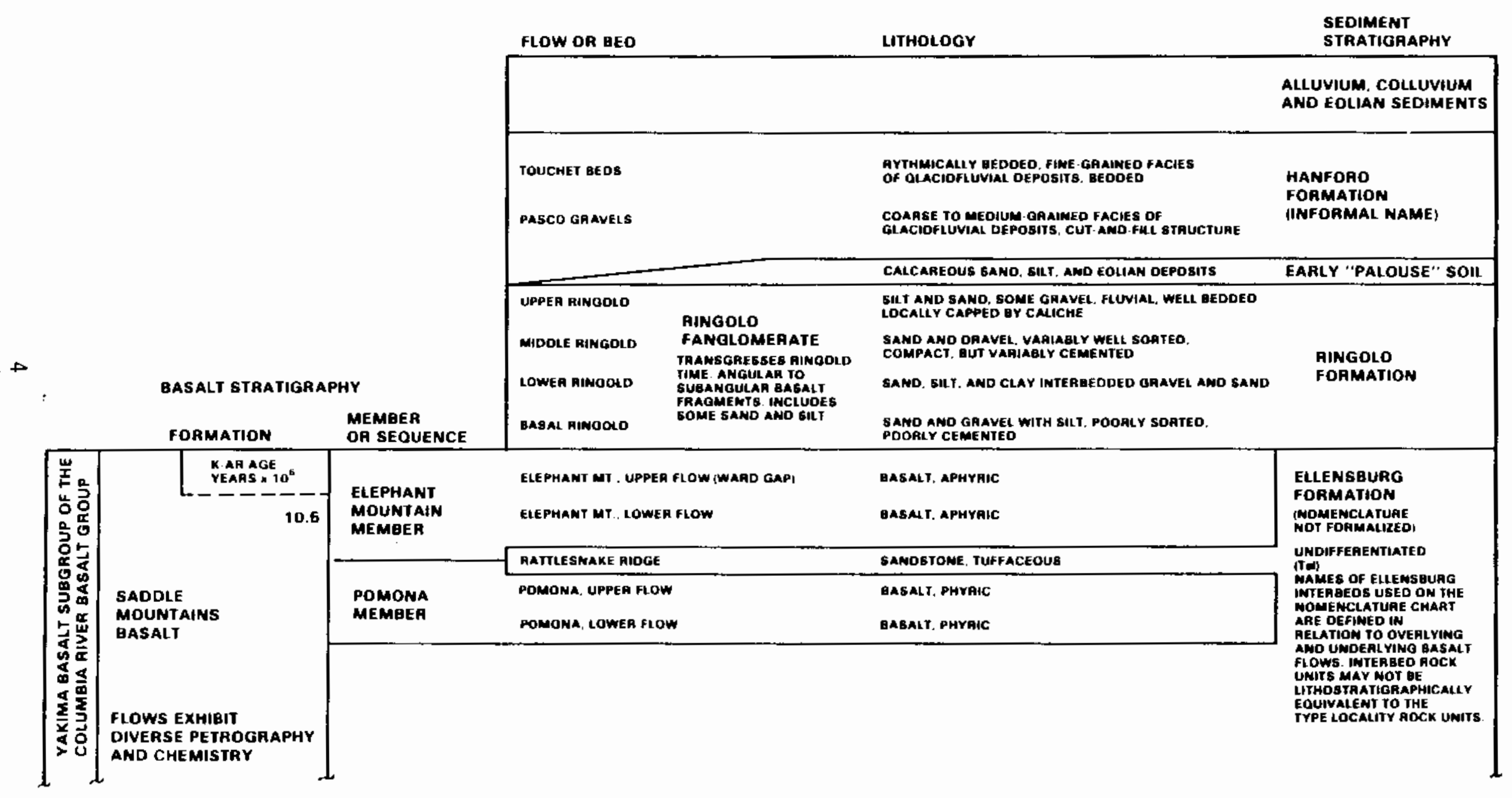

FIGURE 2. Stratigraphy of the Manford Site 
$1460 \mathrm{~m}$ and as much as $4267 \mathrm{~m}$ (Myers and Price et al. 1979). Approximately 100 basalt flows, including both Columbia River Basalts and older lavas, have been identified (Swanson et al. 1979). Flows of the Columbia River Basalt Group are interbedded with and overlain by Miocene-Pliocene epiclastic and volcaniclastic sediments of the Ellensburg Formation (Myers and Price et al. 1979). These sedimentary interbeds become thicker and more frequent in the Saddle Mountain Formation of the Columbia River Basalt Group.

Continued subsidence following the cessation of the volcanism that formed the Columbia River Basalt Group resulted in further accumulation of sediments in the Pasco Basin. Sediments of the Ringold Formation were deposited in a fluvial/flood plain environment between 3.7 and about 8.5 million years before present (mybp) (Myers and Price et al. 1979). These sediments accumulated to a thickness of over $365 \mathrm{~m}$.

\section{Ringold Formation}

Beneath the central portion of the Pasco Basin, including the 200 Areas, the Ringold Fomation has been divided into four textural units; 1) sand and gravel of the basal Ringold member; 2) clay, silt, and fine sand with minor gravel lenses of the lower Ringold member; 3) occasionally cemented sand and gravel of the middle Ringold member; and 4) silt and fine sand of the upper Ringold member (Brown 1959).

The silts and sands of the lower member were deposited in still-forming synclinal depressions. This low-energy fluvial/lacustrine deposit is thickest in the Cold Creek Syncline. The unit pinches out on the flanks of the UmtanumGable Mountain Structure where it apparently was not deposited.

The middle member is the thickest Ringold member beneath the Separation Areas. This member is characterized as a silty, sandy gravel. In general, the upper part of the middle Ringold is not indurated except for isolated cementation from calcium carbonate, while the lower part of the unit is moderately-towe 11 indurated.

The upper Ringold member is present only beneath parts of the 200-West Area. This silty sand member contains several caliche horizons indicating that the eroded surface of the unit was exposed to subarial processes of a 
semiarid-to-arid environment comparable to that of the present day. The upper Ringold member apparently was completely stripped by erosional processes throughout the remainder of the Separation Areas.

\section{Plio-Pleistocene Unit}

Eolian silt and fine sand of the Plio-Pleistocene unit overlie the Ringold Formation in the western part of the Hanford Site (Brown 1960). Relatively high caliche contents are found in much of this unit. Normal fluvial processes as well as Pleistocene catastrophic flooding apparently stripped much of this eolian deposit from beneath the Separation Areas (Tallman et al, 1979).

\section{Hanford Formation}

The Hanford formation lies on the eroded surface of the Plio-Pleistocene unit, the Ringold Formation, and locally, the basalt bedrock. The Hanford formation consists of catastrophic flood sediments that were deposited when ice dams in western Montana and northern Idaho were breached and mass ive volumes of water spilled abruptly across eastern and central washington. The floods scoured the land surface, locally eroding the Ringold Formation, the basalts, and sedimentary interbeds, and left a network of buried channels crossing the Pasco Basin (Tallman et a1. 1979). Thick sequences of sediments were deposited by several episodes of Pleistocene flooding with the last major flood sequence dated at about 13,000 years before present (Myers and Price et al. 1979). These sediments have locally been divided into two main facies, termed the "Pasco Gravels" facies and the "Touchet Beds" facies (Myers and Price et a1. 1979).

The Pasco gravels (Tallman et al. 1979) facies is composed of poorly sorted, subrounded-to-angular clasts that commonly display forset bedding (Myers and Price et al. 1979). These sediments indicate high-energy depositional environments. The Touchet Beds facies consists of rhythmically bedded sequences of graded silt, sand, and minor gravel units. These deposits are limited to areas where slack-water conditions occurred during the impoundment of flood waters behind the Wallula Gap constriction (Tallman et al. 1979; Myers and Price et al. 1979). 
Eolian sediments consisting of both active and inactive sand dunes locally veneer the surface of the 200 Areas.

Hydrogeology of the 200-West Area

Hydrogeologic units of principle interest are, in ascending order: the Pomona member, a thick and dense basalt flow(s) that forms the base of the Rattlesnake Ridge aquifer; the Rattlesnake Ridge interbed, which forms the physical framework of the uppemost basalt aquifer; the Elephant Mountain member, which forms the confining bed over the Rattlesnake Ridge aquifer; the Ringold Formation, which forms the framework of the locally confined basal Ringold aquifer and the unconfined aquifer; and the Plio-Pleistocene unit and Hanford formation, which form the framework of the unsaturated (vadose) zone, Figure 2.

\section{Pomona Member}

The Pomona member averages about $45 \mathrm{~m}$ thick beneath the 200-West Area, and thins to the northwest (Myers and Price et al. 1984). Northeast of the site, on Gable Mountain, the Pomona displays four intraflow structures; a basal colonnade, an entablature, an upper colonnade, and a flow top (Fecht 1978). The interior of the Pomona is dense and exhibits very low pemeability.

\section{Rattlesnake Ridge Interbed}

The Rattlesnake Ridge interbed was deposited on the weathered surface of the Pomona. Its thickness averages about $27 \mathrm{~m}$. Locally, it has been divided into four facies on the basis of composition. These facies are, in ascending order: 1) a clay-like basalt conglomerate fomed by the weathering and reworking of the Pomona flow top, 2) an epiclastic fluvial-floodplain unit deposited by the ancestral Columbia River system, 3) a tuff made up of an air-fall ash, and 4) a tuffite derived from fluvial reworking of the tuff and epiclastic detritus (Graham et al. 1984). The tuff and tuffite units exhibit higher natural radioactivity (as indicated by natural gamma logs) and high glass content in borehole samples. These units remain relatively constant in grain size 
but vary in thickness. Grain size, in the epiclastic unit, ranges from sandy gravel to sands and silts, which appear to interfinger and grade laterally into one another.

The Rattlesnake Ridge interbed forms the uppemost, regionally extensive confined aquifer. The different lithologies produce some degree of anisotropy and heterogeneity within the aquifer.

\section{Elephant Mountain Member}

The Elephant Mountain member ( 10.5 mybp) is the uppermost and youngest basalt merber beneath 200-West Area. It is generally conformable to the surface of the Rattlesnake Ridge interbed, but in areas has been found to be invasive into the underlying sediments (Fecht 1978). The member consists of two flows or flow lobes. Only the lowemost flow (Elephant Mountain I) is present, averaging about $87 \mathrm{~m}$ in thickness. Fecht (1978) describes three intraflow structures in the lower flow. These are, in ascending order: colonnade, entablature, and flow top. The interior of the Elephant Mountain I flow is dense with very low hydraulic conductivities typical of the Columbia River Basalts. This low hydraulic conductivity acts to confine the Rattlesnake Ridge aquifer (Graham et al. 1984).

\section{Ringold Formation}

The Ringold Formation is present and continuous beneath the 200-West Area. Its thickness averages $120 \mathrm{~m}$ (Tallman et al. 1979), thickening to the southwest. All four textural units (basal, lower, middle, and upper) are present; only the upper Ringold is discontinuous. The distribution of these sediments is shown in the cross sections through the area, Figures 3 through 8.

The basal Ringold unit, the oldest and lowemost, directly overlies and is conformable to the Elephant Mountain member. It averages about $15 \mathrm{~m}$ thick and thickens as it dips to the southwest. The basal Ringold is predominately a matrix- (sand-) supported grave? unit with stringers of coarse-to-fine sand and silt. Beneath the 200-West Area, where the basal Ringold is capped by the lower Ringold, it forms a confined aquifer.

The lower Ringold unit occurs throughout the site and averages approximately $15 \mathrm{~m}$ thick. The surface of the unit dips to the southwest where it also 


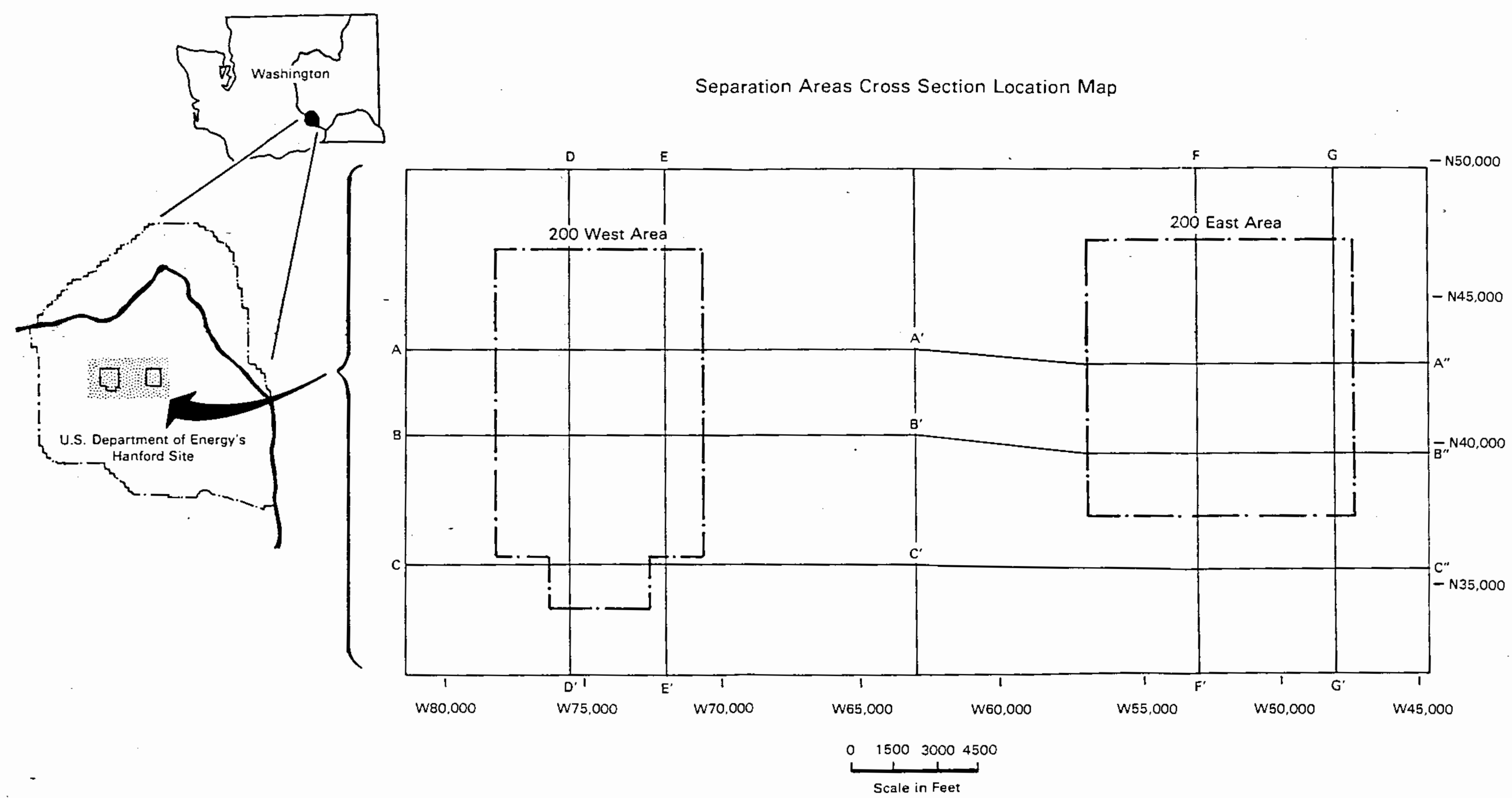

FIGURE 3. Location of Geologic Cross Sections in the 200-East and 200-West Areas (after Tallman et al, 1979) 



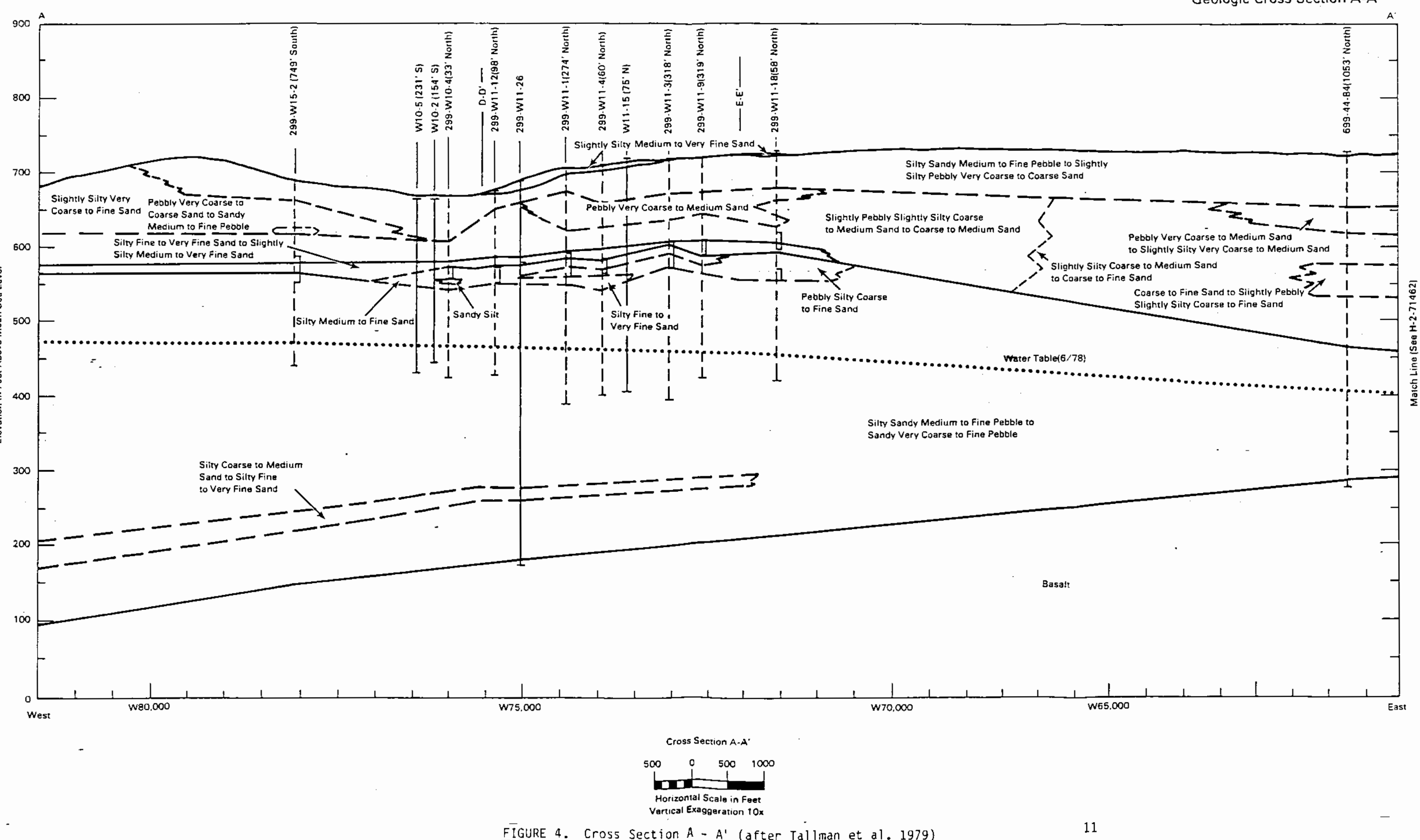





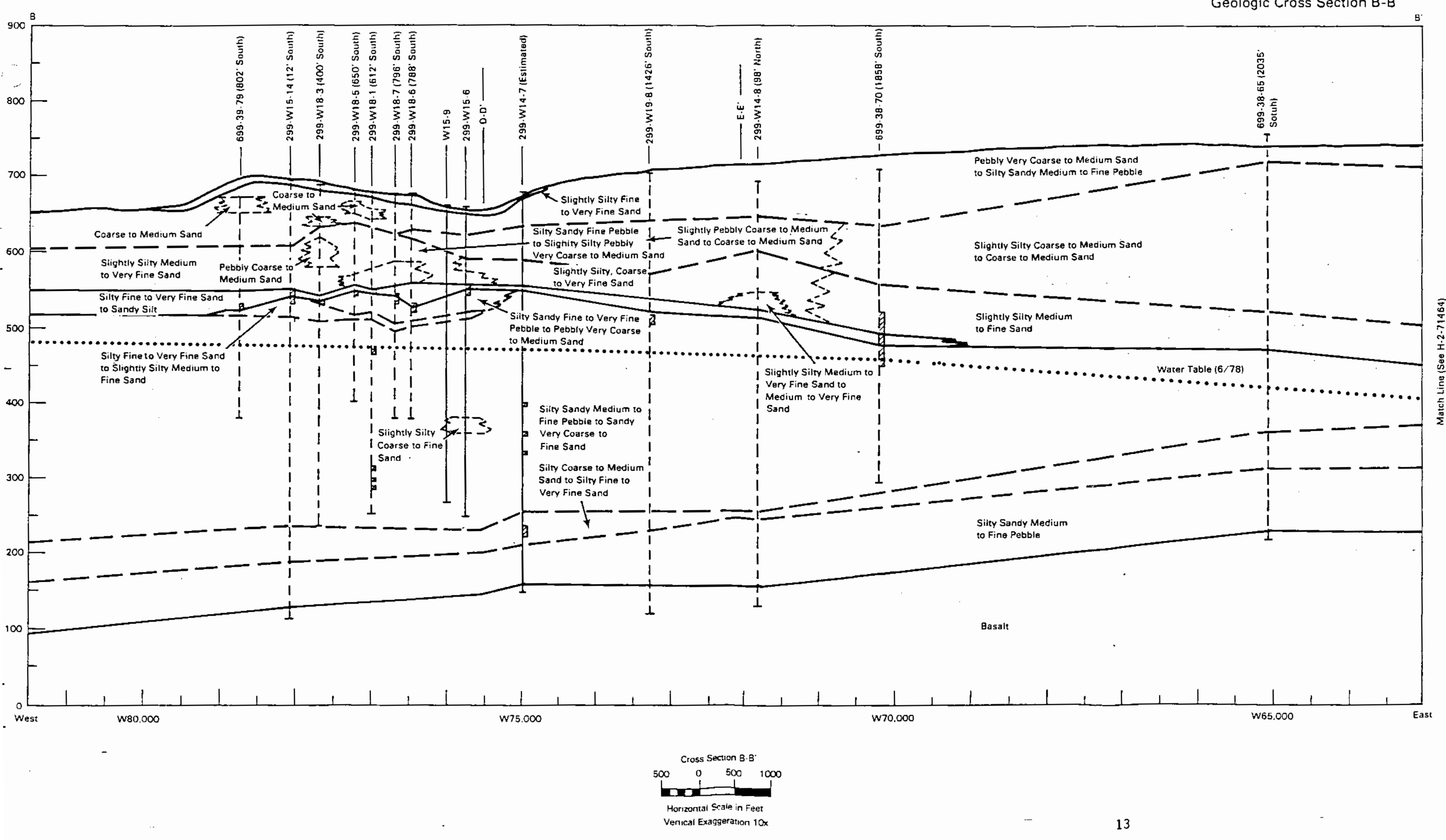

FIGuRE 5. Cross Section B - B' \{after Tallman et al. 1979 



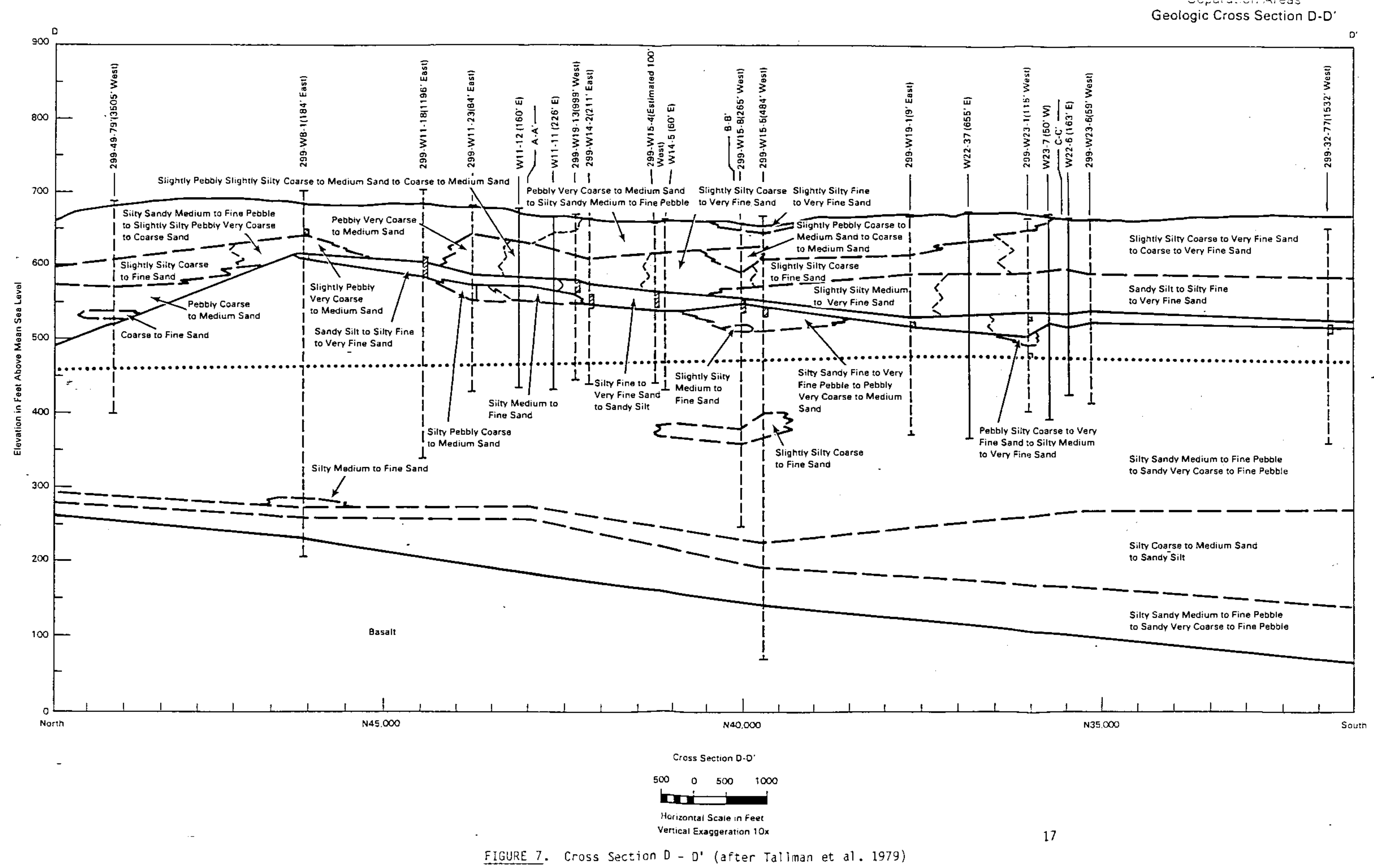


' 


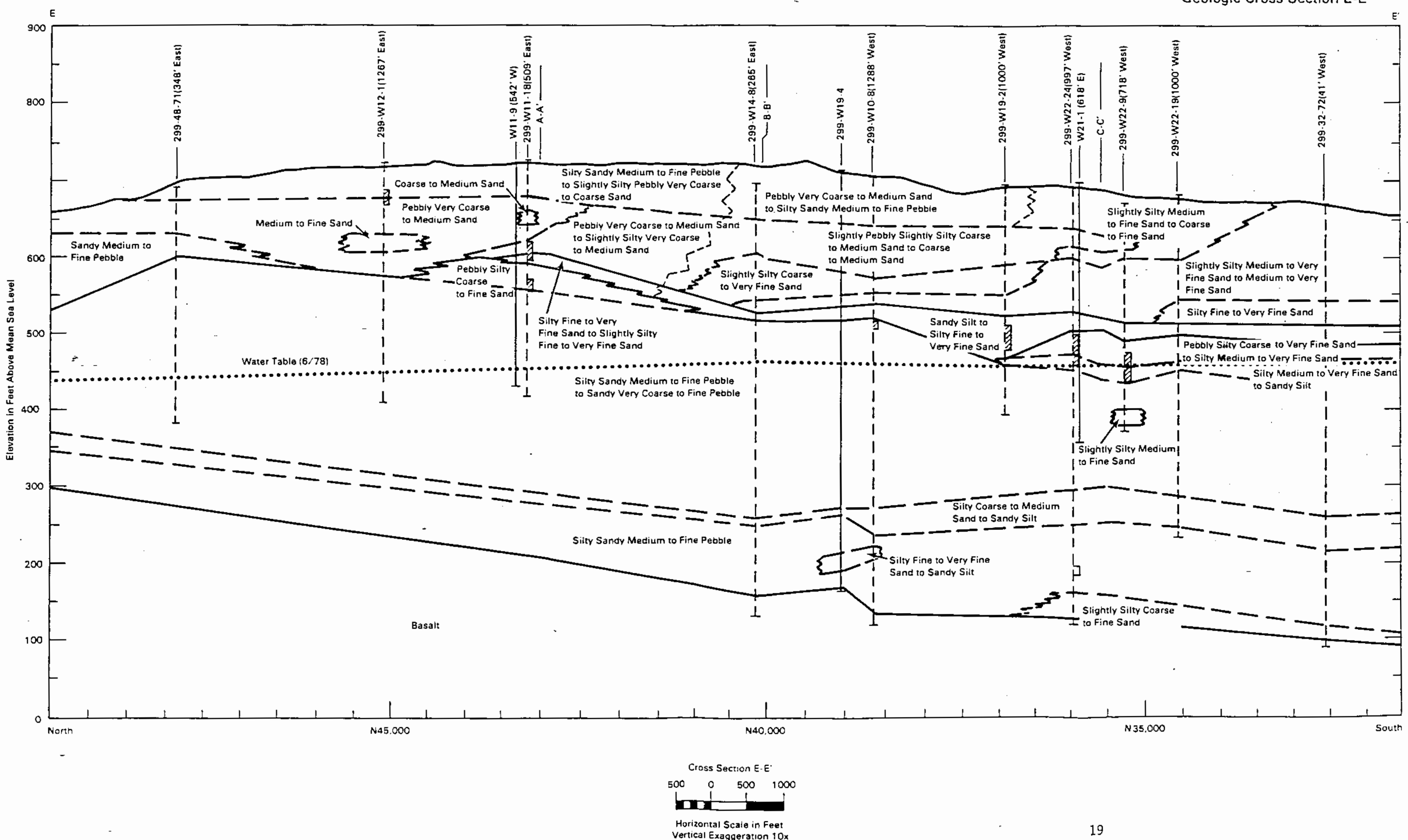


thickens. The texture of this unit ranges from a silty coarse-to-medium sand to sandy silt to clay, generally becoming finer from north to south. Stringers of coarse-to-fine pebbles, up to $1 \mathrm{ft}$ thick, are common. Also, fine pebbles are found scattered throughout beds within the unit. The lower Ringold has hydraulic conductivities of 1 to $1.36 \mathrm{~m} /$ day (Graham 1981 ) and serves to confine the basal Ringold aquifer.

The silty, sandy gravel of the middle Ringold unit is also present throughout the 200-West Area. This unit is the major constituent of the Ringold Fomation, averaging about $90 \mathrm{~m}$ thick, thinning to the north and east. The unit consists of well-rounded pebbles and small cobbles with a matrix of coarse-to-fine sand and silt. The amount of cementation varies but generally is greatest in the lower part of the unit, where it is moderately-to-well indurated with calcium carbonate and/or silica. Silt and sand lenses up to $5 \mathrm{~m}$ thick are present within the conglomerate. This unit forms the framework of the unconfined aquifer.

The sand, silt, and clay of the upper Ringold are present, but discontinuous beneath the 200-West Area. Where present, its thickness averages about $6 \mathrm{~m}$. The unit is composed of well-sorted sand and silt with minor lenses of fine pebbles. A caliche horizon often caps the upper Ringold. Other caliche horizons have been identified throughout the unit.

\section{Plio-Pleistocene Unit}

The Plio-Pleistocene unit lies unconformable on the upper and middle Ringold members beneath nearly all of the 200-West Area. This unit resulted from the reworking and redeposition of the sediments of the upper Ringold, averages about $6 \mathrm{~m}$ in thickness. The sediments are typically fine-grained, consisting predominantly of very fine sand and silt. A relatively high calcium carbonate content is present in the eolian silts, suggesting that the deposit contains reworked caliche from the upper Ringold member (Tallman et al. 1979).

Hanford Formation

The major surface and near-surface sand and gravel deposits in the 200-West Area are glaciofluvial sediments of the Hanford formation. The thickness of the Hanford formation averages about $45 \mathrm{~m}$ and is composed of the 
Pasco Gravel facies. Beneath the 200-West Area, these sediments can be further broken down into three main units based on texture. The lowermost unit is a slightly silty medium-to-very-fine sand. It is present only in the southern half of the site and becomes finer to the south. The middle unit, a pebbly coarse-to-medium sand to slightly silty coarse-to-medium sand, is present throughout the 200-West Area, except for areas to the north and west. The unit averages about $25 \mathrm{~m}$ thick, and generally grades from coarse sediments in the northwest to finer sediments in the south and west. The uppermost textural unit of the Hanford formation in the 200-West Area is a silty sandy gravel to slightly silty very-coarse-to-coarse sand. This unit forms the surficial materials of the 200-West Area, except in the extreme south where it is not present, or local deposits of eolian loess occur. As with the other Hanford units, these sediments also appear to become finer to the south.

A common feature of the Hanford formation is the occurrence of clastic dikes (Black 1979). These features have been identified in tank farm excavations in the southern portion of the area. These sedimentary structures are vertically planed features, and are generally filled with well-sorted clay to very coarse sand-size clastic sediments. These features can affect the movement of waste water in the vadose zone, generally enhancing downward movement (Talliman et al. 1979).

Small localized deposits of loess cover portions of the Hanford formation to a depth of approximately $3 \mathrm{~m}$.

Hydrogeology of the 200-East Area

The geologic units of principal interest are the same in the 200-East Area as they are in the 200-West Area. There are, however, some notable differences in the occurrence of specific units, and in the thickness and extent of those units. Areas north and east of the 200-East Area (Gable Mountain Pond and $B$ Pond) are incorporated into this discussion.

\section{Pomona Member}

The Pomona member, which forms the base of the Rattlesnake Ridge aquifer, averages about $56 \mathrm{~m}$ thick beneath this portion of the Hanford Site, and thickens slightly to the south. On the western Gable Mountain anticline it is 
typified by four major intraflow structures: basal colonnade, entablature, upper colonnade, and flow top (Fecht 1978). The interior of the Pomona member is dense and exhibits very low pemeability.

\section{Rattlesnake Ridge Interbed}

The Rattlesnake Ridge interbed beneath the 200-East Area is equivalent to the unit under the 200-West Area as described above. This unit is the uppermost, regionally extensive confined aquifer in the area. As beneath the 200-West Area, the varying lithologies produce some degree of anisotropy and heterogeneity affecting the flow of ground water.

Elephant Mountain Member

The Elephant Mountain member (10.5 mybp) is the uppermost and youngest basalt member beneath this area, and is generally conformable to the surface of the Rattlesnake Ridge interbed. In some areas, the Elephant Mountain member has been found to be invasive into the underlying sediments (Fecht 1978). The basalt member consists of two flows or flow lobes. The lowemost flow (Elephant Mountain 1 ) is continuous over most of this area, ranging in thickness from 35 to $11.5 \mathrm{~m}$ (where it is partially eroded away), thinning to about $6 \mathrm{~m}$ over Gable Mountain. Fecht (1978) describes three intraflow structures in the lower flow. These are, in ascending order: colonnade, entablature, and flow top. The upper flow (Elephant Mountain II) is present only in the southeast and northern portions of the area. This flow is roughly 0.25 the thickness of the Elephant Mountain I flow (averaging $7.7 \mathrm{~m}$ ) and thickening to the southeast and north. An interflow zone separates the two flows. This interflow zone has interconnecting vesicles and rubbly zones.

The Elephant Mountain member forms the bedrock surface beneath the area, except where it has been locally eroded, exposing the older units. Much of this erosion occurred during the deposition of Ringold sediments, as the ancestral Columbia River flowed through the structural low west of Gable Mountain (Graham et a1. 1984). Further erosion occurred following deposition of the Ringold Formation, as Pleistocene catastrophic floods inundated the area. Both the Elephant Mountain I and II flows are dense, low pemeability, basalt flows with very low hydraulic conductivities typical of the Columbia River Basalts. 


\section{Ringold Formation}

The Ringold Formation is present beneath the site except near Gable Mountain where the formation was apparently not deposited, and in the area north of the 200-East Area, where main stream currents of late Pleistocene flooding have completely removed it (Graham et al. 1984). The Ringold Formation averages approximately $60 \mathrm{~m}$ thick beneath the 200-East Area, $40 \mathrm{~m}$ thick beneath B Pond, and is absent beneath Gable Mountain Pond. All four textural units--basal, lower, middle, and upper--have been identified. The distribution of these sediments is shown in Figures 3 and 9 through 13 .

The basal Ringold directly overlies the Elephant Mountain member. In the southern portion of the area, it is overlain by the lower Ringold and is well defined. In the central portion of the area, the lower Ringold apparently pinches out, making definition of the basal Ringold difficult due to its similarities to the now overlying middle Ringold (Graham et al. 1984). The basal Ringold averages about $22 \mathrm{~m}$ thick and thickens to the south.

The lower Ringold ranges from silty coarse-to-medium sand, to a sandy silt, to clay (Tallman et al. 1979) and locally includes some gravel stringers. The lower Ringold sediments are generally compacted and exhibit a variety of degrees of induration.

The middle Ringold unit occurs throughout the area except over Gable Mountain and in the deeply eroded channels adjacent to Gable Mountain. Its thickness averages approximately $30 \mathrm{~m}$ in the southern part of the area, thinning toward the north and east. Erosion has modified the surface of the middle Ringold. Reworked portions are often difficult to differentiate from the undisturbed portions. The unit consists of well-rounded pebble-to-cobble-size gravel with a matrix of sand, silt, and some clay. Induration of the unit ranges from virtually no cement to well-cemented by calcium carbonate and/or silica. Consolidation of the unit ranges from matrix-supported conglomerate to open-work uncemented gravel (Tallman et al. 1979).

The upper Ringold is identified only near $B$ Pond and consists of a fineto-very-fine sand, averaging about $3 \mathrm{~m}$ thick. The unit was likely not deposited on Gable Mountain, and elsewhere it has been eroded away. 


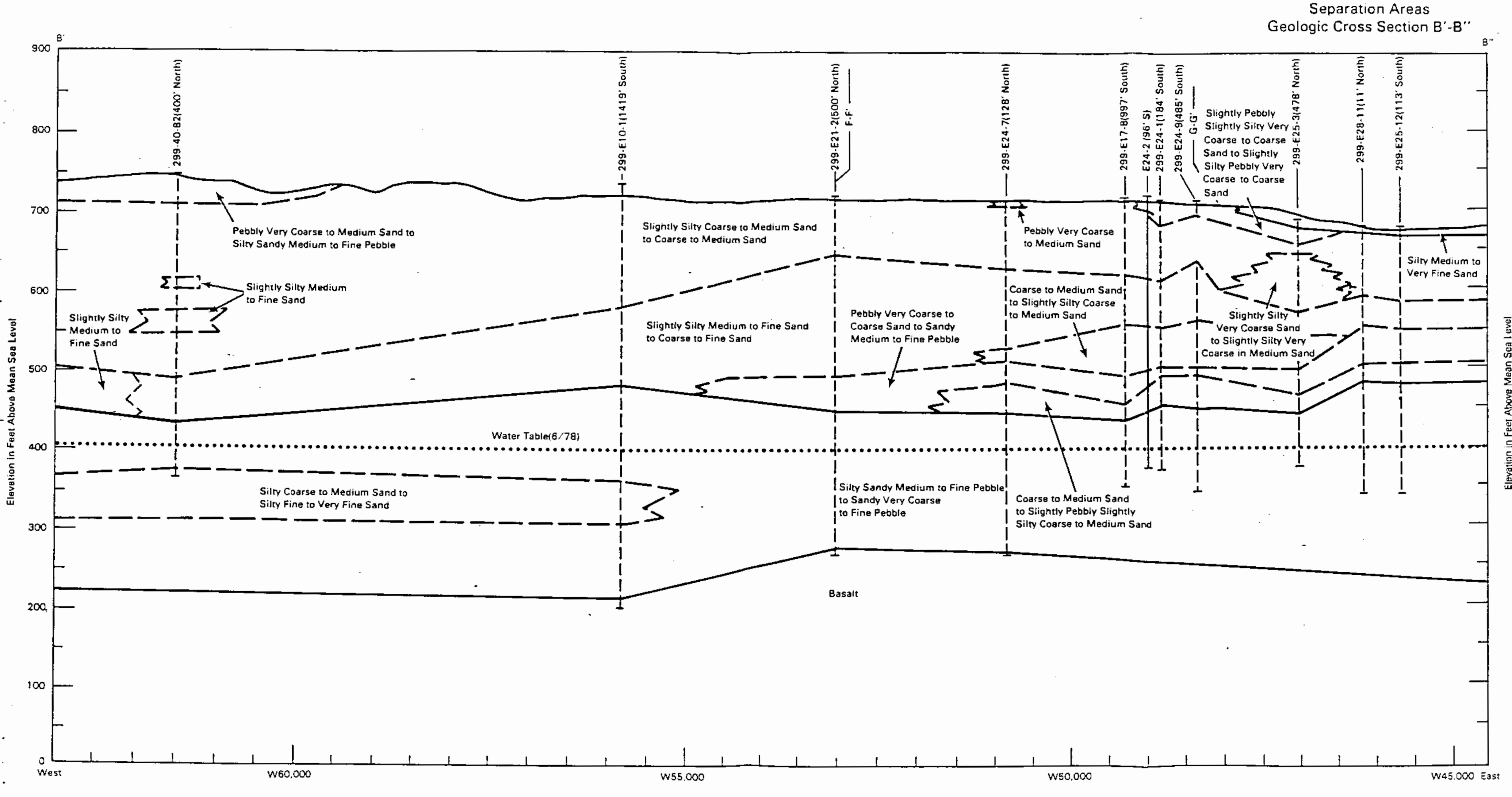


. 


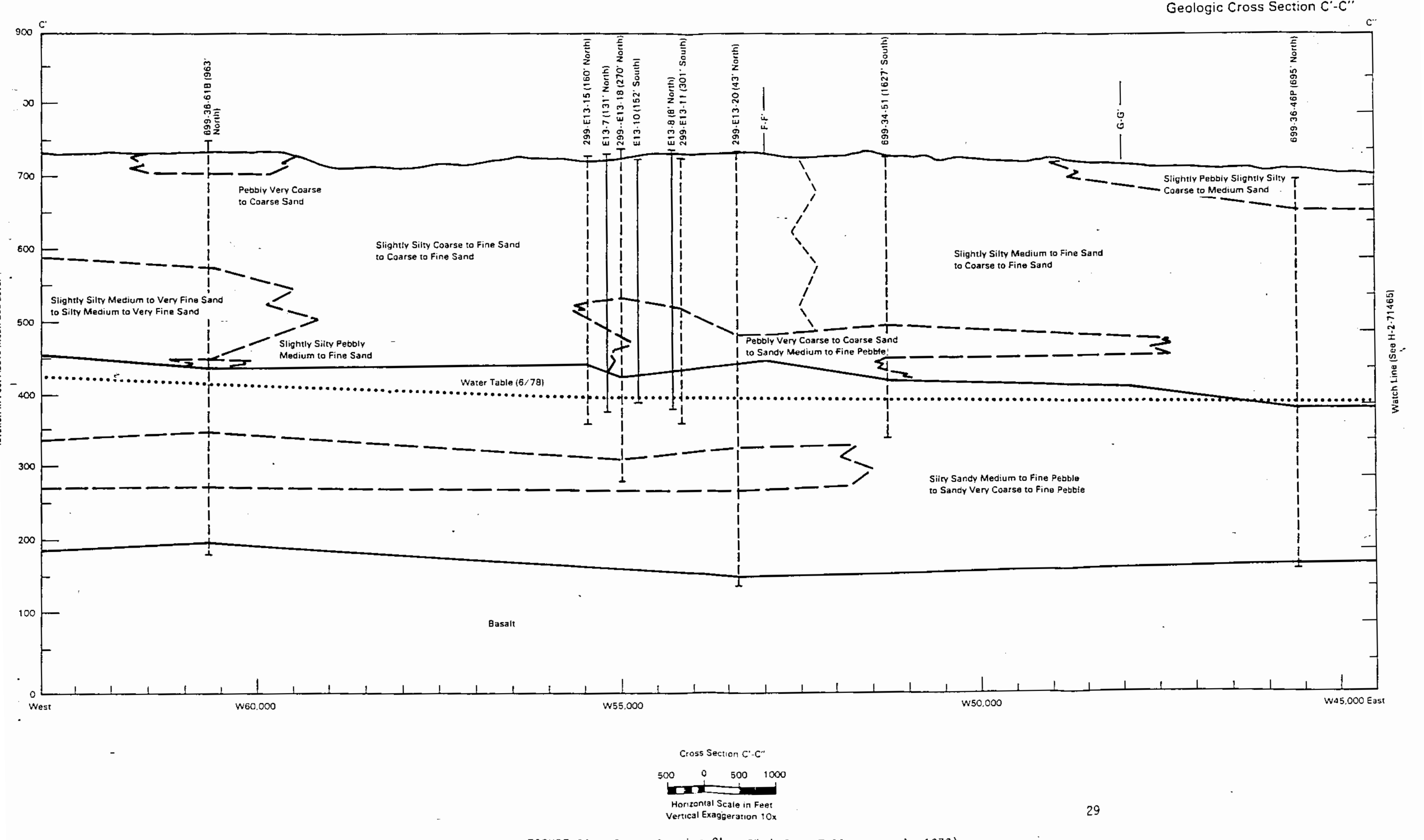

FIGURE 11. Cross Section C' - C" (after Taliman et al. 1979) 
, , 


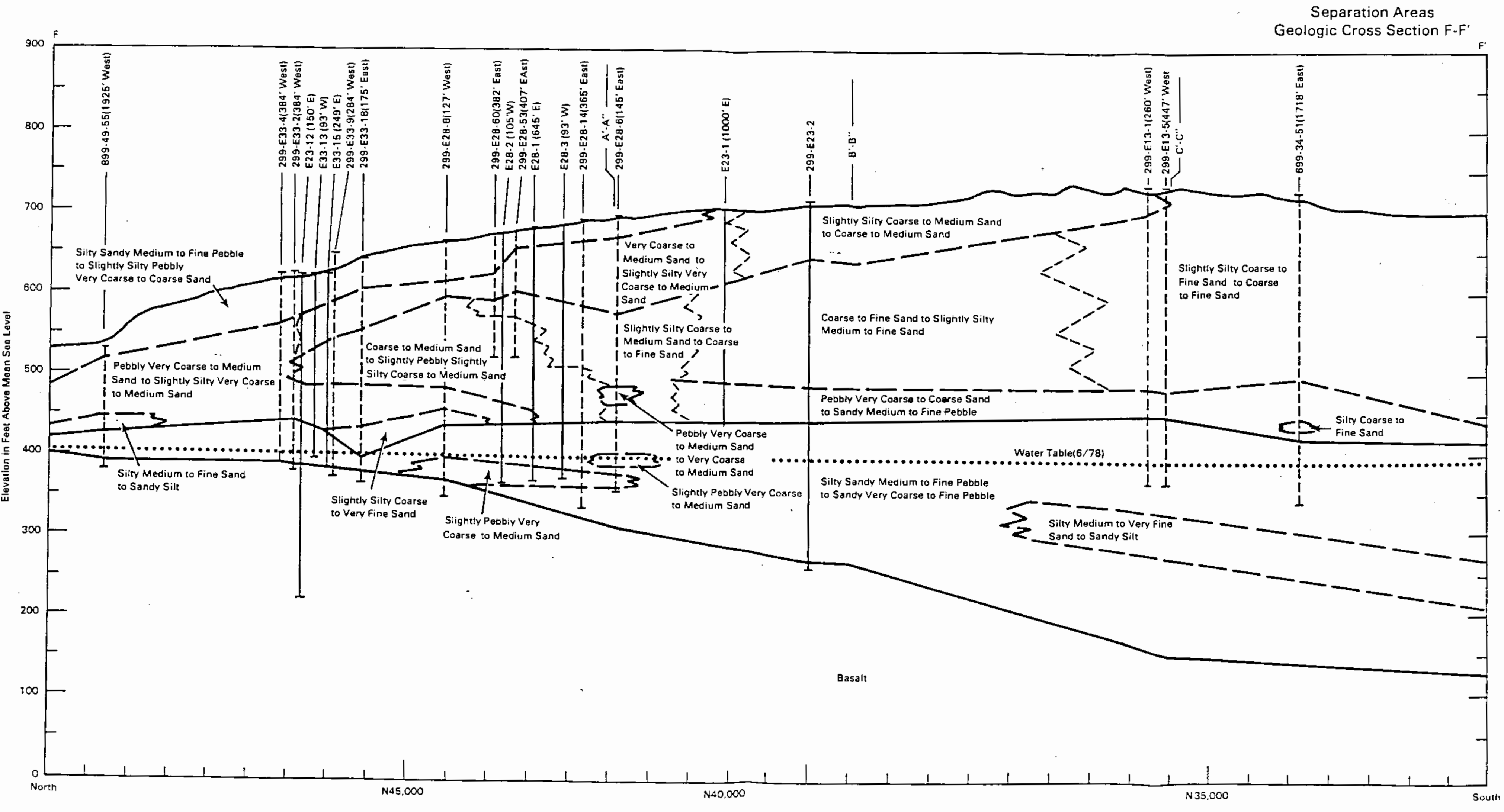


. . 
Separation Areas

Geologic Cross Secior

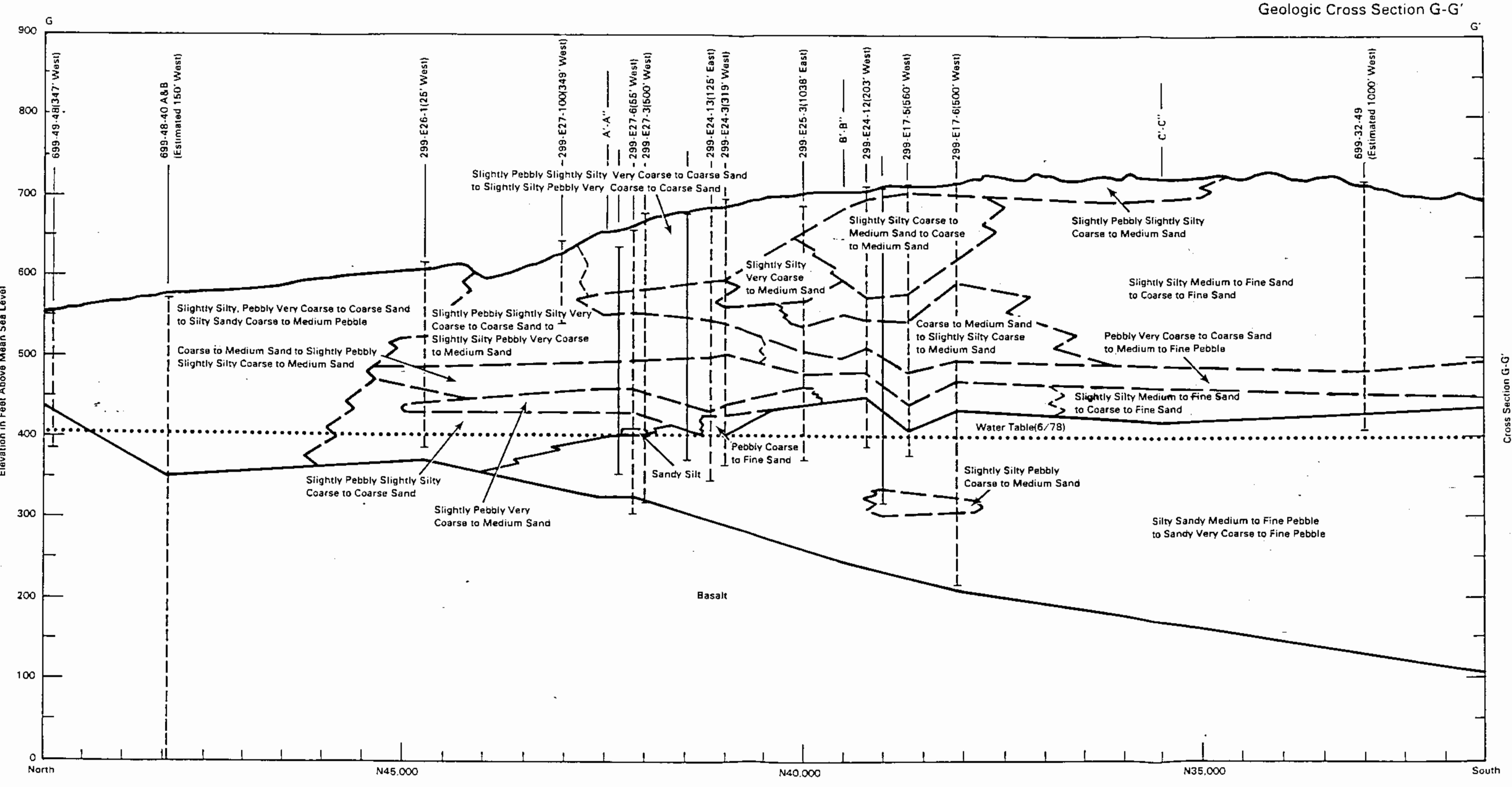





\section{Hanford Formation}

Surface and near-surface deposits are of unconsolidated sand and gravel of the Hanford formation. The thickness of the Hanford formation averages about $60 \mathrm{~m}$, but thins to approximately $10 \mathrm{~m}$ beneath Gable Mountain Pond. The Hanford formation can be broken down into three main textural units beneath the 200-East Area.

The lowermost unit is a pebbly, very coarse sand to sandy gravel that is relatively thin (approximately $10 \mathrm{~m}$ ) and lies directly on the middle Ringold. This unit is present mostly beneath the southern and eastern portions of the area, possibly extending to beneath B Pond.

The middle textural unit is a coarse-to-fine sand unit. This unit is the thickest and most extensive Hanford formation unit in the vicinity. It averages about $60 \mathrm{~m}$ thick and is present throughout the 200-East Area, except in the northeastern portion where a main channel appears to cut through the unit (Tallman et al. 1979). The unit has a wide variation of grain size, ranging from pebbly and very coarse-to-medium sand to a slightly silty medium-to-fine sand.

The uppemost unit is a fairly thin silty sandy gravel and occurs only in the northwestern portion of the 200-East Area. Hydrology of the Unconfined Aquifer

The unconfined aquifer beneath the Hanford Site is contained within the Ringold Formation and the overlying Hanford formation. The unconfined aquifer is affected by disposal of waste water to surface and subsurface disposal sites. The depth-to-ground water ranges from 180 to $310 \mathrm{ft}$ on the 200 Area Plateau. The bottom of the unconfined aquifer is the uppermost basalt surface or, in some areas, the clays of the lower Ringold Fomation. The thickness of the unconfined aquifer in the 200 Areas ranges from less than 50 to $200 \mathrm{ft}$. Beneath the unconfined aquifer is a confined aquifer system consisting of sedimentary interbeds or interflow zones that occur between dense basalt flows or flow units. 


\section{Recharge}

The sources of natural recharge to the unconfined aquifer are rainfall from areas of high relief to the west of the Hanford Site and the ephemeral streams, Cold Creek and Dry Creek. From the areas of recharge, the ground water flows downgradient and discharges into the Columbia River. This general flow pattern is modified by basalt outcrops and subcrops in the 200 Areas and by artificial recharge (Figure 14 ).

The unconfined aquifer beneath the 200 Areas receives artificial recharge from liquid disposal areas. Cooling water disposed to ponds has formed groundwater mounds beneath three high-volume disposal sites: U Pond in the 200-West Area, B Pond east of the 200-East Area, and Gable Mountain Pond north of the 200-East Area. The water table has risen approximately $65 \mathrm{ft}$ under $\mathrm{U}$ Pond and $30 \mathrm{ft}$ under B Pond compared with pre-Hanford conditions (Newcomb et al. 1972). During 1984, U Pond was deactivated and part of Gable Mountain Pond was backfilled in preparation for deactivation (Law and Schatz 1986).

\section{Effect of Artificial Recharge}

Response of the water table to actions similar to the deactivation of $U$ Pond can be expected in both Separation Areas. Planning is underway to greatly reduce the amount of process water disposed on the Hanford Site. Projections of the reductions range up to an $80 \%$ decrease in these disposals. Current projections of disposals indicate that water use would be reduced between the years 1995 and 2010. The results of this reduction in water use have been assessed using numerical modeling of steady-state flow in the groundwater flow system. The impact of such waste-water disposal changes would be major reductions in water levels, drying up the unconfined aquifer in the 200-East Area. This lowering of the water table would cause wells in both Separation Areas to go dry, cause changes in ground-water flow direction, and result in a reversal of the vertical gradient between the confined and unconfined ground-water systems in the vicinity of current major water disposal areas. 


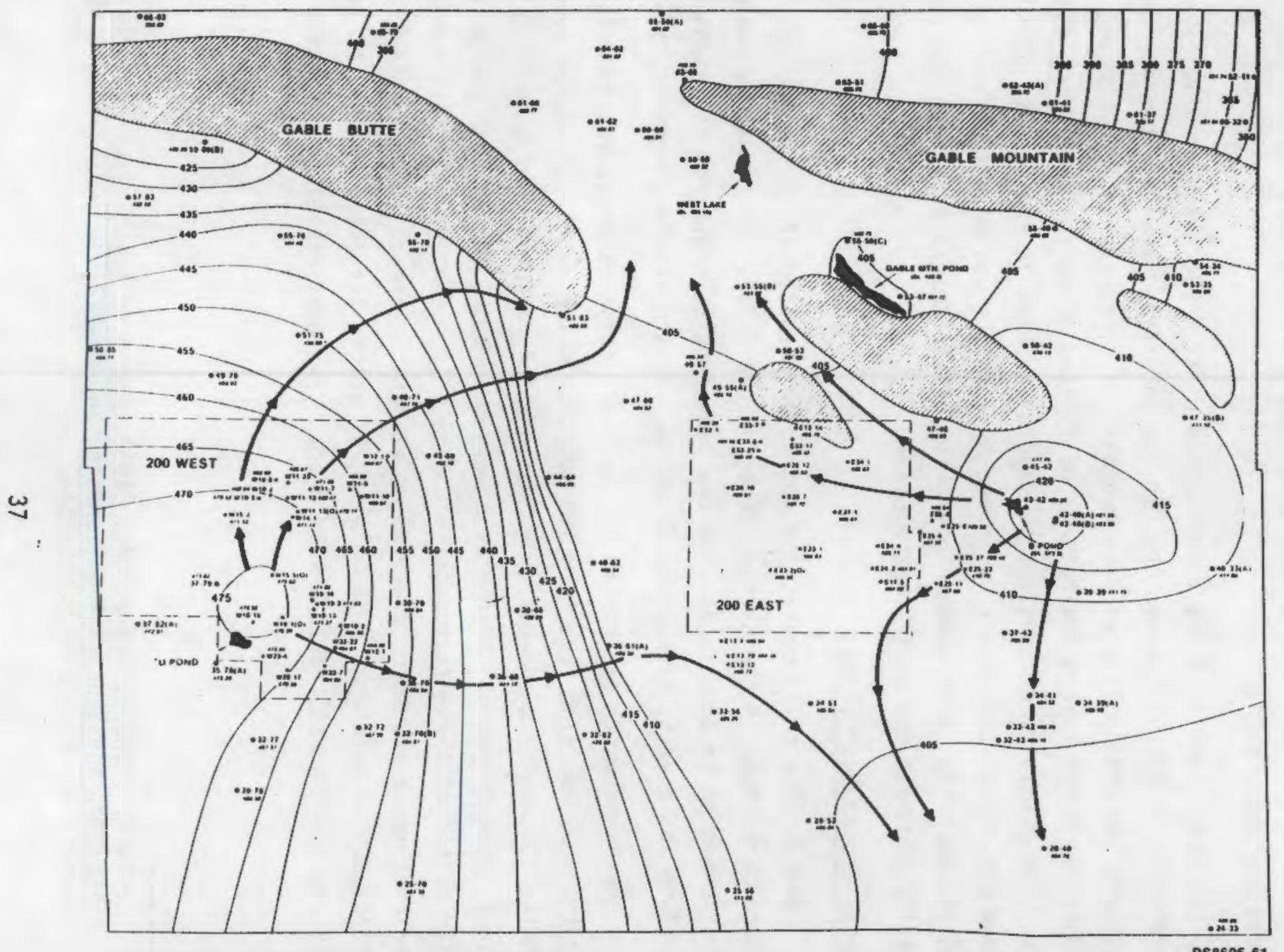

DECEMBER 1985

WATER-TMEUE CONTOUAS IN FEET NOOVE MEAN SEA LEVEL (n-WSL)

- FIVE-FOOT CONTOUA
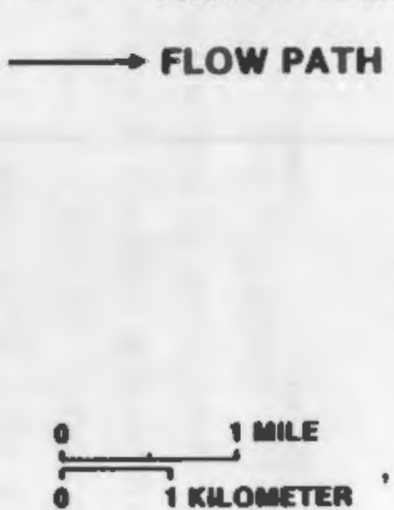

FIGURE 14. 200 Area Water Table Map Showing Direcitons of Ground-Water Flow 
In the 200-East Area, the projected $90 \%$ reduction in water disposal to $B$ Pond will rapidly affect underlying ground-water levels because the water table is within the more permeable Hanford formation sediments. Ringold Formation sediments are thin or absent in the area of the 200-East Area LLBG, and a lowering of the water table will also result in islands of basalt subcropping above the water table.

As water levels in the unconfined aquifer drop, the hydraulic head in the confined aquifer will exceed that in the unconfined aquifer, thereby further reducing the possibility of deep movement of contaminants. Completing monitoring wells in the basalt aquifers is of limited value for monitoring the LLBG under the predicted circumstances. Hydraulic head in the basalt aquifer is above the top of the basalt, as shown by existing wells, effectively eliminating the potential for downward migration of contaminants through the confining basalts and into the next lower aquifer.

Burial Ground Operations

Radioactive solid wastes are stored or disposed of in the 200 Area burial ground facilities in the Hanford Site for the USDOE. These wastes are stored or disposed of in accordance with the requirements contained in RHO-MA-222, "Hanford Solid Waste Packaging, Shipping, and Storage Requirements." (a)

Low-level waste is defined as any radioactive material intended for discarding that contains less than $100 \mathrm{nCi} / \mathrm{g}$ of waste matrix of radium sources, uranium-233 and/or alpha-emitting transuranium radionuclides with half-lives greater than 20 years. Transuranic wastes contain greater than $100 \mathrm{nCj} / \mathrm{g}$ of waste matrix of these radionuclides. The only hazardous materials permitted in low-level waste stored or disposed of at Hanford are co-contaminants (i.e., nonradioactive hazardous materials and/or wastes are not permitted to be mixed with low-level waste) or lead shielding. Low-level wastes co-contaminated with

(a) Rockwell 1Hanford Operations. 1983. Hanford Solid Waste Packaging, Shipping, and Storage Requirements. RHO-MA-222, Rev. 2, Rockwell Hanford Operations, Richland, Washington. 
hazardous materials are considered radioactive mixed wastes. Some contaminants received in solid radioactive waste in the past are listed below.

$\begin{array}{ll}\text { Asbestos } & \text { Polyurethane } \\ \text { Beryllium } & \text { Potassium Chloride } \\ \text { Caustic } & \text { Potassium Nitrate } \\ \text { Charcoal } & \text { Slaked Lime } \\ \text { Chromium } & \text { Sodium } \\ \text { Creosote } & \text { Sodium Chloride } \\ \text { Freon II } & \text { Sodium Fluoride } \\ \text { Graphite } & \text { Sodium Hydroxide } \\ \text { Hexanol } & \text { Sodium Nitrate } \\ \text { Lead } & \text { Sodium Nitrite } \\ \text { Lead Brick } & \text { Sulfuric Acid } \\ \text { Mercury } & \text { Toluene } \\ \text { Nitric Acid } & \text { Trichlorethene } \\ \text { Paint Thinner } & \text { Urlanium Hexaflouride } \\ \text { PCB, Oil } & \text { Xylene } \\ \text { Perchloroethylene } & \text { Toluene }\end{array}$

Solid low-level radioactive, transuranic, and radioactive mixed wastes have been stored or disposed of in burial grounds on the Hanford Site since the 1940s. Burial grounds addressed in this plan are those sites that have received radioactive mixed waste since November 1980 . The burial grounds addressed in this plan are all within the 200 Areas.

Only solid radioactive waste is accepted for disposal in the low-level burial grounds. Small quantities of radioactive waste containing free liquid organics are accepted for storage on a case-by-case basis in the low-level retrievable storage units. Transuranic wastes are also placed in retrievable storage units. Small quantities of low-level radioactive waste that may contain hazardous constituents (radioactive mixed wastes) are accepted for both disposal and storage at Hanford. To the extent practical, the various waste types are segregated into separate trenches within the burial grounds.

Low-level radioactive waste is packaged in a system of multiple barriers selected and specifically engineered to isolate the waste content from man and 
the environment. Packaging systems may include several plastic, metal, and glass containers, as well as absorbents in void spaces. The waste type may also be treated to provide additional barriers to the environment or make the waste more compatible with other barrier materials.

Each shipment of waste received at the LLBG and retrievable storage units must be accompanied by an accurate and complete "Solid Waste Burial Record Low Leve1," or "Solid Waste Storage Record - Transuranic." The waste generator is required to complete these forms and identify and quantify all hazardous constituents present. The waste generator also enters the burial compliance checksheet approval number on these forms.

Operations personnel perform radiological and visual inspection of waste package(s) and the accompanying documentation upon receipt of waste. If the waste and accompanying documentation are determined to be acceptable, the waste is stored or disposed of in the burial grounds.

Two types of trenches are used in the burial grounds. Vee trenches are normally dug $16 \mathrm{ft}$ deep with the bottom ranging from 0 to $16 \mathrm{ft}$ wide. Trench slopes range from 1-to-1 to 1-to-1 1/2. Waste placed into these trenches is backfilled with a minimum of $8 \mathrm{ft}$ of soil on a daily basis or as needed.

Wide-bottom or industrial trenches may be up to $50 \mathrm{ft}$ deep with the bottom ranging from 16 to over $100 \mathrm{ft}$ wide. Trench slopes are usually $11 / 2-$ to-1 to avoid cave-ins. If vehicular activity is required in the trench, the bottom of the trench is covered with several layers of crushed gravel. This layer also provides a base for stacking waste. All waste is either boxed, drummed, or self-contained (i.e., equipment). A wide-bottom trench is backfilled when approximately $100 \mathrm{ft}$ of stacked waste is in the trench.

Retrievable storage units are either placed in a Vee trench with a wide bottom or on asphalt pads. Fire retardant plywood is placed on the bottom of the Vee trench. Plywood is also placed between layers of waste and on top of the waste for both asphalt pads and Vee-type trenches. The waste and plywood is covered with a heavy plastic layer before backfilling all transuranic waste and low-flashpoint liquid organic waste stored in these units. 
Because of segregation of waste types and the logistics of burial ground operation, numerous trenches of different types are open at any given $t i m e$. Because of the placement of spoil piles, it is not possible to excavate adjacent trenches until an existing trench is filled. Since burial ground operations require land for spoil piles and a backup trench to be available for most types of waste trenches, large tracts of land are in use within the 200 Areas.

Approximately $700,000 \mathrm{ft}^{3}$ of solid waste per year are stored or disposed of on the Hanford Site. Approximately $20,000 \mathrm{ft}^{3}$ of waste per year is classed as transuranic waste. Radioactive mixed waste disposed of or stored at Hanford is currently estimated at approximately 14,000 to $35,000 \mathrm{ft}^{3} / \mathrm{yr}$. This estimate does not include the submarine compartment that is currently classed as by product waste. As radioactive mixed waste criteria are implemented and hazardous constituents in the waste are quantified accurately, the estimate regarding the quantity of radioactive mixed waste will be refined. 



\section{OBJECTIVES AND APPROACH}

To address the difficulty of monitoring individual waste trenches and burial grounds, the concept of Waste Management Areas (WMA) has been utilized. These WMA contain one or more of the LLBG. The WMA and the associated burial grounds are shown in Figures 15 and 16. A separate ground-water monitoring system is planned for each of the four WMA outlined in these Figures. Based on the size of the WMA, each of the monitoring systems is designed to exceed the minimum RCRA and WAC 173-303 requirements of one upgradient and three downgradient monitoring wells. The complex nature of the hydrologic system, with depths-to-water exceeding $200 \mathrm{ft}$ in the 200-west Area and $250 \mathrm{ft}$ in the 200East Area, has resulted in the systematic approach to the placement of monitoring wells described here. (Thirty-five wells are planned for installation during the first year of this effort. Additional wells may be drilled, as planned and appropriate, in subsequent years based on analysis from the initial well system).

\section{OBJECTIVES}

Five specific objectives must be met to achieve adequate characterization of the 200 Areas LLBG hydrogeology and geochemistry. These objectives are:

1. Develop a more complete picture of the hydrogeology of the Ringold Formation and glaciofluvial sediments in the area of the burial grounds.

2. Determine the variation in hydraulic potential with depth in the aquifer in the vicinity of the burial grounds.

3. Determine the range of hydraulic conductivity values for the glaciofluvial sediments and Ringold formation.

4. Determine storativity and effective porosity of the glaciofluvial sediments and Ringold formation. 


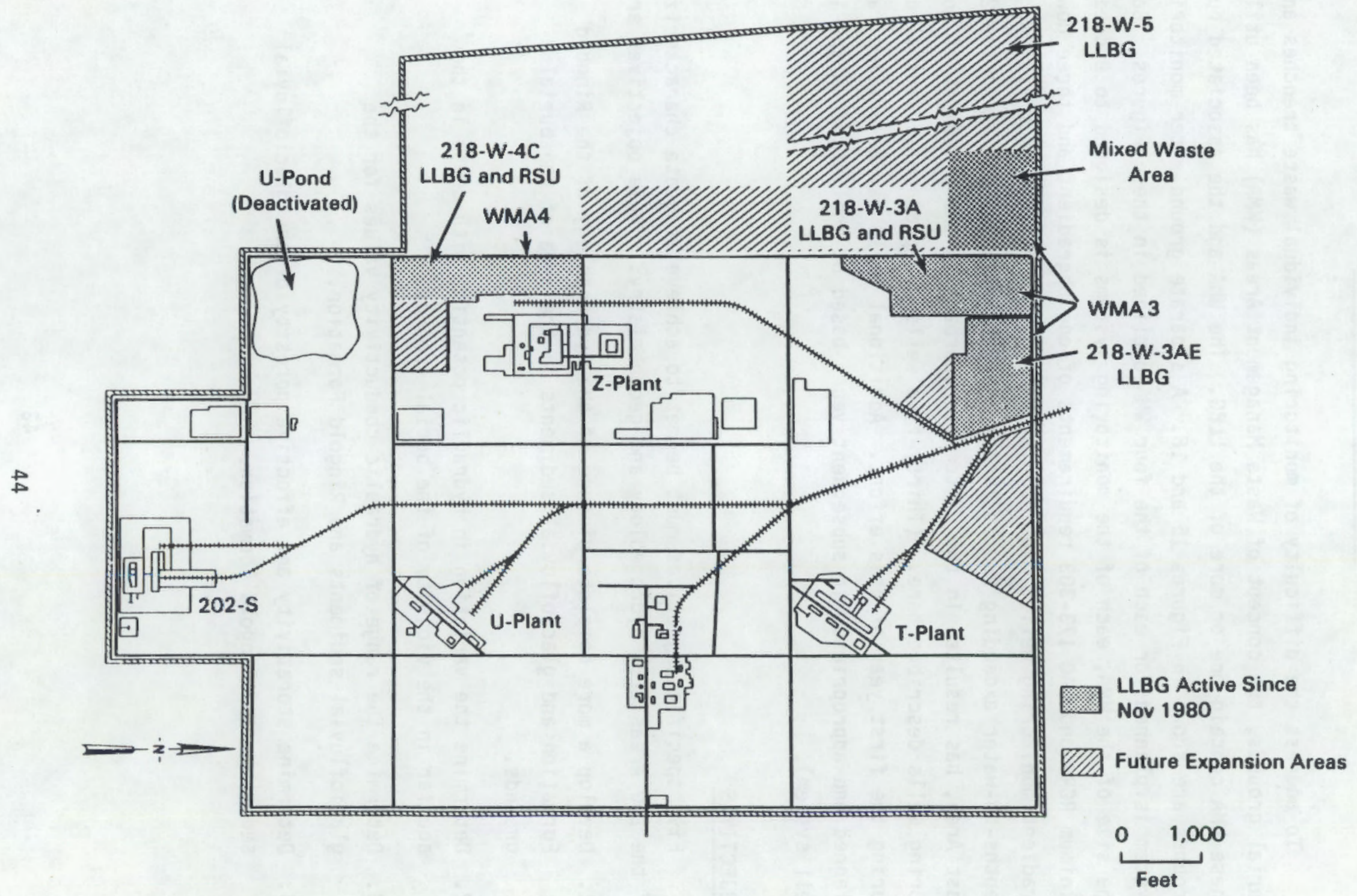

FIGURE 15. Location Map of Burial Grounds and Waste Management Areas in the 200-West Area 


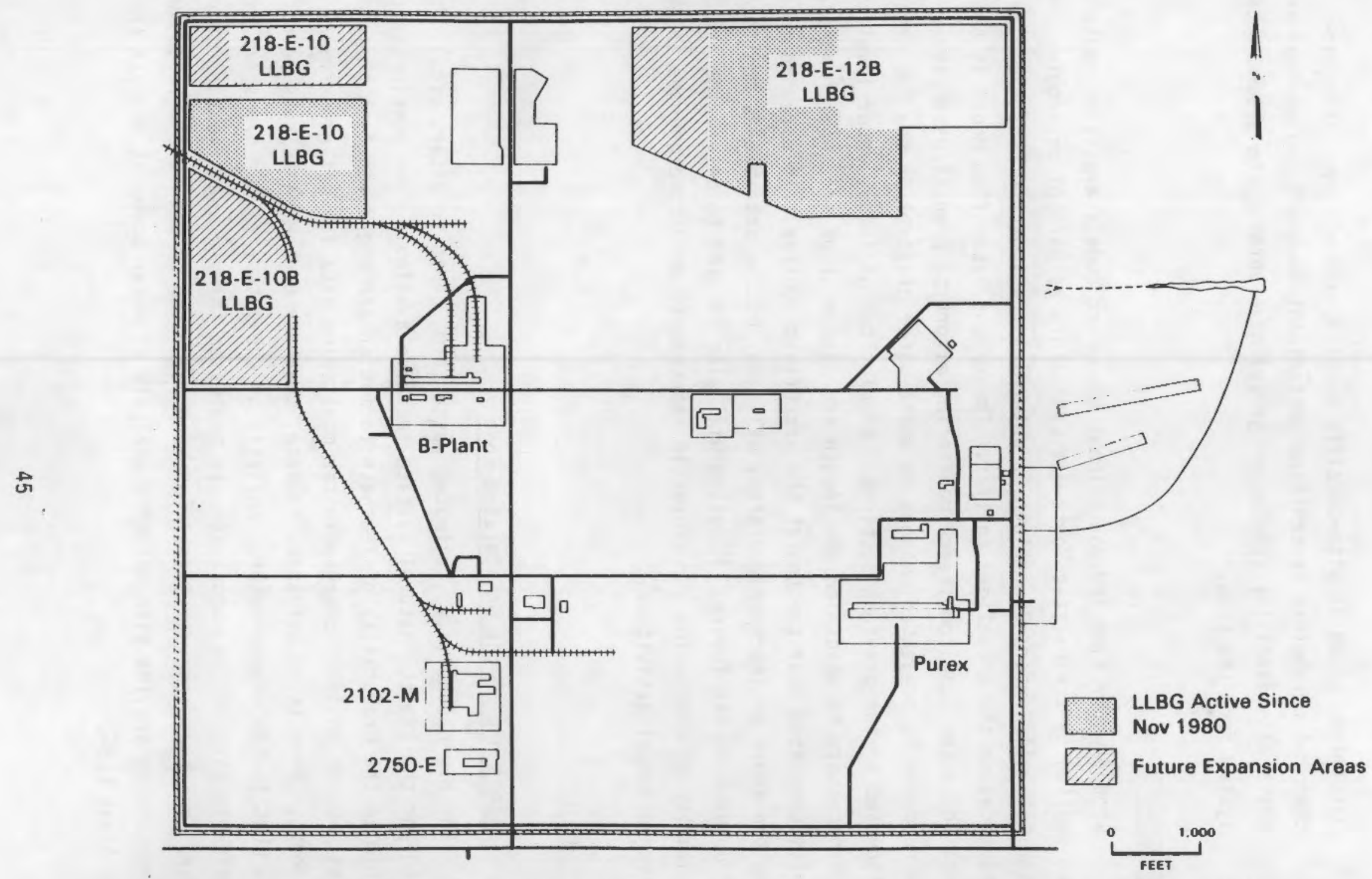

FIGURE 16. Location Map of Burial Grounds and Waste Management Areas in the 200-East Area 
5. Determine, based on site-specific sampling and analyses, the geochemical parameters controlling contaminant movement and whether or not contaminants (by species or group) have entered the ground-water system from the LLBG.

MODELING

Ground-water flow and contaminant transport models are being calibrated and applied by the Pacific Northwest Laboratory as part of an ongoing project with Rockwell Hanford Operations to determine the impact of waste management practices on the unconfined aquifer. The ground-water flow model is being applied to the LLBG compliance monitoring effort to predict water level changes in response to projected changes in waste-water disposal in the 200 Areas, as discussed in the previous sections. Predictions of future water level changes are necessary to determine the length and placement of screens for monitoring wells completed near the top of the unconfined aquifer. If screened intervals are too short or improperly placed, wells may become unusable as monitoring structures in the future. Modeling will also be used to assess the probable longevity of monitoring structures in response to predicted changes in wastewater disposal activities.

APPROACH

\section{Assessment of the Unsaturated Zone}

The dry nature (i.e., climate, waste form, depth-to-water, etc.) of the LLBG and the limited natural surface recharge available from precipitation minimize the probability of leachate fomation and migration from these facilities. Based on limited ground-water monitoring data for hazardous waste components, there is no evidence, to date, that any contaminants have moved from the LLBG to the ground water. Analys is of the potential for transport of contaminants through the vadose zone is addressed through specific aspects of this plan. Moisture studies similar to those described in Gee et al. (1985) will be conducted to provide site-specific analys is of water movement beneath the 200 Areas LLBG. 
Determination of the hydrology of the vadose zone is designed to develop the tools needed to adequately monitor the burial grounds so that contamination of the ground water does not occur. Specific data to be developed to characterize the vadose zone include moisture content, hydraulic conductivity, soil saturation curves, and moisture retention. Geochemical testing of the unsaturated soil materials will be carried out to ascertain the effects of the soil column on the potential movement of contaminants. Although these studies do not alter the need for active ground-water monitoring, they do provide a scientific basis for determining the level of monitoring that is needed to ensure detection of any migrating contaminants. Geochemical testing of the sediments with increasing depth will provide the data needed to assess the actual effects of individual waste disposal activities within the 200 Areas. Of important concern is the ability to segregate the effects of differing operations in the vicinity of the burial grounds. Samples will be selected for these analyses based on the geology of individual well bores. A maximum of 10 samples from any well bore will be analyzed. All samples will be retained, allowing for additional analyses at a later date should those analyses be found necessary. Mineralogical, chemical, and radiological testing of selected samples for the LLBG are necessary to assess the present extent and the future potential for contaminant migration. (See Appendix A for a review of chemical evaluations.) Analysis of the unsaturated zone sediments will be performed on uncontaminated samples to determine the baseline environmental conditions at the facilities, while similar analyses will be performed on sediment samples immediately downgradient of the buried waste to determine the presence, nature, and extent of any contamination that may have migrated from the LLBG.

The need to perform these detailed analyses of the unsaturated zone sediments in the vicinity of the LLBG is based on two factors. First, it is acknowledged that the ground water beneath the facilities to be monitored has been affected by liquid disposal activities in the current upgradient direction. Changing water levels beneath the burial grounds may have deposited contaminants above the present water table, complicating interpretation of ground-water monitoring data. Second, calculations performed in the Hanford Defense Waste Environmental Impact Statement (USDOE 1986) suggest that moisture 
and contaminant travel times in the unsaturated zone from solid waste burial grounds would likely exceed 50 years. Since none of the burial grounds have been in existence for that length of time, it is essential to determine the extent of any contamination in the unsaturated zone.

These factors, when taken together, support the need for a thorough characterization of the unsaturated zone. This effort will not only ensure that the site is in compliance, but also will allow prediction of potential impacts of these facilities on the ground water.

Wells drilled as ground-water monitoring wells will provide the characterization data on the vadose zone. Each of the WMA in the 200-West Area will have upgradient and downgradient deep monitoring wells to characterize the hydrogeology at depth and to assess the hydraulic potential and quality of ground water near the base of the unconfined aquifer. Adjacent to these deep wells will be shallower wells that penetrate the upper portion of the unconfined aquifer. In the 200-East Area, the limited thickness of the saturated zone makes the drilling of deep and shallow wells unnecessary. In this area all wells will be drilled to the top of the basalt. Characterization of the saturated zone beneath the burial grounds will be accomplished through the collection and analysis of geologic samples. Analysis of these samples will include grain-size distribution, mineralogy, and cation exchange capacity. Determination of the hydrologic properties will be accomplished through aquifer tests. Core samples of confining beds will be collected using Shelby Tube or split-spoon samples. These core samples will be analyzed in the laboratory to ascertain vertical hydraulic conductivity.

Monitoring of the ground water will be initiated in the first calendar quarter following completion of individual monitoring wells, and will be 
quarterly thereafter. Samples from these wells will be collected using established field and Quality Assurance/Control (QA/QC) procedures. Specific analyses to be performed will include:

$\begin{array}{lll}\text { Ammonium Ion } & \text { Iron } & \text { Silver } \\ \text { Arsenic } & \text { Lindane } & \text { Selenium } \\ \text { Barium } & \text { Lead } & \text { Sodium } \\ \text { Cadmium } & \text { Magnesium } & \text { Sulfate } \\ \text { Calcium } & \text { Manganese } & \text { Specific Conductance } \\ \text { Chloride } & \text { Mercury } & \text { Total Carbon } \\ \text { Chromium } & \text { Methoxychlor } & \text { Total Dissolved Solids } \\ \text { Coliform Bacteria } & \text { Nitrate } & \text { Total Organic Carbon (TOC) } \\ \text { Endrin } & \text { Phenols } & \text { Total Organic Halogen (TOX) } \\ \text { Fluoride } & \text { pH } & \text { Toxaphene } \\ \text { Gross Alpha } & \text { Potassium } & 2,4-0 \\ \text { Gross Beta } & \text { Radium } & 2,4,5-T P ~ S i l v e x\end{array}$

Site-specific parameters will be analyzed. Detemination of specific parameters will be acomplished through disposal records for individual WMA. Disposal records are contained in the Part B permit application.

Samples will be collected and analyzed quarterly; replicate samples as specified in 40 CFR 265.93 (c) will be analyzed to detemine background values. 

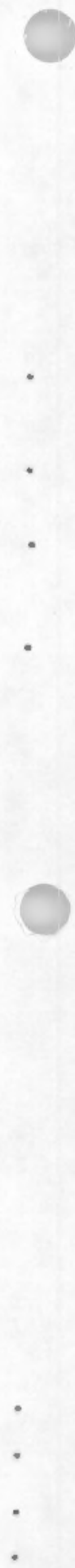

- 


\section{COMPLIANCE IMPLEMENTATION PLAN AND SCHEDULE}

The specific objectives will be accomplished through a series of interrelated tasks that include: installing monitoring wells and well pairs, analyzing sediments of the vadose zone, performing aquifer tests, taking timeequivalent water level measurements, conducting borehole geophysical logging, collecting and analyzing environmental samples, performing statistical evaluation of data, and integrating old and new data for refinement of the conceptual and numerical models. The details of the planned approach to meet each of the specific objectives are discussed in the following paragraphs.

\section{PLAN IMPLEMENTATION}

The first year's effort addresses the five specific objectives mentioned in the previous section, and in addition provides an independent monitoring system for each of the LLBG. The work is described in the sequence of performance.

\section{Well Installation}

The first activity will be the installation of 35 monitoring wells that include 27 single wells and 4 paired well clusters. The paired well clusters consist of two wells, 25 to $50 \mathrm{ft}$ apart, one penetrating the upper saturated portion of the aquifer and one penetrating to the base of the aquifer. The aquifer base is defined as the top of the lower Ringold Formation, where present, or the top of the basalt where the lower Ringold is missing.

Tentative locations for characterization/monitoring wells are shown in Figures 17 and 18. The selection of these locations is tied to the desire to adequately characterize the hydrogeologic system of the 200-West and 200-East Areas LLBG while simultaneously establishing independent ground-water monitoring systems for each of the WMA. For each of the WMA, a minimum of two upgradient wells has been placed to provide background water-quality data and to statistically validate the data. Also included in the 200 -West Area are deep wells, both up- and downgradient. These wells will provide hydrogeologic data on the distribution and continuity of hydrostratigraphic units to the base 


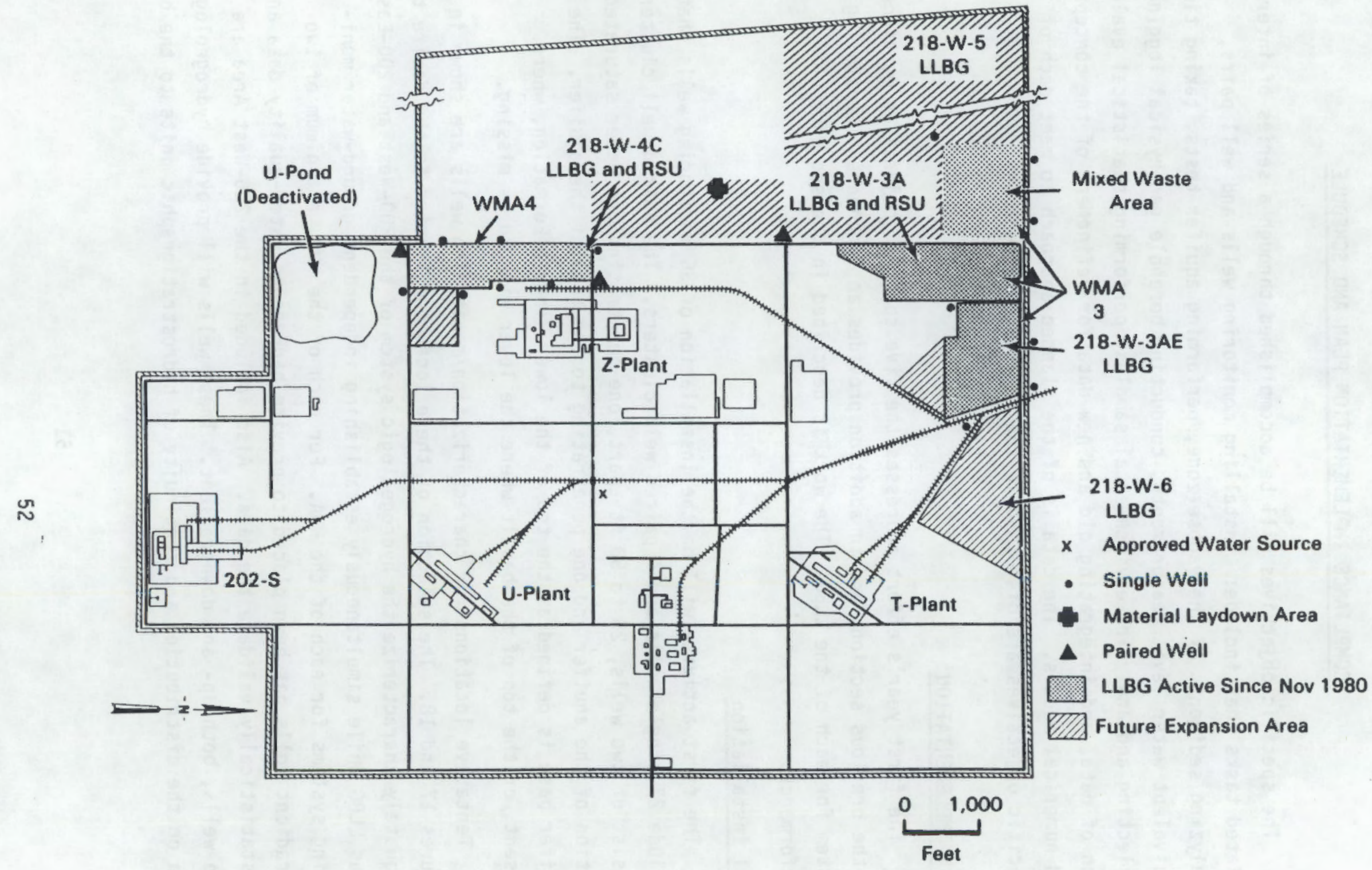

FIGURE 17. Location Map of Planned Clusters and Single Monitoring Wells in the 200-West Area 


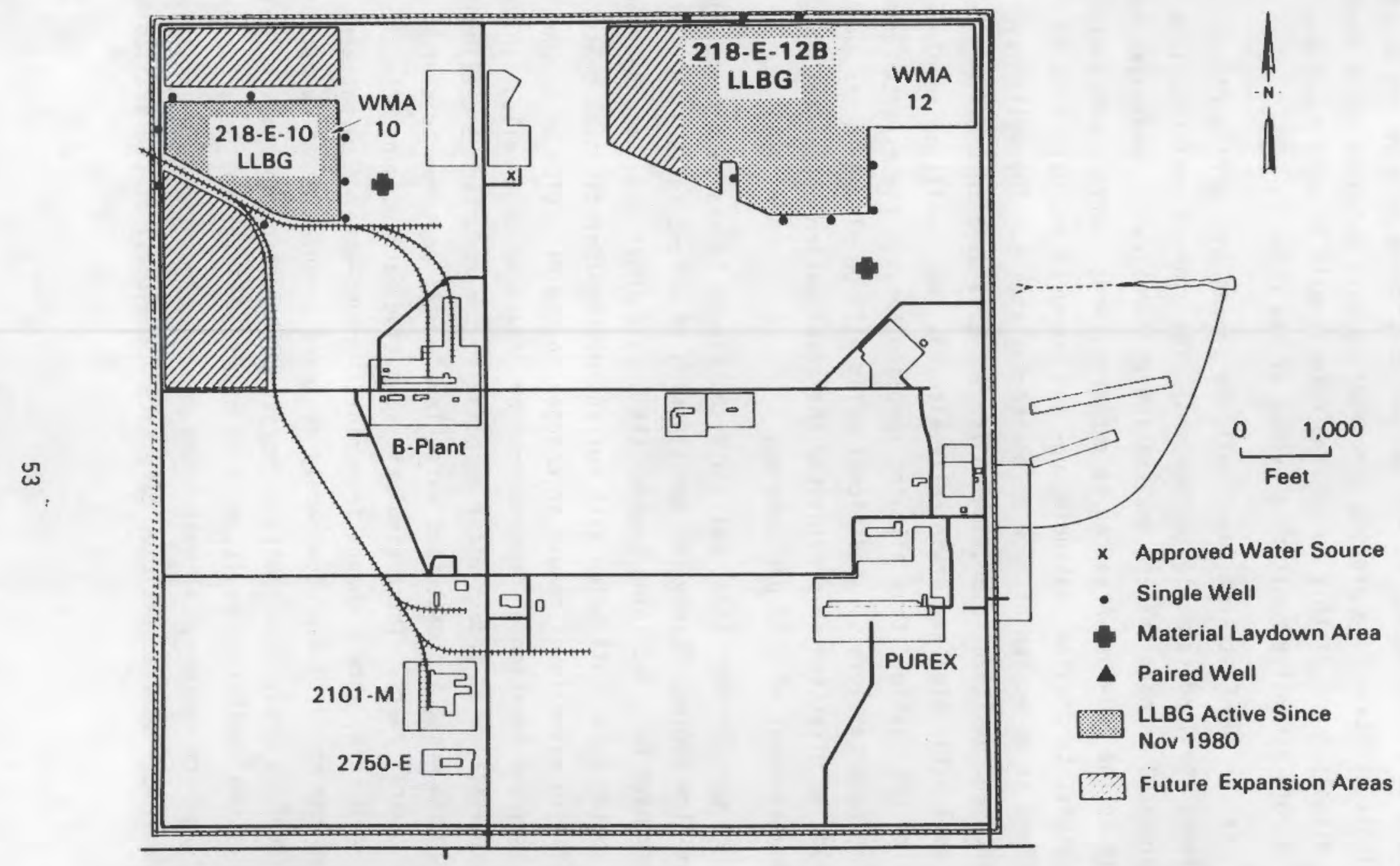

FIGURE 18. Location Map of Planned Single Monitoring Wells in the 200-East Area 
of the unconfined aquifer system. Downgradient wells have been tentatively located on approximately $600-\mathrm{ft}$ centers to provide data on the continuity of geologic strata and to provide a monitoring well network. Data derived from the establishment of this monitoring network will be used to assess the need for a more extensive monitoring system of the LLBG.

In the 200-East Area, wells will be placed in a configuration that reflects the long-term flow directions. The planned well locations have been determined, in part through application of numerical ground-water models. Wells in the 200-East Area can be expected, under current waste-water disposal practices, to provide continuing up- and downgradient data with no major disruptions in direction of flow or monitoring status. The wells have been located and designed to provide monitoring data even in the event that water disposal activities are drastically altered. Wells will be completed to the base of the aquifer, thus allowing sampling through the expected period of declining water levels. Additional wells will be placed in the current upgradient direction to provide the characterization data necessary for longterm assessment of LLBG performance.

In the 200-West Area, wells will be placed to assess a changing groundwater flow regime. Since the deactivation of $U$ Pond in 1984, ground-water levels have been declining beneath the pond's location. Ground-water levels are coming into equilibrium with current waste-water disposal practices. These changes in water level result in changes in the direction of ground-water flow, and thus the location of "upgradient" or "downgradient" wells. Initial numerical simulations of ground-water response to the reduction and elimination of the $U$ Pond mound indicate that water levels will continue to change over the next several years. These simulations, taking into account only the elimination of $U$ Pond, show a change from radial ground-water flow pattern centered around the mound to a predominately eastward ground-water flow pattern toward the 200-East Area. Placement, in horizontal location and in vertical completion of the monitoring wells, will be based on historical data gathered through the long-term radiological monitoring program, recent characterization efforts, and numerical simulations that take into account all of the available data. 
To develop a more complete picture of the 200-West Area hydrogeology, the first monitoring wells to be constructed will be the deeper wells for WMA 3 and WMA 4. The wells will be geologically logged and samples will be analyzed to characterize the geology. These wells will be initially developed in the upper portions of the unconfined aquifer in either the glaciofluvial sediments or the Ringold Formation. The paired shallow wells associated with each deep well will then be drilled and temporarily completed at the final depth with well screens. Hydraulic properties of the upper aquifer will then be determined through multiple well pumping tests. Following completion of the hydraulic testing of the shallow well, drilling will recommence on the deep well. Water level measurements will be taken daily during drilling of the deep well to determine the distribution of hydraulic head with depth. The deep well will be completed at the bottom of the aquifer and hydraulically tested to determine aquifer characteristics at depth (transmissivity). During this testing of the deep well, measurements in adjacent shallow wells will be taken in an attempt to estimate vertical hydraulic conductivity.

In the 200-East Area, wells will be drilled sequentially along the northern boundary of the WMAs, providing a cross section of the hydrogeologic regime. Following completion of those wells, the remaining wells will be constructed to provide the areal distribution of hydrostratigraphic units necessary to fully describe the area of interest. All of the wells are anticipated to be completed as fully penetrating wells, thus supplying a complete picture of the hydrogeologic system.

All planned wells will be installed using cable tool or air rotary methods. Each well will consist of an artificially sand-packed, stainlesssteel well screen with a stainless-steel casing (Figure 19). The finished inside diameter of the wells will be nominally $4 \mathrm{in}$. Screened intervals will typically be 10 to $20 \mathrm{ft}$, but the exact length of the screen will depend on the thickness of the interval of interest and numerical analysis of expected water level response to changing waste-water disposal practices. Drilling equipment, casings, and screens will be steam-cleaned prior to use and all construction materials kept off the ground. Following completion, all wells will be 


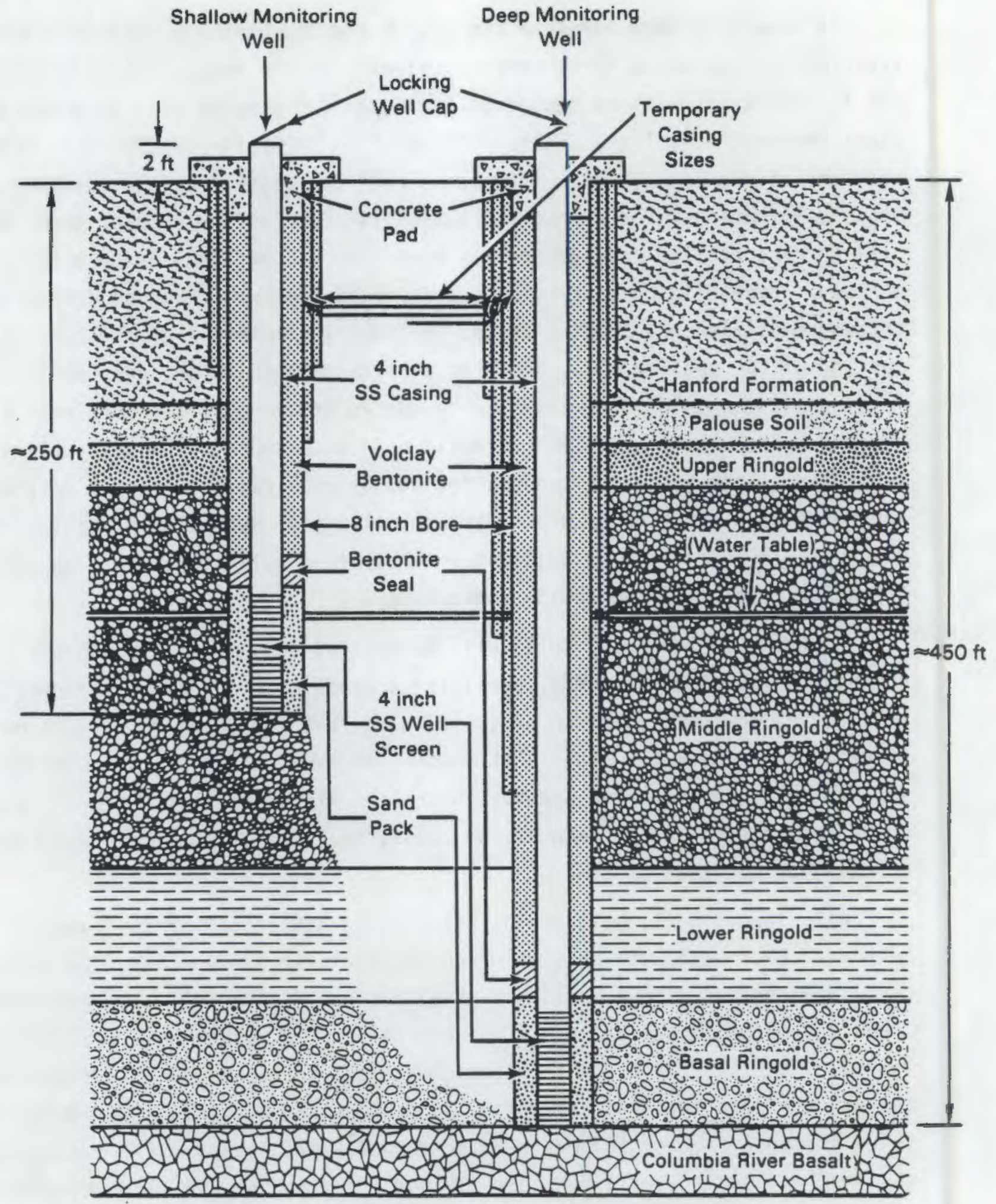

FIGURE 19. Planned Construction of Monitoring Wells 
developed with a bailer and/or pump. Borehole geophysical logs will be made for each well upon reaching final depth and after final completion. A geologist will be present during well drilling to examine the materials penetrated, prepare geologic logs, oversee the drilling activities, and revise well design if needed.

Upon completion of the entire drilling effort, each of the new wells will be surveyed to obtain both the exact location coordinates and the elevation of the top of the casing for collecting hydraulic-head data. The shallow gradients evident in the 200-East Area, based on past water level measurements, require that this surveying be accomplished to $\pm 0.01 \mathrm{ft}$. All wells will be pemanent ly marked with coordinates and elevation.

Sample Collection and Analysis

During cable-tool drilling, samples will be collected of both the sediments and the water. Sediment samples will be collected using a drive barrel (where boulders do not interfere) every $5 \mathrm{ft}$ and at changes in lithology. In cases where the drive barrel cannot be used, the samples will be taken with the bailer. Samples of confining bed materials, where encountered, will be taken using split-spoon or Shelby tube methods. No sampling is anticipated from planned rotary drilled holes; the proximity of these holes to an adjacent cable-tool drilled hole makes this sampling redundant, and the method itself limits the usefulness of samples that would be collected.

Laboratory tests to be conducted on selected samples will inciude: 1) a permeameter test to determine hydraulic conductivity; 2) mineralogy, i.e., identification; 3) sieve analysis for particle size distribution; 4) soil moisture content; 5) moisture retention; and 6) geochenical tests. Water samples taken during drilling will be analyzed for $\mathrm{pH}$, temperature, conductivity, and possibly other selected parameters. Data obtained from these soil and water samples will be used to help determine vertical and horizontal distribution of any contaminants encountered. 
Water Level Measurements

8elow the water table, water level measurements will be taken at the beginning of each drilling shift. Bafler tests will be used during drilling as a preliminary indication of aquifer perfomance.

\section{Well Specifications}

An engineering study, addressing the variables associated with well drilling activities on the Hanford Site, has been prepared. As a result of this study (see Appendix 8), a set of well drilling specifications has been developed (see Appendix C). Materials used in construction of the monitoring wells will be made of Type 304 stainless steel.

All new wells will be drilled a minimum of $8 \mathrm{in}$. in diameter to facilitate aquifer tests for determining aquifer hydraulic characteristics. A total of 35 aquifer tests will be performed (one for each well), lasting approximately $16 \mathrm{hr}$ ( $8 \mathrm{hr}$ of pumping and $8 \mathrm{hr}$ of recovery). The discharge rate and probable duration of each test will be determined by preliminary yield-tests during well development and the bailer tests performed during drilling. Based on experience from other tests on the Hanford Site, it is anticipated that sufficient drawdown will occur at a maximum discharge rate of $150 \mathrm{gpm}$. It is likely that the duration of aquifer tests will vary depending on data evaluated during the test. Storativity will be determined by testing of each of the 4 well pairs.

\section{WATER-QUALITY MONITORING}

Monitoring of the ground-water quality will commence in the first quarter of the year following completion of individual wells. Water samples will be collected according to the established procedures. Water level measurements will be taken before sampling, and the wells will be purged according to the borehole volume removal and/or indicator parameter stabilization procedure. Samples will be collected using dedicated sampling pumps appropriate for the analyses to be conducted. Samples to be analyzed for metals will be split into two aliquots-one to be filtered and analyzed for dissolved metals, and one to be nonfiltered and analyzed for total recoverable metals. 
Samples will be sealed and transported to the laboratory using the established Chain-of-Custody procedures (see Appendix 0 ).

The QA/QC procedures will be those described in Appendix $E$ and the current ground-water monitoring plan. Methods for sample analysis and sample preservation are described in Appendix F.

\section{FUTURE PLANS}

Efforts similar to those in the plan described above may be necessary in subsequent years. Based upon information gathered during the first year of effort, plans may be developed and negotiated with the Washington State Department of Ecology and additional efforts carried out, as necessary. Detailed plans for future activities will be developed at that time.

\section{SCHEDULE}

Drilling of the necessary characterization/monitoring wells is anticipated to commence in March 1987. The magnitude of the planned effort, an estimated $11,000 \mathrm{ft}$ of borehole, requires that specific, federally mandated procedures be followed in the design and awarding of contracts. Estimates on the rate of completion of individual wells have been made. The resulting time schedule (Figure 20 ), is representative of those estimates.

The assumptions used in developing the schedule estimate are as follows:

- Sufficient drilling machines are available for the entire effort.

- Cable-tool drilling will be used to drill all nonpaired shallow wells.

- Rotary drilling will be used to drill all shallow paired wells.

- Cable-tool drilling will be used on all deep wells.

- The cable-tool drilling rate is $15 \mathrm{ft} /$ day $(8 \mathrm{hr})$.

- The rotary drilling rate is $60 \mathrm{ft} /$ day $(8 \mathrm{hr})$. 


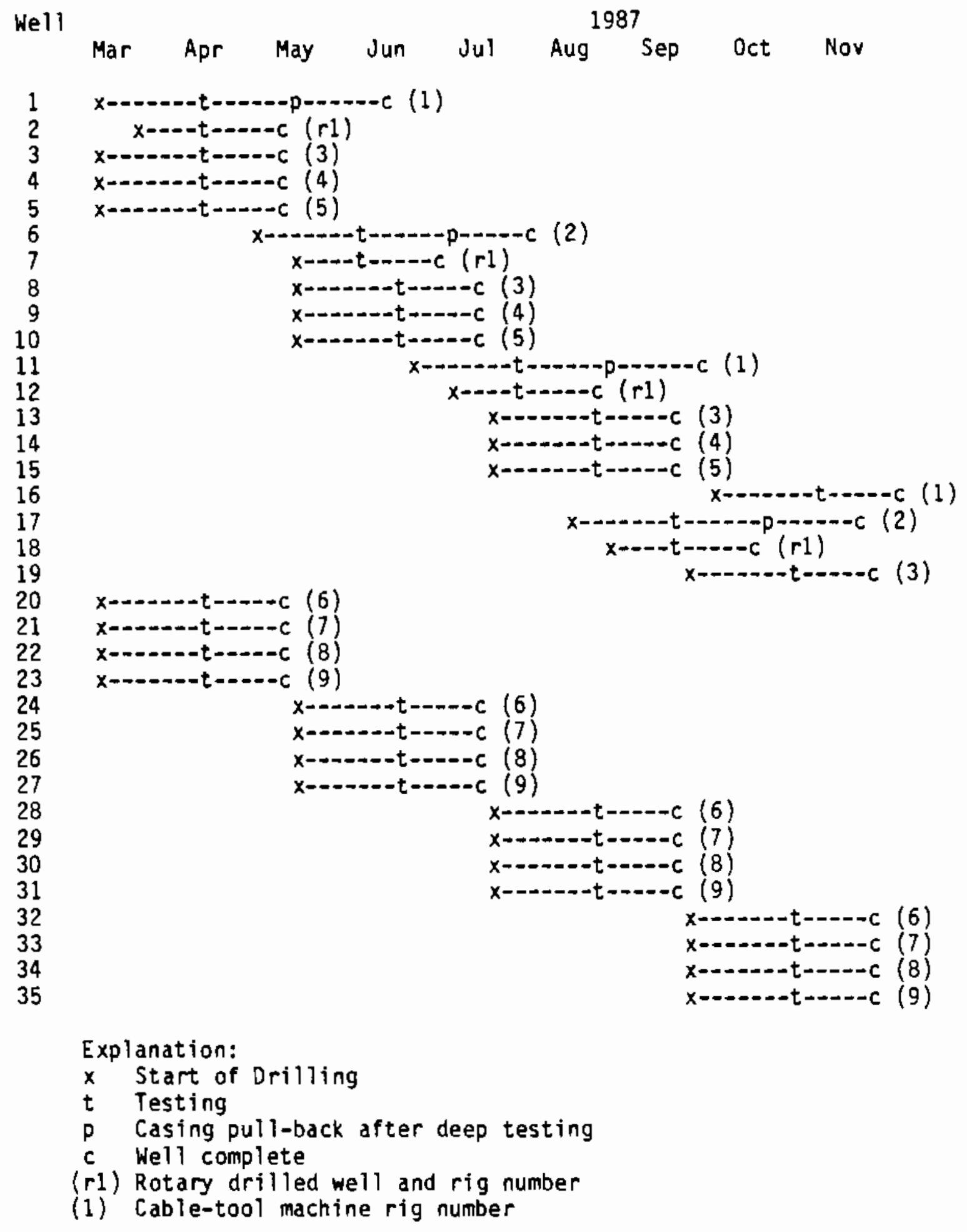

FIGURE 20. Well Completion Schedule 
- Four cable-tool machines will be available at all times for both the 200-West and 200-East Areas. In addition, one cable-tool machine will be available for transfer between areas.

- One rotary rig wi11 be available for the 200-West Area.

\section{REPORTING}

Interim reports on the results of the characterization work will be produced quarterly during the effort. A final report will be compiled upon completion of data analysis. This report will be more comprehensive than the interim reports, and will include results of all tests and modeling. In general, each report will contain: 1) narrative descriptions of the local geologic units and ground-water flow; 2) geologic cross sections; 3) water table maps; 4) geologic and drilling logs; 5) results of the various tests conducted; 6) as-buitt drawings of wells; and 7) where appropriate, recommendations concerning future drilling and/or sampling and analysis plans, testing, and modeling.

A report on the analytical results obtained under the extended monitoring program will be provided. This report will be produced when sufficient data are available. 



\section{REFERENCES}

Black, R. F. 1979. Clastic Dikes of the Pasco Basin, Southeastern Washington. RHO-8wi-C-64, Rockwell Hanford Operations, Richland, Washington.

Brown, D. J. 1959. "Correlation of Sediments Overlying the Columbia River Basalt in Souteastern Washington." HW-SA-3343A, Hanford Laboratories, General Electric Company, Richiand, Washington.

Brown, D. J. 1960. An Eolian Deposit 8eneath 200-West Area. HW67549, Hanford Laboratories, General Electric Company, Richland, Washington.

Fecht, K. R. 1978. Geology of the Gable Mountain-Gable Butte Area. RHD-BWILD-5, Rockwell Hanford Operations, Richland, Washington.

Gee, G. W., P. R. Heller, and D. A. Myers. 1985. Moisture and Textural Variations in Unsaturated Soils/Sediments Mear the Hanford Wye Barricade. PNL-5377, Pacific Northwest Laboratory, Richland, Washington.

Gephart, R. E., R. C. Arnett, R. G. Baca, L. S. Leonhart, and F. A. Spane, Jr. 1979. Hydrologic Studies Within the Columbia Plateau, Washington: An Integration of Current Knowledge. RHO-BWI-ST-5, RockweT7 Hanford Operations, Richland, Washington.

Graham, M. J. 1981. "The Radionuclide Ground-Water Monitoring Program for the Separations Area, Hanford Site, Washington State." Groundwater Monitoring Review 1(2):52-56.

Graham, M. J., M. D. Hall, S. R. Strait, and W. R. Brown. 1981. Hydrology of the Separations Area. RHO-ST-42, Rockwell Hanford Operations, Richiand, washington.

Graham, M. J., G. V. Last, and K. R. Fecht. 1984. An Analys is of Aquifer Intercommunication in the B-Pond/Gable Mountain Pond Area, Hanford Site. RHO-RE-ST-12, Rockwell Hanford Operations, Richland, Washington.

Law, A. G., and A. L. Schatz. 1986. Results of the Separations Area GroundWater Monitoring Network for 1985. RHO-RE-SR-86-24-P, Rockwell Hanford Operations, Richland, Washington.

Ledgerwood, R. K., and R. A. Deju. 1976. "Hydrogeology of the Uppermost Confined Aquifers Underlying the Hanford Reservation." ARH-SA-253, Atlantic Richfield Hanford Company, Richland, Washington.

Myers, C. W./S. M. Price, and J. A. Caggiano, M. P. Cochran, W. J. Czimer, N. J. Davidson, R. C. Edwards, K. R. Fecht, G. E. Holmes, M. G. Jones, J. R. Kunk, R. D. Landon, R. K. Ledgerwood, J. T. Lillie, P. E. Long, T. H. Mitchell, E. H. Price, S. P. Reidel, and A. M. Tallman. 1979. Geologic Studies of the Columbia Plateau: A Status Report. RHO-BWI-ST-4, Rockwell Hanford Operations, Richland, Washington. 
Myers, C. W. and S. M. Price. 1981. Subsurface Geology of the Cold Creek Syncline. RHO-BWI-ST-14, Rockwell Hanford Operations, Richland, Washington.

Newcomb, , R. C., J. R. Strand, and F. J. Frank. 1972. "Geology and GroundWater Characteristics of the Hanford Reservation of the U.S. Atomic Energy Commission, Washington." Professional Paper 717, U.S. Geological Survey, Washington, D.C.

Swanson, D. A., T. L. Wright, and I. Ziety. 1979. Aeromagnetic Map and Geologic Interpretation of the West-Central Columbia Plateau, Washington and Adjacent Oregon. MAPGP-917, U.S. Geologic Survey, Washington, D.C.

Tallman, A. M., K. R. Fecht, M. C. Marratt, and G. V. Last. 1979. Geology of the Separations Areas Hanford Site, South-Central Washington. RHO-ST-23, Rockwell Hanford Operations, Richland, Washington.

U.S. Department of Energy (USDOE). 1986. Draft Environmental Impact Statement: Disposal of Hanford Defense Wastes. DOE/EIS-0113, U.S. Department of Energy, Washington, D.C. 


\section{APPENDIX A}

CHEMICAL EVALUATION OF THE UNSATURATED ZONE 
CHEMICAL EVALUATION OF THE UNSATURATED ZONE

Chemical evaluation of the unsaturated zone beneath the 200 Areas solid waste burial grounds will be performed to meet three general requirements. These requirements are:

1. to develop a sound technical baseline

2. to comply with monitoring requirements of the Resource Conservation and Recovery Act

3. to develop the release and transport information required to assess contaminant transport from solid waste burial sites.

TECHNICAL BASELINE

Chemical analysis to establish a sound technical baseline will include mineralogical and total elemental analysis of sediments within the unsaturated zone. Mineralogical analysis will be used to establish the composition of the sedimentary units beneath the low-level waste burial grounds (LLBG) and determine if leachates have chemically altered the subsurface sediments beneath the sites. Total elemental analysis will be performed to determine the chemical composition and the levels of available trace elements in both unaffected and potentially contaminated sediments. The method of analysis and corresponding references for each method are shown in Table A.l.

\section{TABLE A.1. Sediment Chemical Analysis}

$\begin{array}{ll}\frac{\text { Methods of Analysis }}{\text { Mineralogical Analysis by X-Ray }} & \text { Reference } \\ \text { Diffraction } & \text { Black et al. 1965a } \\ \begin{array}{l}\text { Total Elemental Analysis by X-Ray } \\ \text { Fluorescence and/or Total Fusion, }\end{array} & \text { Black et al. 1965b } \\ \text { dissolution and Inductively- } & \\ \text { coupled plasma emission spectroscopy. } & \end{array}$


Table A.2 lists the elements analyzed for by the $X$-ray Fluorescence and total fusion methods.

IABLE A.2. Chemicals Measured in Total Elemental Analysis

\begin{tabular}{|c|c|c|c|}
\hline Constituent & Method & Constituent & Method \\
\hline $\mathrm{Al}_{2} \mathrm{O}_{3}$ & $\mathrm{ICP}$ & $\mathrm{CaO}$ & XRF \\
\hline $\mathrm{SiO}_{2}$ & $I C P$ & $\mathrm{Fe}_{2} \mathrm{O}_{3}$ & Ejther \\
\hline $\mathrm{Na}_{2} \mathrm{O}$ & $I C P$ & $\mathrm{MgO}$ & ICP \\
\hline $\mathrm{TiO}_{2}$ & XRF & $\mathrm{PO}_{4}$ & Either \\
\hline $\mathrm{B}_{2} \mathrm{O}_{3}$ & ICP & $\mathrm{BaO}$ & Either \\
\hline $\mathrm{CuO}$ & Either & $\mathrm{Li}_{2} \mathrm{O}$ & $I C P$ \\
\hline $\mathrm{MnO}_{2}$ & Either & $S r 0$ & Either \\
\hline $\mathrm{ZrO}_{2}$ & Either & $\ln 0$ & $X R F$ \\
\hline $\mathrm{K}_{2} \mathrm{O}$ & $X R F$ & $\mathrm{~V}_{2} \mathrm{O}_{5}$ & XRF \\
\hline $\mathrm{Cr}$ & XRF & $\mathrm{Ni}$ & $X R F$ \\
\hline Ga & XRF & $\mathrm{Se}$ & XRF \\
\hline $\mathrm{Pb}$ & XRF & As & XRF \\
\hline $\mathrm{Br}$ & $X R F$ & $\mathrm{Rb}$ & $X R F$ \\
\hline$U$ & XRF & Mo & $X R F$ \\
\hline $\mathrm{Ag}$ & XRF & $\mathrm{Cd}$ & $X R F$ \\
\hline
\end{tabular}

Methods

ICP - total fusion, acid dissolution

XRF - direct measurement, X-ray Fluorescence

Either - both methods give same result

\section{MONITORING REQUIREMENTS}

Monitoring for RCRA-regulated hazardous chemicals beneath the 200 Areas

LLBG will be performed only on those samples that have been contaminated by leachates from the units. Detemination of contacted samples will be based on detection of mobile radionuclides attributed to the buried waste. Based on the Hanford Defense Waste-Draft Environmental Impact Statement (USDOE 1986) analysis, it is likely that transport of radionuclides beneath these facilities should only extend for a few meters below the trench bottoms. 
ANALYSIS TO SUPPORT RELEASE AND TRANSPORT CALCULATIONS

Radionuclide analysis will be performed on samples near the trench bottom in boreholes downgradient from the waste sites. Mobile radionuclides known to be associated with wastes buried in each facility will be the focus of the release and transport analysis. Table A.3 lists the radionuclides and techniques that will be used to assess the release and transport of radionuclides beneath the 200 Areas solid waste burial sites.

TABLE A.3. Radionuclides for Release and Transport Analysis

\begin{tabular}{|c|c|}
\hline Radionuclides & Technique \\
\hline Uranium & Laser fluorescence \\
\hline${ }^{137} \mathrm{Cs}$ & $\gamma$ Spectroscopy \\
\hline $241_{A m}$ & $\gamma$ Spect roscopy \\
\hline${ }^{90} \mathrm{Sr}$ & Extraction and liquid scin \\
\hline
\end{tabular}

\section{REFERENCES}

Black, C. A. 1965a. Methods of Soil Analysis. Part 1. Physical and Mineralogical Properties Including Statistics of Measurement and Sampling. American Society of Agronomy, Monograph 9.

Black, C. A. 1965b. Methods of Soil Analysis. Part. 2. Chemical and Microbiological Properties American Society of Agronomy, Monograph 9 .

U.S. Department of Energy (USDOE). 1986. Draft Environmental Impact Statement: Disposal of Hanford Defense Wastes. D0E/EIS-0113, U.S. Department of Energy Washington, D.C. 
$$
\text { . }
$$$$
\text { . }
$$

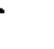


APPENDIX 8

ENGINEERING STUDY 
APPENDIX B

\begin{abstract}
ENGINEERING STUDY
TECHNICAL EVALUATION OF MATERIALS AND METHODS FOR THE CONSTRUCTION OF GROUND-WATER MONITORING WELLS AT RESOURCE CONSERVATION AND RECOVERY ACT REGULATED LOW-LEVEL BURIAL GROUNDS IN THE 200 AREAS, HANFORD SITE.
\end{abstract}

\author{
R. B. Kasper \\ Research and Engineering \\ Rockwell Hanford Operations \\ D. A. Myers \\ Hydrology Section \\ Battelle Pacific Northwest Laboratory
}


TABLE OF COKTERT

EXECUTIVE SUMMARY................................... 4

1.0 INTRODUCTION..................................... 5

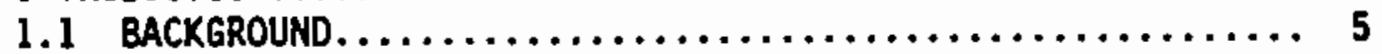

1.2 PURPOSE AND NEED $\ldots \ldots \ldots \ldots \ldots \ldots \ldots \ldots \ldots \ldots \ldots \ldots \ldots, 5$

2.0 RECOMMENDATIONS $\ldots \ldots \ldots \ldots \ldots \ldots \ldots \ldots \ldots \ldots \ldots \ldots \ldots, 7$

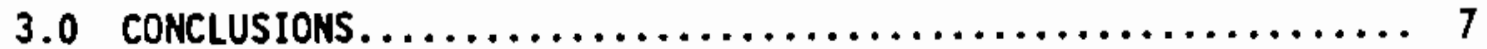

4.0 GENERAL REQUIREMENTS, HANFORD SITE SPECIFIC CONDITIONS AND TECHNICAL ISSUES $\ldots \ldots \ldots \ldots \ldots \ldots \ldots \ldots \ldots, 8$

4.1 GEMERAL REQUIREMENTS $\ldots \ldots \ldots \ldots \ldots \ldots \ldots \ldots \ldots \ldots \ldots, 8$

4.2 HANFORD SITE SPECIFIC CONDITIONS

INFLUENCING WELL DESIGN......................... 9

4.2.1 Geologic Materials..................... 9

4.2.2 Thickness of Saturated and Unsaturated Sediments..................... 11

4.2.3 Geochemistry of the Ground Water.............. 11

4.2.4 Conceptual Design for Monitoring Wells.......... 11

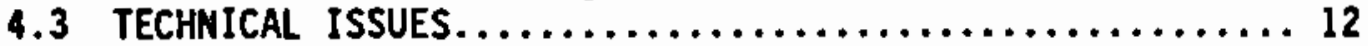

5.0 MATERIAL ALTERNATIVES $\ldots \ldots \ldots \ldots \ldots \ldots \ldots \ldots \ldots \ldots \ldots \ldots \ldots \ldots$

5.1 CRITERIA..................................... 14

5.2 Material alternatives............................ 14

5.2.1 Teflon................................ 15

5.2.2 Stainless Steel Type 316 and $304 \ldots \ldots \ldots \ldots \ldots . .15$

5.2 .3 PVC I................................. 17

5.3 EVALUATION OF MATERIAL ALTERNATIVES............... 18

5.3.1 Technical Evaluation..................... 18

5.3.2 Cost and Schedule Evaluation................ 19

5.4 PREFERRED AlterNATIVE............................ 20

6.0 DRILLING METHOD ALTERNATIVES $\ldots \ldots \ldots \ldots \ldots \ldots \ldots \ldots \ldots \ldots, 2$ I

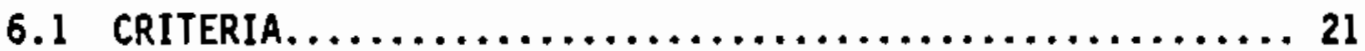

6.2 DRILLING METHOD ALTERNATIVES $\ldots \ldots \ldots \ldots \ldots \ldots \ldots \ldots \ldots \ldots \ldots \ldots$

6.2.1 Cable Tool Method.......................... 22

6.2.2 Rotary Methods........................... 22

6.3 EVALUATION OF DRILLING METHOD ALTERNATIVES........... 23

6.3.1 Technical Evaluation...................... 23

6.3.2 Cost and Schedule Evaluation................ 25

6.4 PREFERRED DRILLING METHOD $\ldots \ldots \ldots \ldots \ldots \ldots \ldots \ldots \ldots, 26$

7.0 WELL COMPLETION ALTERNATIVES $\ldots \ldots \ldots \ldots \ldots \ldots \ldots \ldots \ldots \ldots \ldots, 28$

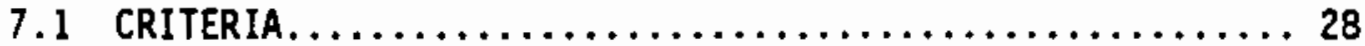

7.2 WELL COMPLETION ALTERNATIVES $\ldots \ldots \ldots \ldots \ldots \ldots \ldots \ldots \ldots, 28$

7.3 EVALUATION OF WELL COMPLETION ALTERNATIVES........... 29

7.4 PREFERRED ALTERNATIVE........................... 29 


\section{TABLE OF CONTERTS (Continued)}

8.0 MONITORING WELL DIAMETER ALTERNATIVES $\ldots \ldots \ldots \ldots \ldots \ldots \ldots \ldots, \ldots$

8.1 CRITERIA.................................. 30

8.2 SAMPLING/PURGING METHODS AND EqUI PMENT ALTERNATIVES........................ 30

8.3 WATER LEVEL MEASUREMENT ALTERNATIVES $\ldots \ldots \ldots \ldots \ldots \ldots, 31$

8.4 EVALUATION OF ALTERNATIVES $\ldots \ldots \ldots \ldots \ldots \ldots \ldots \ldots \ldots, 32$

8.4.1 Technical Evaluation..................... 32

8.4.2 Cost and Schedule Evaluation................ 34

8.5 PreferRed alternative.......................... 35

9.0 BOREHOLE DIAMETER AND CLEARANCE ALTERNATIVES $\ldots \ldots \ldots \ldots \ldots \ldots, 37$

9.1 CRITERIA $\ldots \ldots \ldots \ldots \ldots \ldots \ldots \ldots \ldots \ldots \ldots \ldots \ldots \ldots \ldots \ldots \ldots \ldots, 37$

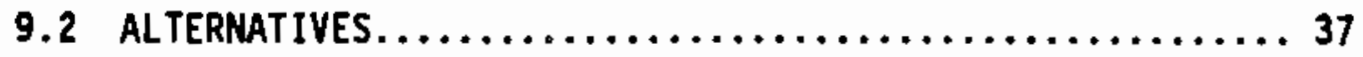

9.2.I Pouring materials....................... 37

9.2.2 Tremie pipe............................. 38

9.3 EVALUATION OF ALTERMATIVES $\ldots \ldots \ldots \ldots \ldots \ldots \ldots \ldots \ldots, \ldots \ldots$

9.3.I Technical Evaluation...................... 38

9.3.2 Cost and Schedule Evaluation................. 39

9.4 PREFERRED alternative......................... 40

10.0 REFERENCES.................................... 41

\section{TABLES}

Table 1 - Particle Size Designation........................ 10

Table 2 - Dimensions and Strength Data for Casing.............. 16

Table 3 - Comparison of Cost of Casing for Various Materials.......................... 20

Table 4 - Cost and Schedule Somparison for Drilling Standard Shallow Well Design Using Cable Tool and Air Rotary Methods................. 26

Table 5 - Cost for Type 304 Stainless Steel Flush Joint Casing in 10-Foot Lengths................... 34

Table 6 - Compartson of Cost for Clearance Alternatives Standard Shallow Well Design.................... 40 


\section{EXECLTIVE SUHARY}

The U. S. Department of Energy-Richland Operations Office (DOE-RL) has agreed with the U. S. Environmental Protection Agency (EPA) and the Washington State Department of Ecology (WDOE) to install ground-water monitoring systems at those Low-Level Burial Grounds (LLBG) that have received radioactive mixed waste after November 19, 1980, according to Resource Conservation and Recovery Act (RCRA) and Washington Administrative Code (HAC) regulations. Regulated LLBG include (218-)W-3A, W-3AE, $W-4 C$ and $W-5$ in 200 West Area, and E-10 and E-12B in 200 East Area.

Ground-water monitoring systems are required for burial grounds under interim status ( 40 CFR 265, Subpart F). The DOE-RL, EPA, and WOOE have agreed to the installation of not more than 35 monitoring wells at the regulated LLBG by the end of November, 1987 as part of the compliance effort with RCRA and WAC regulations. The initial installation of ground-water monitoring systems are being conducted under fiscal year 87 General Plant Projects B-677 and B-678 for the 200 West Area and the 200 East Area LLBG, respectively. The objectives of these projects are to install independent monitoring systers for the regulated LLBG and characterize the hydrogeologic environment in order to evaluate the adequacy of the independent systems to meet the requirements of a RCRA compliance system. On the basis of the results obtained, additional will be proposed, as required.

This engineering study evaluates certain technical issues related to monitoring well design and construction methods. The location of individual wells that compose the monitoring system at each LLBG is documented in the compliance plan submitted to EPA and WDOE. The requirement that the monitoring well installation be completed by November 30, 1987 resulted in a conservative approach being taken for the selection of materials and methods of construction. This approach favors the use of proven materials and techniques. Experience gained form these projects will be used for further refinement of the well design and construction methods.

The preferred alternative, at this time, for well construction is to use type 304 stainless steel casing and screen. Type 304 stainiess stee has acceptabie chenical stability and structural strength to provide adequate service for the design life of 50-plus years for the monitoring well. The monitoring well will be constructed using 4-in. inside diameter casing and screen. Cable tool drilling equipment will be used to drill an oversized borehole that will be supported by temporary casing of at least $8-i n$. inside diameter. The actual monitoring well will be constructed inside the borehole and, as the temporary casing is removed, the required seal material will be added. The use of air rotary equipment will be considered an alternative for a limited number of wells. Total estimated cost for both projects to include 35 wells of not more than 11,000 total feet of drilling is $\$ 1,980,000$. 


\subsection{INTRODUCTION}

\subsection{BACKGROUND}

The U. S. Department of Energy - Richland Operations Office (DOE-RL) has agreed with the U. S. Environmental Protection Agency (EPA) and the Washington State Department of Ecology (WDOE) to install ground-water monitoring systems at those Low-Level Burial Grounds (LLBG) that have received radioactive mixed waste (RMW) after November 19, 1980, according to Resource Conservation and Recovery ACt (RCRA) and Washington Administrative Code (WAC) regulations. Regulated LLBG in 200 West Area include (218-)W-3A, W-3AE, W-4C and W-5. Regulated LLBG in the 200 East Area include (218-)E-10 and E-12B. A Part B Permit Application for the regulated LLBG has been submitted by DOE-RL. Until the permit is obtained, these LL8G will be operated under interim status according to Subpart F, 40 CFR 265, which spectfies the requirements for ground-water monitoring systems of sites regulated under RCRA.

A plan for a ground-water monitoring system in compliance with RCRA is developed through negotiations with EPA, and WDOE. Negotiations between DOE-RL, EPA and WDOE resulted in agreement that a phased approach to obtaining compliance of the regulated LLBG was acceptable. A consent agreement and compliance order (WDOE 1986) commits DOE-RL to drill "...not more than 35 wells, nor more than 11,000 total feet of well...no later than November 30, 1987."

The installation of ground-water monitoring systems in accordance with the consent agreement and compliance order is being conducted under fiscal year (FY) 1987 General Plant Project (GPP) B-677 for 200 West Area LL8G and B-678 for 200 East Area LLBG. Nineteen wells are planned for the regulated LLBG in 200 West Area in GPP 8-677. The estimated cost for GPP B-677 is $\$ 1,090,000$. Sixteen wells are planned for the regulated LLBG in 200 East Area in GPP B-678. The estimated cost for GPP B-678 is $\$ 890,000$. Total estimated cost for both GPPs is $\$ 1,980,000$.

\subsection{PURPOSE AND NEED}

General P1ant Projects B-677 and B-678 have two main objectives: 1) insta7l an independent monitoring system for the regulated LLBG as specified in the Consent Agreement and Compliance Order and 2) characterize the hydrogeologic environment in order to evaluate the adequacy of the independent system to meet the requirements of a system in compliance with RCRA. On the basis of the results obtained, additional work will be proposed, as required. Details of the monitoring system being implemented under GPPS B-677 and B-678 will be documented in a compliance plan prepared by DOE-RL for EPA and WDOE. The compliance plan will contain information on monitoring well location, well construction materials and design, drilling methods, and characterization work. 
This engineering study (ES) supports the compliance plan by providing evaluation of alternate methods and materials for design and construction of individual monitoring wells, and recomendations for a preferred design that is suitable for Hanford site specific conditions. In order to meet the requirement for completion of the monitoring wells by November 30, 1987, a conservative approach was taken for the selection of materials and methods of construction. This approach favors the use of proven techniques and materials. Information and experience gained specifically from the design and installation of monitoring wells at RCRA regulated sites in the $100 \mathrm{H}$ Area, the 300 Area and the Non-Radioactive Dangerous Waste Landfill along with open literature information was used in this evaluation of materials and methods. Experience gained from these projects and continuing evaluation of alternate materials and methods will be used for further refinement of the well design and construction techniques. 


\subsection{RECOMHENATIONS}

It is reconmended that, under GPPS B-677 and B-678, ground-water wells for RCRA monitoring at regulated LLBG in the 200 Areas of the Hanford Site be constructed using 4-in. inside diameter casing and screen manufactured of type 304 stainless steel. The casing and screen must be joined using threaded couplings and not welded. The actual monitoring well will be constructed inside an oversized borehole which will be drilled using cable tool equipment. Temporary casing with a minimum inside diameter of 8-in. will be used during drilling to support the borehole and prevent collapse. As the temporary casing is removed, the required sealing material will be added between the monitoring well and the wall of the borehole to ensure an acceptable seal.

The use of schedule 80 , flush threaded, casing and screen manufactured of polyvinylchloride (PVC) is considered a potential alternative to type 304 stainless steel. PVC has comparable chemical resistance under anticipated Hanford Site conditions, does not have potential for galvanic corrosion and is less expensive. However, PVC is structurally weaker than stainless steel and performance is affected by temperature. The use of PVC would require special care and handling during construction. There are also unresolved technical issues concerning the long term performance of PVC monitoring wells constructed at the depths required.

The use of air rotary drilling equipment is considered a potential alternative to use of cable tool equipment. Air rotary drilling offers significant advantages in rate of drilling over cable tool equipment with potential cost savings. Techniques for containment of radioactive contaminants being developed at the DOE Oak Ridge Site can be applied here. However, past experience has indicated that rotary methods may have difficulty in penetrating the coarse, unconsolidated sediments which are present in the unsaturated zone in the vicinity of the 200 Areas. The limited number of wells drilled by the rotary method in the past at the Hanford Site is not sufficient to evaluate the capabilities of new rotary equipment and methods.

\subsection{CONCLUSIONS}

Monitoring wells are required at regulated $L L B G$ in the 200 Areas to meet the RCRA requirements for ground-water monitoring of regulated facilities. The recommended monitoring well design and construction methods meet the general requirements established in Subpart $F$ of 40 CFR 265, satisfy technical guidance criteria recommended by EPA, and use acceptable selection of methods and material suitable for site specific conditions.

Alternatives are avajlable for the recommended material and the drilling method that offer potential cost and schedule savings. These alternatives need to be further evaluated with regard to meeting the regulatory requirements and suitability for site specific conditions. Testing of the rotary drilling method and use of PVC casing and screen at the Hanford Site should be considered for selected monitoring wells not part of the RCRA regulated sites. 
RE-ES-037 Rev. 0

\subsection{GEMERAL REQUIREMEMTS, HANFORD SITE SPECIFIC CONDITIONS, AN TECHAICAL ISSUES}

\subsection{GENERAL REQUIREMENTS}

The requirements for interin status ground-water monitoring at hazardous waste sites are identified in Subpart F, 40 CFR 265 . The requirements for a ground-water monitoring system are specified in 40 CFR 265.91(a):

"(1) Monitoring wells... installed hydraulically upgradient.... Their number, location, and depths must be sufficient to yield ground water samples that are:

(i) Representative of background ground-water quality in the uppermost aquifer near the facility; and

(ii) Not affected by the facility; and

(2) Monitoring wells... installed hydraulically down gradient... at the linit of the waste management area. Their number, location, and depths must ensure that they imediately detect any statistically significant amounts of hazardous waste or hazardous waste constituents that migrate from the waste management area to the uppermost aquifer."

A proposed monitoring system designed to meet site-specific conditions is described in the compliance plan prepared by DOE-RL for submission to EPA and HOOE. The compliance plan contains details on monitoring well locations and numbers, well construction design and materials, drilling methods, and characterization work. This ES supports and provides a basis for the compliance plan. The scope of the ES is to provide an evaluation of alternate methods and materials for design and construction of individual monitoring wells and recomendations supporting the preferred design that is suitable for Hanford Site specific conditions.

The general requirements for the construction of a monitoring well contained. in 40 CFR $265.91(\mathrm{c})$ specify:

(1) "Al1 monitoring wells must be cased in a manner that maintains the integrity. of the monitoring well bore."

(2) "This casing must be screened or perforated, and packed with gravel or sand where necessary, to enable sample collection at depths where appropriate aquifer flow zones exist."

(3) "The annular space (i.e. the space between the bore hole and well casing) above the sampling depth must be sealed with a suitable material (e.g., cement grout or bentonite slurry) to prevent contamination of samples and the ground water." 
These requirements provide only general specifications concerning the construction of monitoring wells. Design of a ground-water monitoring system requires the determination of site-specific conditions and the evaluation and consideration of methods, procedures, and materials that meet the requirements. Various different methods and materials are available that may appear suitable but are inadequate for specific conditions encountered at Hanford. Evaluation of methods and materials for construction of monitoring wells must consider conditions specifically at the 200 Areas of the Hanford Site. For a general technical explanation of well drilling and completion methods, refer to Driscoll (1986) and EPA (1985, 1986).

\subsection{HANFORD SITE SPECIFIC CONDITIONS INFLUENCING WELL DESIGN}

The design and construction requirements for monitoring wells are dependent upon site specific conditions. Specific conditions at the 200 Areas LLBG that influence the selection of methods and materials for construction of monitoring wells include:

- Type of geologic materials that will be drilled through

- Thickness of saturated and unsaturated sediment (contro) the depth wells are dritled)

- Geochemical conditions of the ground water

Each of these topics and the potential impact on method and materials selection for construction of monitoring wells will be discussed in the following sections.

\subsubsection{Geologic Materials}

The geology and stratigraphy in the vicinity of the 200 Areas are summarized by Tallman et al. (1979). In drilling wells at the regulated LLBG two major sedimentary formations are encountered: the Ringold formation and the (informal) Hanford formation. Both the Hanford and Ringold formations contain gravel units with particle sizes that range up to large cobbles and include occasional boulders. Orilling through units with such coarse particles can be difficult, especially in the Hanford formation where the material is unconsolidated. The drilling tools may not penetrate large particles but instead push them to the side which can result in deflection of the drilling string and the resulting borehole. In addition, drilling in the unconsolidated Hanford formation requires the use of temporary casing to support the borehole.

The Ringold formation is a fluvial deposit laid down by the ancestral Columbia River. Four units are identified: upper, middle, lower, and basal. In the vicinity of the 200 Areas, the unconfined aquifer generally occurs in the middle Ringold unit, and most monitoring wells will be drilled and completed in this unit. The middle Ringold unit consists of well-rounded pebbles and cobbles (Table 1). The interstitial spaces are filled by a coarse-to-fine sand and silt 
matrix. Variable amounts of cementation occur with the amount generally increasing with depth. In the vicinity of the 200 East Area, the lower Ringold unit is missing and the middle Ringold is not distinguished from the texturally similar basal Ringold.

TABLE 1

PARTICLE SIZE DESIGNATION

(modified after Wentworth 1922)

PARTICLE

DESIGNATION
PARTICLE

OIAMETER

(mm)

$>256$

$256-128$

LARGE

$128-64$

PEBBLE:

VERY COARSE $64-32$

COARSE $32-16$

MEDIUM $16-8$

FINE $8-4$

VERY FINE $4-2$

$2 \cdot 1$

$1-1 / 2$

$1 / 2-1 / 4$

$1 / 4-1 / 8$

$1 / 8-1 / 16$

$<1 / 16$

SILT AND CLAY

The Hanford formation overlays the Ringold formation and comprises most of the unsaturated zone. The Hanford formation is a glaciofluvial deposit laid down by multiple catastrophic Pleistocene floods. The 200 Areas are located on a giant bar formed by a side current of the flood waters passing between Gable Butte and Umtanum Ridge. The bar is composed predominantly of sand-sized particles, which supports the hypothesis that the sediments were deposited away from the main current channel that was presumably located north of the Gable Butte-Gable Ridge structure. However, sediments coarsen upward to gravel facies, which contain pebble-, cobble- and some boulder-sized particles. The increasing particle size suggests either higher water. volumes or a shift of the main current channel. The Hanford formation is generally unconsolidated. The unconfined aquifer includes the lower portion of the Hanford formation in some 1 imited locations. 


\subsubsection{Thickness of Saturated and Unsaturated Sediments}

The depth to ground water in the vicinity of the 200 Areas can be evaluated from a series of semiannual water-table maps published for the Hanford Site. The water table beneath the 200 Areas is influenced by changing waste water disposal operations, but the most recent water-table map for June 1986 (Schatz and Jensen 1986) shows that the water table decreases from approximately 470 to $410 \mathrm{ft}$ above mean sea level (ms 1) from west to east across the two areas. Ground surface ranges from approximately 600 to $720 \mathrm{ft}$ above $\mathrm{msl}$ in the 200 Areas. In the vicinity of the regulated LLBG, depth to ground water will range from approximately $200 \mathrm{ft}$ to around $300 \mathrm{ft}$.

Total unconfined aquifer thickness is evaiuated from the water-table map and the geologic cross sections in Tallman et al. (1979). In 200 East Area, the confining unit is considered to be the Columbia River basalt surface. The surface of the basalt generally dips to the south toward the Cold Creek syncline. In the vicinity of the 200 East Area regulated LLBG, the basalt surface occurs between 350 and $400 \mathrm{ft}$ above ms 1 . The total unconfined aquifer thickness is generally less than $100 \mathrm{ft}$, ranging from approximately 10 to $60 \mathrm{ft}$.

In 200 West Area, the confining unit is considered to be the lower Ringold unit (Graham, 1981). In the vicinity of the 200 West Area regulated LLBG, the upper surface of the lower Ringold unit occurs between 200 and $300 \mathrm{ft}$ above ms 1 and the total aquifer thickness ranges between less than $200 \mathrm{ft}$ to almost $300 \mathrm{ft}$.

\subsubsection{Geochemistry of the Ground Water}

Ground-water chemistry in the Separations Area was sumarized by Graham (1981). Overall, the unconfined ground water can be classified as a calcjum-bicarbonate type. In the northern part of the Separations Area, calcium-sulfate waters occur. To the southeast of the 200 East Area, there is a gradual change to a sodium-bicarbonate type. This change in chemical character is probably due to mixing with aqueous waste waters containing sodium nitrate discharged to the ground in and near 200 East Area. Although contaminant piumes from several waste disposal facilities contribute radioactive components and nitrate to the ground water, overall the ground water appears to be a dilute, inorganic, neutral-to-slightly basic (pH between 7.0 and 8.5 ) solution.

\subsubsection{Conceptual Desion for Monitoring Hells}

Characterization of the hydrogeologic environment requires that some wells be drilled to the bottom of the unconfined aquifer in order to determine such data as the geology of the site, and to evaluate the vertical hydrologic gradient. The requirement for an independent monitoring system for the regulated LLBG can be satisfied at this time by monitoring wells completed in the top of the unconfined aquifer, where any contaminant leaching from the LLBG would first contact the ground water.

$$
8.11
$$


To meet both objectives, two well designs must be considered. The majority of wells will be completed at the top of the unconfined aquifer and are identified as shallow wells. A smaller number of vells, in particular wells in the 200 West Area, will be completed at the bottom of the unconfined aquifer and are identified as deep wells. A standard shallow-well design and a standard deep-well design will be used as the basis for evaluating the performance of methods or materials and estimating the cost. The following are assumptions used in both designs:

The standard shallow-well design assumes:

- The water table occurs at a depth of $250 \mathrm{ft}$ below ground surface

- The borehole will be drilled $20 \mathrm{ft}$ below the water table

- The well will be constructed with $15 \mathrm{ft}$ of screen below the water table and 5 feet of screen above the water table.

The standard deep-we11 design assumes:

- The water table occurs at a depth of $250 \mathrm{ft}$ below ground surface

- The bottom of the unconfined aquifer occurs at a depth of $450 \mathrm{ft}$

- The deep well will be constructed with $10 \mathrm{ft}$ of screen at the bottom of the aquifer.

\subsection{TECHNICAL ISSUES}

The scope of this ES is to provide an evaluation of alternative methods and materials for construction of individual monitoring wells and recomendations for a preferred design suitable for site specific conditions. Because of the limited time available for completion of the project (all wells must be drilled by November 30,1987 ) and the long design 1 ife required, a conservative approach is preferred for the selection of materials and methods of construction. This approach favors a simple design, that requires minimum maintenance and uses proven techniques and materials. Specific major technical issues and criteria have been identified. Those methods or materials that are cleariy inadequate will not be considered in detail. Methods and materials that may be appropriate will be evaluated in detail on both technical merits and, if appropriate, on a cost and schedule basis. Cost and schedule requirements will be considered for comparison and, where differences in technical merit are not significant, may provide additional justification in the selection of alternate methods or materiais. 
Five major technical issues will be evaluated in this ES:

- Materials for each monitoring we1l design

- Dril1ing methods

- Monitoring well compietion techniques (e.g., methods for sealing the annular space)

- Monitoring well diameter

- Borehole size

For each issue, the specific criteria to be met will be identified. A discussion of all alternatives will be given and alternatives clearly unsuitable will be rejected. An evaluation will be made comparing technical merit and, if appropriate, cost and schedule requirements of the remaining alternatives. The preferred alternative will be identified. 


\subsection{MATERIAL ALTERHATIVES}

\subsection{CRITERIA}

The casing and screen materials for both the shallow and the deep monitoring wells will be evaluated on the basis of the following requirements:

1. The materials must not chemically react in the anticipated environment.

2. The materials must have the structural strength required for installation.

3. The materials must last for the operational period of the LLBG and for the 30-yr postclosure period.

\subsection{MATERIAL ALTERNATIVES}

A variety of rigid materials have been used for construction of ground-water monitoring wells. Barcelona et al. (1983) evaluated the chemical compatibility of various rigid materials in 4 different categories of ground-water conditions. Rigid materials included Teflon, stainless steel types 304 and 316, galvanized steel, carbon steel, low-carbon steel and polyvinylchlortde (PVC). Chemical environments included: buffered weak acid, weak acid, mineral acid/high solids, and aqueous/organic mixtures. Teflon rated highest overall followed by stainless steel type 316, stainless steel type 304, PVC, low- carbon steel, galvanized steel, and carbon steel. The overall rating however reflects the materials compatibility with four completely different chemical environments. For specific chemical environnents, several materials may do equally well. For example, PVC performed as well as Teflon under buffered weak acid and mineral acid/high solids conditions. Stainless steel 316 performed as well as Teflon except under mineral acid/high solids conditions. Barcelona et al. (1983) recommended, in decreasing order of preference, Teflon, stainless steel, and PVC. Based on the results of Barcelona et a1. (1983), the EPA (EPA 1985) recommended the use of Teflon, stainless steel 316 , or other proven chenically and physically stable materials for those portions of the monitoring well below the water table.

The selection of materials for monitoring well construction must be based on the actual conditions to be encountered at the Hanford Site. The ground-water environment (see section 4.2.3) is far less aggressive than any of the chemical conditions evaluated by Barcelona et al.(1983). In addition, construction of monitoring wells to depths from 200 to $300 \mathrm{ft}$, or greater, requires materials with adequate strength for both installation and long-term performance.

In the evaluation of materials, consideration will be given to stainless stee? type 304 and PVC, in addition to Teflon and stainless steel type 316. Carbon steels and galvanized steel are considered unacceptable due to proven long-term corrosion problems encountered in existing ground-water and vadose-zone monitoring wells at the Hanford Site.

$$
\text { B.1. }
$$




\subsubsection{Ieflon}

From purely chemical consideration, Teflon is nearly an ideal well construction material. Teflon has excellent chenical stability under almost all chemical environments, has poor sorption properties, and has a very low potential for leaching components to the ground water.

The disadvantages of Teflon relate to its structural stability. Under stress, Teflon will deform. If a sufficient length of casing is being lowered down the bore hole, the threaded sections can deform and release. A Teflon screen can also deform because of the weight of casing above and can reduce or close off the screen openings. Although installation techniques have been developed to mitigate this problem, it is not possible to determine the actual screen size upon completion, or to prevent long-term deformation. Use of Tefion for casing or screen below a depth of approximately $100 \mathrm{ft}$ is not recommended (8arcelona et al, 1983).

\subsubsection{Stainiess Steel Troes 316 and 304}

The principal difference between the two types is the inclusion of 2-3\% molybdenum in stainless steel type 316. The molybdenum gives the stainless steel type 316 improved resistance to sulfur-containing species as well as sulfuric acid solutions. As a result, stainless steel type 316 is given a sightly better rating than stainless steel type 304 by Barcelona et a1. (1983). For many monitoring applications, both steels can function nearly as well as Tefion. Buffered weak acid solutions can attack type 304 stainless steel. This problem has been encountered at the U.S.DOE Savannah River Plant where ground water with a pH of 4.5 to 5 extensively attacks stainless steel wells. However, both type 304 and type 316 stainless steel should exhibit good chemical resistance at the $\mathrm{pH}(7.5$ to 8.0$)$, low temperature and salinities experienced at the Manford Site. Although the stainless steels will be resistant to chemical attack, galvanic corrosion is a potential problem with all metallic materials if two dissimilar metals (such as stainless steel and another metal or welding material) are in contact in an electrolytic solution. Galvanic corrosion is a problem in tank farms at the Hanford Site where stainless steel pipe is welded together, and galvanic (cathodic) protection is required.

Table 2 provides dimensions and strength data for casing manufactured of type 304 stainless steel. Data for nominal 4-in., 5-in., and 6-in. casing is listed. Casing made from either type of stainjess steel would have excellent structural strength and can stand up to the conditions encountered at depths of hundreds of $\mathrm{ft}$. Casing and screen manufactured from stainiess steel type 304 is readily available in a variety of diameters, indicating its common usage. Casing and screens manufactured from stainless steel type 316 will require a special order.

The main disadvantage of the stainless steels is the increased cost compared to other types of steel and synthetic materials other than Teflon. Galvanic corrosion is a potential disadvantage but proper well design (using threaded 
Table 2. Dimensions and Strength Data for Casing (Fram Johnson Groundwater fonitoring Products Catalog)

\begin{tabular}{|c|c|c|c|c|c|c|c|c|}
\hline \multirow[b]{2}{*}{ Material } & \multirow[b]{2}{*}{ Nominal Słze } & \multirow[b]{2}{*}{$\begin{array}{l}0.0 . \\
\text { (in) }\end{array}$} & \multirow[b]{2}{*}{$\begin{array}{l}\text { I.D. } \\
\text { (in) }\end{array}$} & \multirow[b]{2}{*}{$\begin{array}{l}W T \\
(1 \mathrm{~b} / \mathrm{ft})\end{array}$} & \multicolumn{4}{|c|}{ Strength } \\
\hline & & & & & $\begin{array}{l}\text { Collapse } \\
\text { (psi) }\end{array}$ & $\begin{array}{l}\text { Tensile } \\
\text { (lb) }\end{array}$ & $\begin{array}{c}\text { Colum } \\
\text { (lb) }\end{array}$ & $\begin{array}{l}\text { Joint } \\
\text { Jensile } \\
\text { (lb) }\end{array}$ \\
\hline$P N C$ & 4-in. sch. 80 & 4.500 & 3.826 & 2.6 & 494 & 30,850 & 1,375 & 5,050 \\
\hline $\mathrm{PVC}$ & 5-in. sch. 80 & 5.563 & 4.813 & 3.9 & 324 & 42,780 & 2,940 & 6,050 \\
\hline PYC & 6 -in. sch. 80 & 6.625 & 5.761 & 5.4 & 292 & 58,630 & 5,760 & 4,000 \\
\hline S.S. ${ }^{1}$ & 4 -in. sch. $5 / 40^{2}$ & 4.500 & 4.026 & 4.0 & 315 & 92,000 & 26,800 & 81,750 \\
\hline S.S. 1 & 5-in. sch. $5 / 40^{2}$ & 5.563 & 5.047 & 6.5 & 350 & 148,800 & 66,660 & 91,500 \\
\hline S.S. ${ }^{1}$ & 6 -in. sch. $5 / 40^{2}$ & 6.625 & 6.407 & 7.6 & 129 & 178,400 & 113,660 & 94,500 \\
\hline
\end{tabular}

1 Type 304 Stainless Steel

2 Casing is Schedule 5, Threaded Fittings are Schedule 40 
coupling, avoiding welding, using only the same type of steel) should mitigate this problen. Galvanic corrosion could be el iminated by the addition of galvanic (cathodic) protection.

\subsubsection{PVC}

The advantages of PVC material include good availability and relative low cost. PVC has good chemical resistance although it can be attacked by organic solvents such as ketones, esters, and chlorinated and aromatic hydrocarbons. However, organic solvents are not likely to be encountered in ground-water monitoring applications in concentrations high enough to damage PVC. PVC has been shown to have the potential to both leach and sorb organic materials from the polymer matrix (Barcelona et a1. 1983). This is not considered a problem because the standard purging requirements of a well prior to sampling limits contact time of fresh formation water with the monitoring well casing and screen.

Table 2 provides dimensions and strengths for schedule 80 casing manufactured of PVC. Schedule 40 PVC casing is not considered suitable for use at the depths required and thicker walled schedule 80 casing is evaluated. Data for nominal 4-in., 5-in., and 6-in. internal diameter material is 1 isted.

Casing manufactured from PVC is significantly weaker than comparable sized items manufactured from type 304 stainless steel. (In fact, PVC screen of a continuous wire wrap design does not have adequate column strength to support the weight of the rest of the casing at the depths required.) The difference in strength of PVC casing compared to stainless steel is particularly obvious for column and joint tensile strength. The joint tensile strength for the PVC casing is only 6,000 $\mathrm{lb}$ for 4-in. and 5-in. casing compared to greater than 80,000 $\mathrm{ib}$ for stainless steel. While the listed strengths are sufficient to support the monitoring well during installation, there is not as much margin if problems develop during, installation and the casing has to be adjusted in the borehole.

PVC is also a more difficult material to handle for installation than stainless steel and requires special care. The performance of PVC is temperature dependent. In cold weather the PVC becomes brittle; in hot weather the material can warp. If not properly protected during storage PVC can also suffer degradation from exposure to sunlight. Higher temperatures also weakens PVC. Care must be taken when portland cement based grout is used to provide a seal. The cement's heat of hydration softens the PVC, resuiting in collapse of the monitoring well. Driscoll (1986) indicates that typically a cement grout should not be more than 2-in. thick to prevent deformation and collapse of PVC casing. Cement based grouts should not be used with PVC casing at all at depths below 300 feet.

The structural strength and flexibility of PVC is also a potentia? disadvantage for long-term monitoring well applications. Oriscoll (1986) indicates that while plastic casing can be set to depths of 1000 feet, the selection of any plastic materials for wells deeper than 300 feet should be made with caution. As a result, while PVC materials may be suitable for the shallow 
well design, it is probably not acceptable for the deep well design. Oriscoll (1986) points out that, because of the viscoelastic nature of plastic materials, the long-term strength of plastic materials is significantly less than indicated by short-term tests. The long-term compressive strength of PVC casing may be only one-fifth the value indicated in Table 2. Long-term deformation after the well has been completed at the depths required in the vicinity of the 200 Areas may reduce clearance sufficiently to prevent used of certain purging or sampling equi pment.

One problem with schedule 80 PVC casing results from the current requirement for adequate clearance for installation of a submersible pump (Section 8.0). Examination of Table 2 indicates that schedule $80,4-i n$. PVC casing has an internal dianeter of $3.826 \mathrm{in}$.; less than $1 / 16-i n$. of clearance is available for. installation of a submersible pump with an outside diameter of 3.750-in. This may be insufficient clearance and any deformation of the casing would prevent use of a submersible pump. PVC casing of 5-in. or 6-in. size would provide adequate. clearance. However, use of larger diameter PVC casing would decrease the cost advantage of PVC monitoring wells. In addition to the cost of the monitoring well material, additional cost would be incurred for both drilling expense and temporary materials. A 5-in. or 6- in. well casing would require a mintmum 10-in. temporary casing $d t$ ameter to provide adequate clearance for installation of sealing material (Section 9.0).

\subsection{EVALUATION OF MATERIAL ALTERNATIVES}

\subsubsection{Technical Evaluation}

Criteria 1: The materials must not chemically react in the anticipated environment.

For the nonaggressive chemical environment anticipated in the ground water at the Hanford Site, all four materials will probably perform equally well. Teflon, stainless steel types 316 or 304 , and PVC will not react with the ground water and should not effect the quality of ground-water samples. Galvanic corrosion of stainless steel material can be mitigated by the use of threaded casing and screen. Cathodic protection could be added, if necessary, to eliminate galvanic corrosion.

Criteria 2: The materials must have the structural strength required for installation.

The use of Tefion below a depth of $100 \mathrm{ft}$. is unacceptable. Structural deformation appears to be a significant problem. The use of schedule 40 PVC appears to be unacceptable for the same reasons as given for Teflon. Schedule 80 PVC has adequate strength for well installation at depths to $300 \mathrm{ft}$, if no problems are encountered, and should be acceptable for construction of the shallow monitoring well design. Schedule 80 PVC material may not be adequate for the deep well design due to long-term deformation. PVC becomes brittle in cold weather and assembly of the monitoring well during winter months may be 


$$
\text { RE-ES-037: Rev. } 0
$$

difficult. During the summer months PYC material would have to be protected from the heat and direct exposure to the sun for extended periods of time. Stainless steel types 316 and 304 have the structural strength required for construction of both the deep and shallow monitoring well designs.

Criteria 3: The materials must last for the operational period of the LLBG and for the 30-year postclosure period.

This criteria provides an evaluation over the long-term of the material performance addressed in Criteria 1 and 2 . Will the material degrade due to chemical attack over a long period of time, or will the material deform due to physical processes? Teflon will show no degradation due to chemical attack. However, structural deformation of Teflon, both in the short-term and the long-term, results in Teflon being considered unacceptable for this application. Either type 304 or type 316 stainless steel should show no degradation due to chemical attack. The potential exists for galvanic corrosion, but this problem, if present, can be mitigated or el iminated by proper well design or by adding cathodic protection if necessary. PVC will show no degradation due to chemical attack. Deformation of PVC may be a problem in the long-term, in particular for smaller diameter casing where there is 1 imited clearance for sampling and purging equipment. However, insufficient information is available to adequately evaluate the extent of the problem.

\subsubsection{Cost and Schedule Evaluation}

The approximate list prices for 2-in. and 4-in. internal diameter casings made of Tefion, PVC, and stainless steel 316 or 304 are shown in table 3. Cost comparisons in dollars per foot are based on casing with flush-threaded joints in 10-ft lengths.

Teflon is the most expensive material. The $250 \mathrm{ft}$ of 2 -in. diameter casing required for the standard shallow well design would cost $\$ 7,500$ at list price. The 4-in. diameter casing would cost $\$ 20,000$. The use of PVC for the shallow monitoring well design would be the least expensive, costing only $\$ 625$ for the 2in. casing and $\$ 1,250$ for the 4-in. casing. The stainless steels would cost between $\$ 2,000$ and $\$ 3,000$ for the 2 -in. casing, and between $\$ 4,500$ and $\$ 6,250$ for the 4 -in. casing.

The availability of materials will affect the lead time required in placing orders and initiating drilling. The PVC is readily available. Stainless steel type 304 is commonly used in the construction of monitoring wells and is reasonably available although the quantities required to complete all wells in B-677 and B-678 may result in some delay in acquiring all the materials. Tefton casing manufactured for monitoring well construction is available, although, like stainiess steel type 304, the quantities required may result in some delay in acquiring them. Casing manufactured of stainless steel type 316 is not commoniy available and requires approximately 12 weeks lead time for the necessary quantities.

\subsection{9}


TABLE 3

COMPARISON OF COST OF CASING

FOR VARIOUS MATERIALS

$\begin{array}{lcl}\text { MATERIAL } & \begin{array}{c}\operatorname{COST}^{A} \\ (2-\text { in. i.d. })\end{array} & \begin{array}{c}\operatorname{COST}^{A} \\ (4-i n . i . d .)\end{array} \\ \text { Teflon } & \$ 30.00 & \$ 80.00(\$ 100.00) \\ 316 \text { stainless steel } & \$ 12.00 & \$ 25.00 \\ 304 \text { stainless steel } & \$ 8.70 & \$ 18.00 \\ \text { PVC } & \$ 2.50 & \$ 5.00(\$ 8.00)\end{array}$

A Cost is dollars per 1 inear foot of casing based on 10-ft lengths with flush threaded Joint. Schedule 40 for Teflon and PVC (Schedule 80 costs for 4-in. teflon and PVC casing shown in parentheses); Schedule 5/40 for stainless stee] types 316 and 304.

\subsection{PREFERRED ALTERNATIVE}

The selection of material for the manufacture of the casing and the screen is the most important issue in the design of the monitoring well. Based on the technical evaluation, the preferred material, at the present time, is stainless steel type 304. For anticipated conditions, stainless steel type 304 has the required chemical stability and structural strength to meet the specified criteria. Stainless steel type 316 would not be expected to perform better under the anticipated conditions and would cost approximately $50 \%$ more. The two disadvantages of stainless steel are the potential for galvanic corrosion and cost compared to plastic materials.

The use of schedule 80 , flush threaded casing manufactured of polyvinylchloride (PVC) is considered a potential alternative to stainless steel. PVC has comparable chemical resistance under Hanford Site conditions, does not have potential for galvanic corrosion and is less expensive than stainless steel. However, until pumps with outside diameters less than 3-in., and with acceptable performance have been identified, 5-in. or 6-in. PVC casing would be required to provide adequate clearance for installation of a submersible pump. The larger diameter would decrease the cost advantage for PVC construction. In addition, PVC is not as strong as stainiess steel. PVC materials would require special handling during installation. There are also unresolved technical issues over installation and long-term performance for application in monitoring well construction at the depths required. 
RE-ES-037 Rev. 0

\subsection{DRILLING METHOD ALTERHATIVES}

\subsection{CRITERIA}

The drilling methods will be evaluated on the basis of the following requirements:

1. Orill borehole to depths between 200 to $600 \mathrm{ft}$.

2. Drill through unconsolidated sediments consisting of $\mathrm{clay}$, silt, sand and gravel (gravel units may include particle sizes to cobble and boulder).

3. Provide sediment samples for characterization.

4. Do not introduce material into the well or induce material movement in the well resulting in contamination of the ground water.

5. Ability to control radioactive contamination encountered.

6. Temporary casing must be removed.

\subsection{ORILLING METHOD ALTERNATIVES.}

Many methods are available for drilling in unconsolidated materials (Oriscoll 1986). Three general methods are commonly used for the installation of ground-water monitoring wells: auger, cable tool, and rotary.

The use of an auger rig and, in particular, a hollow-stem, continuous-flight unit in unconsolidated sediments, is the preferred technique for installation of monitoring wells where possible. A hollow-stem auger quickly bores the hole and the monitoring well is constructed inside the hollow stem. As the flights are removed, the sand pack and seals are al so emplaced through the hollow stem. Besides being generally fast, mobile, and inexpensive to operate, no drilling fluid is used and the formation and ground water are not affected by drilling operations.

The disadvantages of augers include difficulty of use in consol fdated formations and practical limits on depths. Although augers have been able to drill to $300 \mathrm{ft}$ (Driscoll 1986), in general they are limited to depths of approximately 150 feet (Oriscoll 1986; Scalf et al. 1981; Barcelona et al. 1983). Drilling is difficult or impractical in hard rock, coarse gravel or cobble material and in caving formations.

Augers have been tried at the Hanford Site but generally have encountered problems penetrating coarse sediments. Auger equipment are not able to drill through unconsolidated sand units (heaving or flowing sand) which are also encountered. Based on the known capabilities and experience at the Hanford Site, the use of auger equipment is not possible at the 200 Areas. Evaluation of drilling methods witl be limited to the cable tool and rotary methods. 


\subsubsection{Cable Tool Method}

A cable tool rig uses a heavy steel bit suspended on a steel cable which is raised and dropped to chisel or pound a hole through the sediment. The bit can be a solid steel chise? (hard tool) or a hollow tube (core barrel). If the hard tool is used, it breaks up the formation and the material is bailed out of the hole. The core barrel compacts the material inside and is emptied at the surface. Generally, the core barrel can be used in the unsaturated zone; hard tooling is required in the saturated zone. Cable tool drilling in unconsolidated formations, such as are encountered at the Hanford Site, requires the use of a temporary casing to prevent collapse as the hole is advanced.

The cable tool method is almost exclusively used at the Hanford Site when drilling adjacent to waste disposal facilities and excellent control of radioactive contamination is possible. Cable tool equipment has also been used at other locations on the Hanford Site for construction of RCRA monitoring wells similar to the preferred design proposed by this ES. Cable tool equipment is also reasonably available.

The disadvantage of the cable tool method is that it is slower than other methods and has been replaced by the rotary method for most applications. Generally at the Hanford Site, a cable tool rig is capable of drilling a well at an overall rate of $15 \mathrm{ft} /$ day.

\subsubsection{Rotary Methods}

For all rotary methods, a drill bit is rotated at the bottom of the hole to break up the formation. The drill cuttings are then removed by circulation of a drilling fluid. The various types of rotary equipment are divided primarily by the nature of the drilling fluid: mud, water or air. Some rotary equipment is capable of using any of the drilling fluids interchangeably. A bentonite slurry is used with aud rotary equipment to remove the drill cuttings. Water rotary can use any source of water, although water from the aquifer being drilled into (if not contaminated) is preferred. Compressed air is used with air rotary equipment.

Rotary methods are commonly used for drilling water supply wells and for ground-water monitoring wells. Rotary rigs are used occasionally at the Hanford Site, in particular for the drilling of characterization wells for the Basalt Waste Isolation Project. No experience has been obtained in drilling in areas where radioactive contamination is present.

In addition to the drilling fiuid, two different types of drive systems are available: table drive and top head drive. Most rotary equipment use a table drive to rotate the drill string. The table drive is located directly over the borehole at a height of 3 to $4 \mathrm{ft}$. Because of interference by the table drive, it is difficult and impractical to remove temporary casing with table drive equipment. With the top head drive system, the drill string is rotated by the drive, which moves up and down the mast. Special hydraulic equipment is 
available for both driving and pulling temporary casing. Only the top head drive equiparent is considered for drilling at the Hanford Site. (It may be possible to drill the borehole using a table drive rotary and remove the temporary casing using cable tool equipment. The use of the rotary would save time in drilling the borehole.)

Advantages of the rotary method include the capability of drilling deep holes in a variety of diameters. Other advantages include the ability to penetrate a variety of materials and a relativeiy rapid rate of penetration (estimates from 50 to $150 \mathrm{ft} /$ day depending upon conditions).

The main disadvantage with the rotary method is a lack of techniques for the control of radioactive contamination. Orill cuttings are removed from the borehole by the drilling fluid and deposited at the surface. Mud and water rotary equipment collect the drilling fluid in a pit to allow settling of the cuttings and reuse of the fluid. Air rotary equipment generally deposits the drill cuttings at the surface next to the well. If a zone of radioactive contamination is encountered it is potentially possible to contaminate the drilling equipment and an area around the drilling site. This would be especially true of an air rotary. Filter systems may be available or could be designed that would minimize this problem.

A disadvantage with air rotary equipment lies in the potential addition of compressor lubricants to the formation being drilled through, as air is used to removed the drill cuttings. This disadvantage can be overcome through use of air filters and good equipment maintenance.

Another disadvantage with all rotary equipment is the difficulty in collecting representative sediment samples during normal drilling. The geologic formation is broken up by the drill bit and blown up the borehole. Samples collected at the surface are representative only of the average sediment distribution over some poorly defined depth and no information on small scale structure can be obtained. Sediment collected from the unsaturated zone cannot be used for measurement of the moisture content. Core samples can be collected using rotary equipment, but this significantly slows down the drilling rate and increases cost.

Some experience has been obtained using rotary equipment at Hanford. One disadvantage is difficulty in drilling straight boreholes in unconsolidated sediment with cobble- and boulder-size particles. Boulders are not penetrated but pushed to the side, deflecting the borehole. 


\subsection{EVALUATION OF DRILLING METHOD ALTERMATIVES}

\subsubsection{Technical Evaluation}

Criteria 1: Orill borehole to depths between 200 and $600 \mathrm{ft}$.

Either the cable tool method or the rotary method is capable of drilling in Hanford sediments to the required depths. The rotary method may have difficulty maintaining circulation of the drilling fluid in coarse, unconsolidated material.

Criteria 2. Drill through unconsolidated sediment consisting of clay, silt, sand, and gravel to boulder-size particles.

Either the cable tool method or a rotary method is capable of drilling through the required formations. The rotary method may have difficulty in providing a borehole that is straight and plumb in very coarse material.

Criteria 3. Provide sediment samples for characterization.

The cable tool method can provide good sediment and moisture samples in the unsaturated zone that are representative of the surrounding geologic formation using a core barrel. In the saturated zone, sediment samples are collected using a bailer and represent a disturbed material. In the saturated zone, sediment samples collected by rotary equipment and are equivalent to those collected by cable tool equipment using a bailer.

The rotary methods breaks down the formation with a rotating bit and then forces the samples up the casing. The samples are representative only of the average sediment distribution being encountered but are significantly disturbed. Fine structure in the unsaturated zone cannot be observed and moisture samples in the unsaturated zone cannot be obtained. If specialized coring equipment is used with the rotary method, excellent samples can be obtained. However, obtaining the cores significantly reduces the rate of drilling, which greatly increases the cost.

Criteria 4: Introduction of contaminating materials into the well during construction.

For the cable tool method, a small amount of water may be required during in the unsaturated zone to retain sediment samples in the core barrel. Rotary methods require the introduction of a drilling fluid to remove drill cuttings. Compressed air rotary equipment has the least effect on the formation but air must be filtered to remove compressor oils. Water rotary equipment introduce water that may influence the ground-water chemistry. Mud rotary equipment introduces bentonite clay into the formation that may prove difficult to remove during well development and which can have a significant effect on the measured concentration of some aqueous chemical species. 
Criteria 5: Ability to control radioactive contamination encountered.

The cable tool method has been found, through extensive use at the Hanford site, to provide good control of radioactive contamination. Rotary methods have not been used at the Hanford Site in drilling through radioactive contamination, and control of contaninants would probably be difficult without spectally designed equipment. Both mud and water rotary equipment discharge the driling fluid and drill cuttings to a pit. The radioactive contamination would be introduced along with the drilling fluid, potentially contaminating a large volume of solution that would have to be properly disposed of. The air rotary discharges the drill cuttings at the surface next to the borehole. The spread of airborne radioactive contamination is a possibility with air rotary equipment unless suitable filter systems are available or can be developed.

\section{Criteria 6: Temporary casing must be removed.}

Cable tool rigs are capable of pulling back casing, although pulling back in certain formations may be difficult. Standard table drive rotary rigs are capable of pulling casing but only if the tools can be used down the hole. Since the preferred well completion method (see section 7.0) is to complete the monitoring well inside the temporary casing, a standard table drive rotary equipment cannot be used. Rotary rigs equipped with top head drive and a casing hanuer can pull casing from the top of the well.

\subsubsection{Cost and Schedule Evaluation}

Cost and schedule comparison for drilling and completing a standard shaliow well is made between cable tool and air rotary methods. The auger method is not suitable for conditions encountered in the 200 Areas. Cost for the mud or water rotary equipment would be similar to air rotary if temporary casing is used.

Table 4 compares the cost and the time required for drilling and completing a standard shallow well. The borehole is drilled to a depth of $270 \mathrm{ft}, 20 \mathrm{ft}$ below the water table. Estimates are made for the average rate of drilining for the cable tool method and the air rotary method. The estimate for drilling the borehole using the cable tool method is based on experience in well drilling in the 200 Areas. It is assumed that one day is required to develop a well (remova] of fine sediment in the formation near the well screen) drilled by the cable tool method prior to hydrologic testing. The rate at which a well can be completed (placing final screen and casing, pulling back casing and adding seal material) using the cable tool method, is approximate, based on limited experience using cable tool equipment at the Hanford Site. Two days are required for hydrologic testing whether the well is drilled using cable tool or rotary equipment. The rate for drilling the borehole using rotary equipment is an average based on known capabilities. It is assumed that the rotary equipment can complete a well at the same rate as the cable tool method and that 2 days are required to develop the well. Two days are required to develop a well drilled by the air rotary method due to the alteration of the geologic formation by the pressurized drilling fluid. This alteration occurs even with the use of air. The costs are 
for installation of the well and do not include any materials or mobilization charges. Experfence obtained at the nonradioactive dangerous waste landfill indicates that mobilization charges for rotary equipment can add significantly to the cost of the well.

The estimates indicate that the capital cost for construction of a monitoring well may be similar for either the cable tool or the rotary method. However, the cost estimate for the cable tool equipment is based on actual current experience while no comparable information is available for the rotary method. The cost for the rotary method is based on estimated costs and drilling rates. Various factors, particularly the rate at which rotary equipment could complete a well, could significantly change the cost. The advantage of the rotary rig is the significantly faster drilling rate, which would result in savings in expense cost for drilling support.

TABLE 4

COST AND SCHEDULE COMPARISON FOR

DRILLING STANDARD SHALLOH MELL DESIGN USING

CABLE TOOL AND AIR ROTARY METHODS

\begin{tabular}{|c|c|c|}
\hline & $\begin{array}{l}\text { CABLE } \\
\text { TOOL }\end{array}$ & $\begin{array}{c}\text { AIR } \\
\text { ROTARYA }\end{array}$ \\
\hline $\begin{array}{l}\text { ASSUMPTIONS } \\
\text { ORILL } \text { FT/DAY } \\
\text { COMPLETE } \mathrm{FT} / \mathrm{DAY}\end{array}$ & $\begin{array}{l}15 \\
20\end{array}$ & $\begin{array}{l}75 \\
20\end{array}$ \\
\hline $\begin{array}{l}\text { TIME REQUIRED (DAYS) } \\
\text { DRILL TO } 270 \mathrm{FT} \\
\text { DEVELOP AND TEST } \\
\text { COMPLETE }\end{array}$ & $\begin{array}{r}18 \\
3 \\
14\end{array}$ & $\begin{array}{r}4 \\
4 \\
14\end{array}$ \\
\hline $\begin{aligned} \text { TOTAL TIME REQUIRED } & \text { (DAYS) } \\
& \text { (HOURS) }\end{aligned}$ & $\begin{array}{r}35 \\
280\end{array}$ & $\begin{array}{r}22 \\
176\end{array}$ \\
\hline HOURLY $\operatorname{COST}(\$ / H R)$ & $93^{\mathrm{B}}$ & 150 \\
\hline $\begin{array}{l}\text { TOTAL } \operatorname{COST}(\$ \times 1000) \\
\text { COST PER FOOT }(\$ / F T)\end{array}$ & $\begin{array}{l}26.0 \\
96\end{array}$ & $\begin{array}{l}26.4 \\
98\end{array}$ \\
\hline
\end{tabular}




\subsection{PREFERRED DRILLING METHOD}

The cable tool method is the preferred drilling method. The main factor in selection of the cable tool method is the ability to control radioactive contamination. Available evidence indicates that there has been little or no movement of radioactive or hazardous contaminants from the trenches in the LLBG (the LLBG have received mainly radioactive materials). Since some downgradient wells will be located immediately next to trenches, the possibility of encountering radioactive contamination must be considered. of more significance is the location of LLBG near both active and inactive radioactive liquid waste disposal facilities. It would be possible to intersect the radioactive waste plume from a liquid waste site during drilling operations at the LLBG.

The cable tool method is capable of drilling to the depths and through the formations to be encountered. The cable tool method also provides the adequate samples for characterization of sediment distribution and moisture content in the unsaturated zone. The main drawback to the cable tool method is the relatively slow drilling rate but the overall capital cost does not appear to be significantly different (see table 4) than with the rotary method. The cable tool method has the ability to pull casing, aithough the ability to pull the required lengths of casing under the conditions to be encountered needs to be evaluated further.

The advantage of the rotary methods is the faster drilling rate. The requirement for the use of temporary casing and the resultant removal of the casing and completion of the monitoring well to some extent mitigates the drilling advantage. The actual cost of drilling and completing a monitoring well using a rotary method is unknown, since at this time, no RCRA-type monitoring wells have been constructed at the Hanford Site using rotary equipment. The control of radioactive contamination, however, is of prime importance and unless suitable filters or controls are developed, rotary rigs should only be used in carefully selected areas where no contamination will be encountered. In addition, where detailed characterization of the sediment distribution and moisture content is important, the cable tool method is preferred. If a rotary rig is used exclusively, a unit with top head drive and a casing hammer is preferred because of the ability to pull casing. One possible alternative that takes advantage of the faster dritling rate of rotary equipment is to use a table drive air rotary to drill the borehole and use a cable tool rig to complete the well. The limitation of the use of rotary equipment only in selected areas would remain. 


\subsection{MELL COMPLETIOH ALTERHATIVES}

\subsection{CRITERIA}

Requirements for the construction of a monitoring well contained in 40 CFR 265.91(c) specify that "All monitoring wells must be cased in a manner that maintains the integrity of the monitoring well bore hole." "The annular space (i.e., the space between the bore hole and well casing) above the sampling depth must be sealed with a suitable material (e.g., cement grout or bentonite slurry) to prevent contamination of samples and the ground water."

\subsection{WELL-COMPLETION METHODS ALTERNATIVES}

Wells constructed for ground-water monitoring under RCRA must comply with requirements significantly different than wells constructed for other applications such as use as domestic water supply. The drilling of a well disturbs the surrounding sediment, which for a well monitoring a hazardous waste site, can create a pathway for the movement of contaminants along the outside of the monitoring well. The object of the criteria is to construct the monitoring well in a manner that will prevent the migration of contaminants to the sampling zone from the surface or from intermediate zones.

The only method considered that ensures an acceptable seal between the monitoring well and the surrounding geologic formation requires the construction of the monitoring well inside an oversized borehole. The sealing material is then placed into the space between the monitoring well and the borehole wall. This is the method recommended by the EPA (EPA 1985, 1986). If the geologic formation is sufficiently consolidated to maintain an open borehole, the drilling tools can be removed and the monitoring well easily constructed. Where the formation is unconsolidated and will collapse into the borehole, temporary casing must be used to maintain the borehole. The monitoring well is constructed inside the temporary casing. As the sealing materials are added, the temporary casing is removed. Orilling in the unconsolidated Hanford formation and the semiconsolidated Ringold formation requires the use of temporary casing.

Construction of monitoring wells using this technique is new to the Hanford Site. Because of the nature of the geologic materials being drilled through and depths drilled, several problems have been encountered at other RCRA related projects on the Hanford Site. Temporary casings have become stuck at several locations and have broken several times. Past experience however, has indicated that certain procedures and techniques will mitigate these problems. The borehole has to be deepened using the drilling tools with the temporary casing being tapped down into the borehole. The temporary casing cannot be used to drill the borehole. Also, no more than $100 \mathrm{ft}$ of temporary casing of any diameter should be in contact with the geologic formation. As the well is deepened, the temporary casing must be telescoped to smaller diameters with increasing depth. Proper training of the drilling crew will minimize problems.

$$
\text { B. } 28
$$




\subsection{EVALUATION OF WELL-COMPLETION ALTERNATIVE}

No alternatives to the stated completion method are considered.

\subsection{PREFERREO ALTERNATIVE}

The only well-completion alternative is to drill an oversized borehole using temporary casing to support the hole. The monitoring well is constructed inside the borehole and the sand pack and sealing materials are added to the borehole as the temporary casing is removed. 


\subsection{MONITORING WELL DIAMETER ALTERRATIVES}

\subsection{CRITERIA}

The monitoring well provides access to the ground water in order to permit sample collection and measurement of the water level. The following criteria must be met in the selection of monitoring well diameter:

1. The monitoring well diameter must be of sufficient size to install dedicated equipment for purging and sampling.

2. The monitoring well diameter must be of sufficient size to provide access for routine measurement of water level and flexibilfty for use of . additional sampling equipment.

Casing for monitoring wells is generally avallable in diameters ranging from 1-1/4 to 6-in. Larger diameters allow easier access for subsequent sampling activities but cost more in terms of materials and drilling labor. The goal is to select the mininum sizes required to adequately accomplish current sampling and provide flexibility for potential future requirements. Additional clearance may be required to provide access for other equipment necessary for water level measurements. Evaluation of alternatives for both purging/sampling equipment and water-level measurement are discussed in the following sections.

\subsection{SAMPLING/PURGING METHODS AND EQUIPMENT ALTERNATIVES}

The primary objective of the monitoring well is to provide access to the ground water in order to permit required sample collection and water-level measurements. Sample collection requires both purging the monitoring well of stagnant water and the actual collection of samples.

In order to purge a well, it is necessary to remove the standing water unti1 the well is thoroughly flushed and contains fresh formation water. The amount of purging is dependent upon many factors and several common procedures are used (Ford et al. 1984; MeNabb and Mallord 1980). The procedure used at the Hanford Site requires the purging of 3 bore volumes and the monitoring of $\mathrm{pH}$ and specific conductivity until these parameters stabilize.

Requirements for sampling equipment depend on the contaminants being analyzed. Since it may be necessary to sample for a variety of contaminants, it is convenient to have the option of using several methods and have the diameter of the monitoring well selected accordingly.

Methods considered for purging and/or sampling ground water from monitoring wells include bailer, bladder pumps, piston pumps, and submersible pumps. In some cases, purging and sampling may be accomplished using the same equipment.

Bailers are probabiy the simplest and most flexible method available for collecting ground-water samples. Bailers generally consist of a long tube with a 
ball valve on the bottom. The bailer is lowered down the well into the ground water, filled, and pulled back out. Bailers provide good water samples for most types of components and can be used in a 1-1/4 in. diameter well. Because of the depth to ground water, use of a bailer at the Hanford Site for both purging and all sampling would be tedious and labor intensive.

Bladder pumps consist of a flexible tube inside a long rigid housing with check valves to control the flow of water and pressurizing gas. Hydrostatic pressure forces water into the bladder through a check valve. Compressed gas then pressurizes the space between the housing and the bladder, squeezing the bladder and forcing the water out a second check valve and into the discharge line. The pressure is then released and the cycle repeated. Because the ground-water sample is not agitated, use of bladder pumps are preferred for most sampling requirements and espectally for volatile organic species. Bladder pumps will fit inside a 2-in. diameter well. The operation of the bladder pump is affected by the pumping head. At depths to ground water between 200 and $300 \mathrm{ft}$, the discharge rate of a bladder pump will be significantly less than 1-gal/min. and some designs will not work.

Piston pumps use a piston moving inside a rigid housing instead of a flexible bladder to squeeze the water into the discharge line. Compressed air or mechanical motion provided by a cable or rod provides power for the piston. Piston pumps will generally fit inside a 2-in. diameter well. Performance of piston pumps is similar to bladder pumps. However, certain designs using mechanical motion are reported capable of discharge volumes of 1 to $2 \mathrm{gal} / \mathrm{min}$. at depths between 200 and $300 \mathrm{ft}$. Use of piston pumps can be an acceptable method for sampling volatile organic species if the cycling rate can be reduced to minimize agitation of the sample.

Submersible pumps are commonly used to supply water from domestic wells. These pumps use an impeller to force water to the surface. Submersible pumps are available that will fit inside a 4-in. diameter well. Discharge rates are dependent upon the horsepower of the electric motor, but a 3-hp (4-in. diameter) pump pumping against a hydraulic head of $250 \mathrm{ft}$ would be capable of discharging approximately $25 \mathrm{gal} /$ min. Because the impeller agitates the ground-water samples, submersible pumps may not be suitable for all sampling.

\subsection{WATER-LEVEL MEASUREMENT EQUIPMENT ALTERNATIVES}

A number of methods are available for measuring water levels and inciude steel tape, electrical tape, air lines, and pressure transducers (see Driscoll) 1986). At the Hanford Site, routine water-level measurements are taken using a steel tape, supplemented with an electrical tape. Pressure transducers are occasionally used during aquifer testing. Steel tape is the most accurate and precise method available for measuring water level to measurements of $0.01 \mathrm{ft}$. other methods are presently limited to measurement of $0.1 \mathrm{ft}$. 


\subsection{EVALUATIOH OF ALTERNATIVES}

\subsubsection{Technical Evaluation}

Criteria 1: The monitoring well diameter must be of sufficient size to install dedicated equipment for purging and sampling.

In order to obtain samples, the well must be purged and accessed to allow introduction of the required sampling equipment. Consideration is given primarily to 2-in. and 4-in. inside diameter casings. Larger diameter casings may have to be considered where dedicated sampling equipment and in particular a submersible pump is used (EPA, 1986).

For the deep-well design, $200 \mathrm{ft}$ of water in the casing must be purged for each well volume. For a $2-i n$. diameter casing, purging of 3 well volumes would require the removal of approximately $100 \mathrm{gal}$ of water. For a 4-in. diameter casing, purging would require the removal of approximately $400 \mathrm{gal}$ of water.

Bladder pumps and bailers are expected to have practical discharge rates less than $1 \mathrm{gal} / \mathrm{min}$. with a depth to the water table of $250 \mathrm{ft}$. It would require at least 1 hour and 20 minutes to purge the required 3 well volumes from a 2 -in diameter well, using either of these methods. This is not an acceptable time. However, either a bladder pump or a bailer might be used to sample the ground water. Baflers would require a minimum 1-1/4- in. diameter well; bladder pumps would require a minimum $2-i n$. diameter well.

Piston pumps may operate more efficiently at greater depths than bladder pumps but the discharge rate is still reduced. Discharge rates of 1 to 2 gal/min. may be possible with pumping heads of 200 to $300 \mathrm{ft}$. Piston pumps could be used for both purging and sampling if the required capacity is demonstrated. Piston pumps would require a minimum 2-inch diameter well.

Submersible pumps have the capacity to purge a deep well, but require a 4-in. diameter casing at a minimum. Although a submersible pump can be used for some sampling, it may not be suitable for most organic contaminants unless special equipment and sampling procedures are implemented.

One limitation of using a submersible pump in a 4-in. diameter casing is that the diameter of current1y available submersible pumps constructed of nonreactive materials is approximately 3-3/4 in. There is insufficient clearance between the well casing and the submersible pump for additional sampling equipment to access the volume beneath the pump. Using a casing diameter larger than 4-in. would provide sufficient clearance for sampling equipment, but due to the depth to the bottom of the aquifer, a single sampling pump, depending upon design, may not be capable of pumping from that depth. Although it may be possible to run several sampling pumps in series (EPA 1985), such a system would have increased complexity and reduced reliability. The larger diameter casing would also increase the cost of the well installation. e.g., 5-in. diameter casing costs 50\% more than a 4 -in. casing (Table 5).

$$
\text { B. } 32
$$


If samples are taken above the subnersible pump, the potential exists for the volume of water above the subinersible pump to remain stagnant during purging. It would be necessary to purge this volume with the sampling equipment prior to the start of sampling. Although this is not an ideal approach, it may be an acceptable alternative.

For the shallow-well design, only $15 \mathrm{ft}$ of water in the casing must be purged for each well volume. For a 2-in. diameter casing, purging 3 well volumes would require the removal of approximately $7 \mathrm{gal}$ of water. For a 4-in. diameter casing, purging 3 well volumes would require the removal of approximately $30 \mathrm{gal}$ of water.

A bailer would be capable of purging a 2-in. dianeter well. The operation would be tedious and labor intensive because of the depth to the water table. The potential for contamination of a sample would be high due to the number of times the bailer would have to be raised and lowered in each well. Purging a 4-in. diameter well with a bailer would not be practical.

Bladder pumps with designs capable of operating at the depths required will have significantly reduced discharge capacities. However, if a discharge rate of $1 \mathrm{gal} / \mathrm{min}$ is possible, a bladder pump could be used to purge and sample a shallow we11.

Piston pumps may have the capacity for both purging and sampling from the depths required. Discharge rates would be reduced, but rates of $1 \mathrm{gal} / \mathrm{min}$. or greater would be adequate for the requirements.

Submersible pumps would have the capacity to purge a shallow well very quickly but would require a minimum 4.0-in. internal diameter well. A submersible pump may not be suitable for the collection of certain types of samples.

Criteria 2: The monitoring well diameter must be of sufficient size to provide access for routine measurement of water level and flexibility for use of additional sampling equipment.

Experience has shown that even with existing 6- and 8-in. diameter wells with dedicated submersible pumps, water-level measuring equipment and bajlers have become stuck. The monitoring we11s, pump discharge lines, and electrical connections are not perfectiy straight or centered. Pinch points occur that will catch any piece of equipment which is raised or lowered in the well. The larger well diameter mitigates but does not eliminate the problem.

Obtaining water-level measurements in a 2-in. diameter well with a dedicated pump would be very difficult, if not impossible, without removal of the pump. For a 4-in. diameter well with dedicated pump, water-level measurements could be made and sufficient clearance would be available for additional sampling equipment. The use of $4-i n$. diameter casing could be improved significantiy if a 
1-1/4-in. diameter drop tube was installed inside the well. The drop tube would mun from the top of the well into the water and would provide unobstructed access for water-level measurements and use of a bajler.

\subsubsection{Cost and Schedule Evaluation}

Table 5 shows the cost per $10-\mathrm{ft}$ section of type 304 stainless steel flush jointed casing of a type commonly used for construction of ground-water monitoring wells. A significant increase in cost is incurred for any increase in casing size. The 4-inch casing is over twice the cost of 2-in. casing; the 5inch casing is $50 \%$ more expensive than the 4-in. casing. For the $250 \mathrm{ft}$ of casing, which ts sufficient for the standard design shallow monitoring well, the list price for 2-in. castng is $\$ 2,165$, for $4-i n$. casing the cost is $\$ 4,544$, for 5-in. casing the cost is $\$ 6,832$.

Table 5

Cost for Type 304 Stainless Steel Flush Joint Casing in 10-Foot Lengths

(Johnson Division Environmental Catalog 1985)

$\begin{array}{ccccc}\begin{array}{c}\text { PIPE } \\ \text { SIZE }\end{array} & \begin{array}{c}\text { PIPE } \\ \text { Outside } \\ \text { Diameter } \\ \text { (in.) }\end{array} & \begin{array}{c}\text { FITTING } \\ \text { Inside } \\ \text { Diameter } \\ \text { (in.) }\end{array} & \text { PRICE } & \begin{array}{c}\text { \% DIFFERENCE } \\ \text { COMPARED TO } \\ 1-1 / 4 \text { in. }\end{array} \\ 1-1 / 4 & 1.660 & 1.380 & \$ 66.15 & -- \\ 2 & 2.375 & 2.067 & \$ 86.60 & 31 \\ 4 & 4.500 & 4.026 & \$ 181.75 & 175 \\ 5 & 5.563 & 5.047 & \$ 273.30 & 313 \\ 6 & 6.625 & 6.065 & \$ 367.50 & 456\end{array}$

While the savings-in-materials costs for casing may appear significant, material cost accounts for approximately $10 \%$ of the total capital cost for construction a monitoring well. The relatively small cost savings available should not influence the technical decisions with regards to the diameter of the monitoring wel1.

Casing material of the diameters identified in table 5 are readily available. Assembly of the well in the field would not be significantly impacted by larger diameter casing except for the heavier weight of these materials. 


\subsection{PREFERRED ALTERMATIVE}

The preferred well diameter is determined by the requirements of the purging and sampling equipment. The assumption is made that the purging and sampling equipment selected will be dedicated to each well. The potential for cross contamination is greatly increased if equipment has to be cleaned in the field before use at each well. Furthermore, the time required to install and remove equipment would greatly increase the operating cost of the system. In addition, although use of a bailer for all purging and sampling is considered unacceptable, the option to use a bailer is considered desirable.

The preferred well diameter for the shallow well design is 4-in. This is considered the mintmum technically useful size. Larger diameters would provide greater flexibility in obtaining samples or measurements but would significantiy increase the cost of well construction. Smaller diameters would not provide sufficient clearance for routine water level measurements and clearance for installation of a submersible pump is considered a necessary option at this time.

The minimum technically useful well diameter for the deep well design is 4-in. Only submersible pumps have the demonstrated capacity to purge deep wells and the use of a submersible pump requires a well with a minimum 4.0-in inside diameter. Since the deep wells are being constructed, in part, to evaluate the need for monitoring the unconfined aquifer at depth, the 4-in. diameter is an acceptable compromise at this time. If the need for additional deep monitoring wells is identified, the design for the deep wells should be reevaluated. For routine ground-water monitoring with a deep well design, the preferred well diameter would probably be larger than 4 -in. to provide proper installation of additional sampling equipment.

The main uncertainty in the evaluation of the monitoring well diameter is identification of pumping equipment with adequate discharge capacity. While bladder pumps are normaliy preferred for sampling, at the depths to ground water encountered, bladder pumps will either not function or discharge at such a reduced rate as to be impractical for purging and possibly sampling. Piston pumps, especially those where mechanical action is provided by a solid rod, have potential discharge rates of 1 to $2 \mathrm{gal} / \mathrm{min}$. at the depths required. This volume would be adequate for both sampling and purging the shallow well design. However, these pumps are relatively new and their performance and reliability have not yet been demonstrated. A test of available pumps is being planned as part of this project to identify suitable equipment but has not been conducted at present. As a result, it is considered necessary to provide adequate clearance for installation of a submersible pump. It should be noted, however, that a smaller diameter pump would not result in a preferred smaller diameter for the well. Wells smaller than 4-in still do not provide adequate clearance for routine water level measurements and limit flexibility in sampling. The preferred monitoring well would still use 4 -in. casing with a dedicated 2-in. diameter sampling/purging pump. 
It should also be emphasized that the installation of a submersible pump in a 4-in. well severely restricts the ease with which other equipment can be installed. The discharge column and electrical wires will limit, and may preclude, adequate clearance for installation of a separate sampling pump and for access for water level measurement. Novel designs and special care may be required in order to assure adequate performance of 4-in. wells if submersible pumps are used. 
RE-ES-037 ReV. 0

\subsection{BOREHOLE DIAMETER AMD CLEARAMCE ALTERMATIVES}

\subsection{CRITERIA}

In order to complete a monitoring well using the preferred method (see. section 6.0) sealing material and an artificial sand pack must be introduced between the temporary casing and the monitoring well. The preferred diameter of the monitoring well is $4-i n$. The diameter of the temporary casing must meet the following criteria:

The inside diameter of the temporary casing compared to the outside diameter of the monitoring well will provide sufficient clearance for the introduction and proper placement of the artificial sand pack and the sealing materials.

\subsection{ALTERNATIVES}

Two methods are commonly used to introduce the artificial sand pack and the sealing material into the space between the temporary casing and the monitoring well: pouring materials down the annulus, and tremie pipe. Either method has certain advantages and disadvantages. Both methods may be used, depending on the material to be placed. The use of the tremie pipe, is required, however, if the material being added is a slurry such as a cement grout or bentonite slurry.

\subsubsection{Pouring Materials}

Using this method, the material is simply poured into the annular space between the monitoring well and the temporary casing. The material is allowed to fall down the well into place. Only dry granular material can be poured; it is not possible to place slurries or grout by pouring. Additional problems include bridging of material between the casing and the well, and segregation of material on the basis of size.

Bridging of material occurs across narrow spots between the casings, potentially preventing all the material from reaching the desired location. Generally a 3 - to 5-in. difference between the outside diameter of the monitoring well and the inside diameter of the temporary casing is required to minimize bridging (EPA 1986). Problems with bridging can also be minimized, by careful measurement of the depth of material added, tamping the material down, and by washing dry material down the borehole if the material is being placed above the water table.

Emplacement of slurries or grouts must be accomplished using a tremie pipe. Bridging will easily occur with slurries or grouts resulting in an inadequate and unacceptable annular seal. These materials also do not have a sufficient density difference to sink in water. If poured down the well, slurries will not sink, will collect at the water table, and will build up toward the surface.

$$
\text { B. } 37
$$


Segregation is a problem where granular material settles through a column of water. Larger particles settle faster. A 1/8-in. diameter grain will settle in one-fourth the time required for a 1/16-in. diameter grain (Driscoll 1986). The longer the water column, the more distinct the segregation.

\subsubsection{Tremie Pide}

A tremie pipe consists of small-diameter threaded pipe placed in the space between the temporary casing and the monitoring well. The bottom of the tremie pipe is positioned at the approximate depth the material is to be placed. Depending upon the material's texture, it can then either be poured or pumped down the pipe. The tremie pipe method provides good control on the placement of all materials. The tremie pipe is also the only means of placing a bentonite slurry or cement grout below the water table.

Generally, a tremie pipe of 2-in. diameter or greater is recommended (Driscoll 1986). Although smaller diameters can be used, placement of materials is slower. The smaller diameter reduces the rate at which material can be introduced. The smaller diameter also results in greater frictional losses for flow, further reducing the rate at which material can be introduced. Finally, the smaller diameter increases the potential for bridging in the pipe.

Experience at the Hanford Site indicates that a tremie pipe with an internal diameter as small as l-in. would be adequate for placing of seal material.

\subsection{EVALUATION OF ALTERNATIVES}

\subsubsection{Technical Evaluation}

Bentonite based grout is the preferred primary sealing material. It avoids the $\mathrm{pH}$ problems associated with portland cement based grouts and is easier to work with than bentonite slurries or dry bentonite. Since slurries have to be placed with a tremie pipe, the same minimum clearance must be provided for both shallow and deep well designs.

In evaluating the requirements for clearance, it is assumed that a 4-in. inner dianeter casing (see section 8.0) manufactured of type 304 stainless stee] (see section 5.0) is preferred for construction of the monitoring well. The outside diameter of 4-in. inner diameter casing is 4.5-in. (Table 2).

Construction of a monitoring well is not an operation involving close tolerances. The monitoring well will not be centered nor is the temporary casing and well perfectly straight or plumb. In addition, welding of sections of temporary casing reduces the effective inner diameter of the temporary casing. Sufficient tolerance for the dimensions must be allowed to account for this lack of precision.

Temporary casing is commonly available in 6-, 8-, and 10-in. inner diameter which, if the monitoring well is centered, would provide clearance of approximately $0.75-\mathrm{in} ., 1.75-\mathrm{in.}$, and 2.75-in. respectively. The use of 10-in. 
temporary casing would provide a clearance of $2.5 \mathrm{in}$. or greater, permitting use of a 2-1n. diameter tremie pipe as reconmended by Driscoll (1986). The use of 8-in. temporary casing would provide clearance of $1.75-i n$. under ideal conditions, which would require the use of a tremie pipe with an outer diameter of 1.5-in. or less. Al though this less than optimum size would result is some difficulty in pumping the grout, experience indicates that this would be an acceptable alternative. The use of $6-i n$. temporary casing would not provide sufficient clearance for the use of any tremie pipe.

\subsubsection{Cost and Schedule Evaluation}

Consideration was given to $10-i n$. and 8 -in. inside diameter temporary casing to provide clearance for use of a tremie pipe. The cost of this size casing, however, is not the oniy cost consideration. To aid in the pull back of temporary casing, the casing must be telescoped (reduced) to smaller diameters with depth. Experience at the Hanford Site indicates that the temporary casing must be telescoped at least every $100 \mathrm{ft}$ to minimize problems during pull back. As a result, for the shallow well design drilled to a depth of $270 \mathrm{ft}$, the casing must be reduced twice. For a minimum 8-in. temporary casing at the bottom of the borehole, 12-in. casing must be used from the surface to the $100 \mathrm{ft}$ depth, the casing is reduced to 10 -in from $100 \mathrm{ft}$ to $200 \mathrm{ft}$, and finally the casing is reduced to $8-\mathrm{in}$. from $200 \mathrm{ft}$ to $270 \mathrm{ft}$. Using 10-in temporary casing to provide the minimum clearance results in larger diameter casings for the entire well. A 16-in. diameter casing is required from the surface to $100 \mathrm{ft}$ while 12 -in. casing is required from $100 \mathrm{ft}$ to $200 \mathrm{ft}$. (Because of a change in the way pipe dimensions are measured for pipe sizes above 12-in., 14-in. casing does not provide adequate clearance for the required use.) Although temporary casing can be recovered and reused, it is assumed there will be $10 \%$ to $20 \%$ operational loss.

The cost of using larger diameter casing is not limited soleiy to the price of casing. Larger casing requires a larger borehole. The cost of drilling the borehole can be related to the hole diameter. As a general "rule of thumb", drilling costs at the Hanford Site are approximately $\$ 5$ per diameter inch per foot drilled. For example, drilling an 8-in. hole costs approximately $\$ 40$ per foot, while a 10-in. hole costs approximately $\$ 50$ per foot.

Other costs are incurred drilling larger diameter wells. These costs include additional sealing materials and schedule costs because a larger diameter hole takes longer to drill (which is why it costs more). However, for the most part, the major cost difference is related to the cost of drilling and temporary casing. Table 6 compares the difference of these major costs for the "10-in." and the "8-in." boreholes for installation of a standard design shallow 4-in. monitoring well. To account for the reuse of the temporary casing, it is assumed that only $20 \%$ of the total length of each casing size used has to be purchased new.

$$
\text { B. } 35
$$


Table 6

Comparison of Cost for Clearance AlternativesStandard Shallow Hell Design

Assumptions: Drilled to $270 \mathrm{ft}$

Casing telescoped at 100 and $200 \mathrm{ft}$

\begin{tabular}{|c|c|c|c|c|c|}
\hline ITEM & $\begin{array}{c}\operatorname{cosT} \\
(S / F T)\end{array}$ & $\begin{array}{c}10-i n . f i \\
\text { QUANTITY } \\
\text { (FT) }\end{array}$ & $\begin{array}{c}\text { 1al size } \\
\text { cost } \\
(\$)\end{array}$ & $\begin{array}{c}8-i n . f \\
\text { QUANTITY } \\
\text { (FT) }\end{array}$ & $\begin{array}{c}\text { al size } \\
\text { COST } \\
\text { (FT) }\end{array}$ \\
\hline $\begin{array}{l}\text { Drill 16-in. hole } \\
\text { 16-in. casing }\end{array}$ & $\begin{array}{l}80 \\
20\end{array}$ & $\begin{array}{c}100 \\
20^{a}(100)\end{array}$ & $\begin{array}{r}8,000 \\
400\end{array}$ & $\begin{array}{l}\text { NA } \\
\text { MA }\end{array}$ & +- \\
\hline $\begin{array}{l}\text { Drill 12-in. hole } \\
12-\text { in. casing }\end{array}$ & $\begin{array}{l}60 \\
15\end{array}$ & $\begin{array}{c}100 \\
40^{\mathrm{a}}(200)\end{array}$ & $\begin{array}{r}6,000 \\
600\end{array}$ & $\left|\begin{array}{c}100 \\
20^{\mathrm{a}}(100)\end{array}\right|$ & $\begin{array}{r}6,000 \\
300\end{array}$ \\
\hline $\begin{array}{l}\text { Drill 10-in. hole } \\
10-\text { in. casing }\end{array}$ & $\begin{array}{l}50 \\
12\end{array}$ & $\left|\begin{array}{c}70 \\
54^{\mathrm{a}}(270)\end{array}\right|$ & $\begin{array}{r}3,500 \\
648\end{array}$ & $\begin{array}{c}100 \\
40^{a}(200)\end{array}$ & $\begin{array}{r}5,000 \\
480\end{array}$ \\
\hline $\begin{array}{l}\text { Drill } 8 \text {-in. hole } \\
\text { 8-in. casing }\end{array}$ & $\begin{array}{l}40 \\
10\end{array}$ & $\begin{array}{l}\text { NA } \\
\text { NA }\end{array}$ & $\begin{array}{l}-- \\
--\end{array}$ & $\begin{array}{c}70 \\
54^{a}(270)\end{array}$ & $\begin{array}{r}2,800 \\
540\end{array}$ \\
\hline
\end{tabular}

a The number of feet of temporary casing shown is new casing and assumes that $20 \%$ of the casing has to be replaced for each well. The total amount of temporary casing required to construct the borehole is shown in parentheses.

The result of the cost estimate in Table 6 indicates that providing an additional 2-in. of clearance increases the direct cost of drilling the shallow monitoring well by at least $\$ 4,000$ or approximately $25 \%$. The cost increase (25\%) for the deep monitoring well design would be comparable.

\subsection{PREFERRED ALTERNATIVE}

The preferred alternative is to use 8 -in inside diameter temporary casing at the completion depth and telescope the casing as required from the surface. It is recognized that the clearance available between the monitoring well and the temporary casing will require the use of a tremie pipe with a diameter less than the optimal 2-in. recommended. This will slow the emplacement of the materials to some extent but should not affect the confidence in the resulting seal. The significantly increased cost resulting from the use of larger diameter casing and boreholes cannot be justified unless significant problems are encountered. 


\subsection{REFERENCES}

BARCELONA, M. J., J. P. Gibb, and R. A. Miller, 1983, A quide to the Selection of Materials for Monitoring Well Construction and Ground-Water Samoling, SWS Contract Report 327, I11 inois State Water Survey, Champaign, I11inois.

CODE OF FEDERAL REGULATIONS, Title 40, Part 265, Environmental Protection Agency Interim Status Standards for Owners and Operators of Hazardous Waste Facilities, U. S. Government Printing Office, Hashington, DC.

ORISCOLL, F. G., 1986, Groundwater and Wells, Second Edition, Johnson Oivision, St. Paul, Minnesota.

FORO, P. J., P. J. Turina, and O. E. Seely, 1984, Charactertzation of Hazardous Waste Sites - A Methods Manual: Volume II Available Sampling Methods. Second Edition, EPA-600/4-84-076, U. S. Environmental Protection Agency, Las Vegas, Nevada.

GIBBS, J. P., R. M. Schuller, and R. A. Griffin, 1981, Procedure for the Collection of Representative Water Qual ity Data from Monitoring Hells.

GRAHAM, M. J., 1981, Hydrology of the Separations Area, RHO-ST-42, Rockwel1 Hanford Operations, Richland, Washington.

McNA8B, J. F., and G. E. Mallord, 1980, Introduction to Subsurface Microbiology and Sampling Problems, Society for Microbiology Annual Meeting, Miami Beach, Flortda.

SCALF, M. R., J. F. MCNabb, W. J. Dunlap, R. L. Cosby, and J. Fryberger, 1981, Manual of Ground-Hater Sampling Procedures, U. S. Environmental Protection Agency, Ada, Okl ahoma.

SCHATZ, A. L., and E. J. Jensen, 1986, Hanford Site Hater Table Map - June 1986, H-2-38396, Revision 21, Rockwell Hanford Operations, Richland, Washington.

TALLMAN, A. M., K. R. Fecht, M. C. Marratt, and G. V. Last, 1979, Geology of the Separation Areas, Hanford Site. South-Central Washington, RH0-ST-23, Rockwell Hanford Operation, Richland, Washington.

U. S. Environmenta1 Protection Agency, 1985, RCRA Ground-Water Monitoring Technical Enforcement Guidance Document - DRAFT.

U. S. Environmenta] Protection Agency, 1986, RCRA Ground-Water Monitoring Technical Enforcement Guidance Document, OSWER-9950.1.

Washington Department of Ecology, 1986, Ecology No. OE 86-133 PCHB No. 86-44. Consent Agreement and Compli ance Order, October 1, 1986. 
WENTHORTH, C. K., 1922, A Scale of Grade and Class Terms for Clastic Sediments, Journal of Geology, v. 30. 
APPENDIX C

WELL SPECIFICATIONS--STATEMENT OF WORK 
APPENDIX C

WELL SPECIFICATIONS (STATEMENT OF WORK)

Spectfication JAJ 1915-1

Project No. B-678

CONSTRUCTION SPECIFICATIONS

GROUND-WATER MONITORING WELLS

HANFORD 200-EAST AREA LOW-LEVEL BURIAL GROUNDS

AND RETRIEVABLE STORAGE UNITS

Prepared by

U.S. Department of Energy

Pacific Northwest Laboratory

Operated by

Battelle Menorial Institute

PNL

Project Manager

Facilities Engineering

RHO

Project Engineer

Construction Engineer
Date

Date

Date

\section{C.I}




\section{TABLE OF CONTENTS}

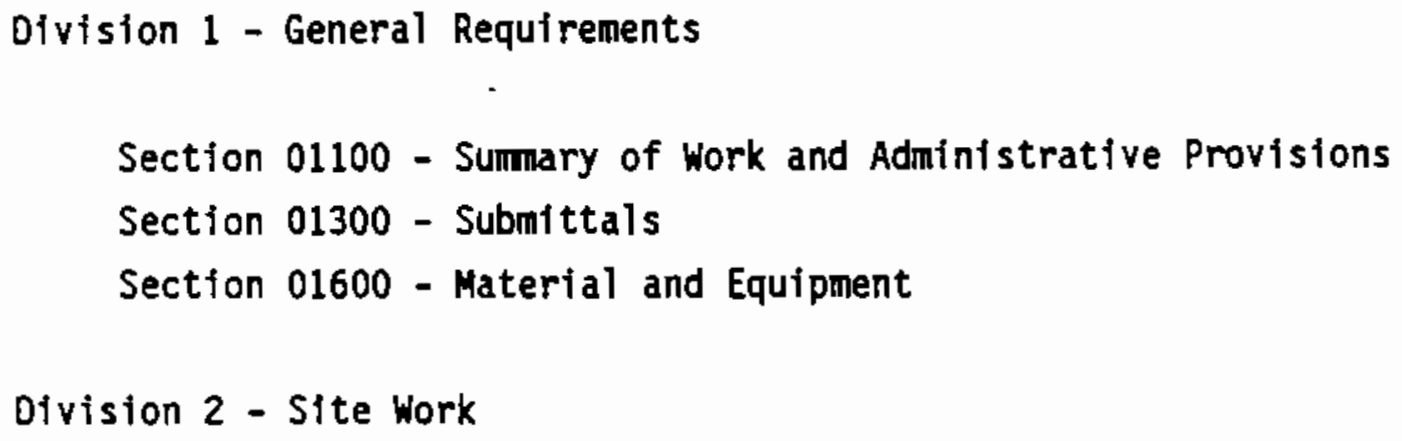




\section{SECTION 01100 \\ SUMMARY OF WORK AND ADHINISTRATIVE PROVISIONS}

$$
\text { PART } 1.0 \text { - GENERAL }
$$

\subsection{Work Included}

The work under this contract includes the furnishing of all labor, material, transportation, tools, supplies, plant, equipment, and appurtenances, unless hereinafter specffically excepted, necessary for the complete and satisfactory construction and testing of 16 shallow monitoring wells. The effort and materials required for this work include, but are not necessarily limited to:

A. Construction and testing of sixteen shallow monitoring wells (approximately $330 \mathrm{ft}$ deep).

B. Loading, hauling, and using Owner furnished material as needed from the designated storage area for construction of the monftoring wells.

c. Hauling, loading, cleaning, and storing any unused owner furnished material to the designated storage area.

D. Furnishing and using bailers, pumps, and surge blocks to develop monitoring welis.

E. Furnishing and using submersible and/or line-shaft turbine pumps for aquifer tests.

F. AIl other related items needed for a complete and proper installation and testing of the monitoring wells in accordance with the intent of the specifications. 
G. Pouring and finishing a concrete pad ( $4 \mathrm{ft} \times 4 \mathrm{ft} \times 4 \mathrm{in}$ ) around each completed monitoring well, placing a brass plate in the concrete pad, and instaliting guard posts.

\section{1 .1 S1te Maps}

Figure 1 (attached) shows the approximate well locations, the designated storage areas of. JAJ furnished material, and locations of approved water sources.

All drilling sites are located in the 200-East Area or immediate vicinity within the Hanford Site in the State of Washington, approximately 30 road miles north of Richland. Each well site is clearly marked and labeled in the field with a stake painted fluorescent orange. Access to the drilling locations within the area shown in Figure 1 is primarily by gravel covered or unimproved dirt roads.

\subsubsection{Site Geology and Well Configuration}

The contractor should anticipate drilling in unconsolidated to consolidated materials, consisting of clay, silt, sand, gravel, cobbles, and boulders. These materials were deposited in fluvial and glaciofluvial environments and may be cemented, forming hardened layers of variable thickness. Figure 2 shows the general configuration of the completed shallow and deep monitoring wells.

\section{1 .3 Other Conditions}

Low levels of radiological and chemical contamination may be encountered during drilling. JAJ will provide routine monitoring of the drili cuttings and fluids penetrated in each borehole. Radiation and organic vapor monitoring will be provided during all drilling to assure safety of all workers. In the event contamination is encountered, protective clothing will be provided to the contractor by JAJ. 


\subsection{Qualifications of Contractor}

All drillers shall be licensed well drillers in the State of Washington and have a minimum of five years cable tool drilling experience using both drive barrel and hard tool.

The Contractor will supply documentation of wells he has completed for Resource Conservation and Recovery Act (RCRA) ground-water monitoring and accepted by the Washington State Department of Ecology, the Environmenta] Protection Agency, or other regulatory agency.

\subsection{Work Sequence}

A well that is started shall be constructed in a continuous operation.

The Contractor shall coordinate his work so the aquifer testing of paired wells can be performed as described in Paragraph 3.2.3 of Section 02011.

\subsection{Well Site Inspections}

The site geologist will be present to perform the inspection necessary to ensure the proper installation of the monitoring wells in strict accordance with all specifications contained in this contract.

\subsection{JAJ-Furnished Products}

\section{A. Stainless Steel Screen (8 inch telescope size)}

Stainless steel screen $w f 11$ be new, 8 inch telescope size, Type 304 stainless steel, $10 \mathrm{ft}$ long. The screens wfll be of the continuous slot, wire-wound design with flat stainless steel plates, with bailer hook, factory welded to the bottom. The slot size will be 0.030 inch. The screens will 
have been factory cleaned and separately wrapped in protective polyethylene for shipment.

\section{B. Stainless Steel Screen ( 4 inch)}

Stainless steel screen will be new, 4 inch nominal diameter, Type 304 stainless steel. The screens wlll be of the continuous slot, wire-wound design. Lengths of screen will be furnished with flat stainless steel plates, with bailer hook, factory welded to the bottom of each screened interval. Additional lengths of screen will be furnished with threaded end fittings. The end fittings will be double entry stub ACME flush screw threads. The screen slot size will provide a minimum open area of $11 \%$ with 0.020 inch slot openings.

Screens will have been factory cleaned and individually and separately wrapped in protective polyethylene prior to shipment. The well screen will be manufactured by Johnson Division, UOP, St. Paul, Minnesota, or an approved equal.

\section{c. Centralizers}

Centralizers will be 304 stainless steel. Centralizers will be of such a design that minimal interference with placement of well completion materials via the tremie pipe method will be experienced.

\section{Stainless Steel Casing (4 inch)}

Stainless steel casing will be new, 4 inch nominal diameter, Type 304 stainless steel. The pipe will be Schedule 5, meeting ASTM specification A312 or A778. The individual segments of stainless steel casing will be flush coupled the same as the well screen. Ends of the casing shall be Schedule 40 to provide adequate wall thickness for threaded joints. Casing will have been steam cleaned and allowed to air dry prior to sealing and packaging at the factory. Casing will be furnished in lengths of $10 \mathrm{ft}, 5 \mathrm{ft}$, and $2 \mathrm{ft}$. 


\section{E. Artificial Sand Pack}

Artificial sand pack materlal will consist of kiln dried quartz (silica) sand, 0.023 to 0.032 inch (U.S. sieve size 20 to 30 ) in diameter, rounded and spherical grains, packaged in sacks.

\section{F. Bentonite Pellets}

Bentonite pellets will be composed of comercially avallable pellets, volclay Pellets or approved equal, 0.25 inches in diameter, in buckets.

\section{G. Bentonite Grout}

Volclay bentonite-based grout (dry $m i x$ ), packaged in sacks.

\section{H. Granular Bentonite}

Granular bentonite will be composed of coarse granular bentonite crumbles, packaged in sacks.

\section{Sack Crete}

Provided in sacks.

J. Portland Cement

Provided in sacks

K. Well Cap

Each well will have a locking, removable, stainless steel cap designed to slip over the permanent stainless steel casing and to provide adequate clearance for the dedicated sampling pump hardware. 
L. Brass Survey Marker

M. Sample Jars

Glass Jars as required.

0. Hydrologic Sampling Equipment

P. $\quad$ Orive Shoes

Q. Carbon Steel Casing

ASTM A53 Grade B, Schedule 40 seamed pipe. Pipe will be initially in 20

ft Joints. Diameters provided will be $16 \mathrm{in,} 14 \mathrm{in}, 12 \mathrm{in}, 10$ in and $8 \mathrm{in}$.

R. Guard Posts

Guard posts will be 4 in diameter schedule 40 pipe, $6.5 \mathrm{ft}$ long.

S. Paint 


\section{SECTION 01300}

SUBMITTALS

PART 1.0 - GENERAL

\subsection{Work Included}

This section lists submittais required of the Contractor.

\subsection{Submittais}

\subsubsection{Information to be Submitted with Bid Package}

A. Contractor Washington State Drillers License

Submit copies of licenses for Contractor and drillers.

\section{B. Driller Method and Equipment}

Subnit a description of the equipment to be used and the methods to be used to construct the welis, including methodology of setting and removing temporary casing.

\section{c. Personnel Qualifications}

Furnish resumes for all supervisors, drillers, and helpers that will be on the fob site. State specificaliy the fob experience relating to the drilling of monitoring wells that have been done and accepted by the U.S. Environmenta? Protection Agency, the Washington State Department of Ecology, or other regulatory agency. 


\subsubsection{Performance Submittals}

A. Construction Schedule

Submit an initial construction schedule within 10 days of award of contract. Revise the schedule as needed to meet the contract completion date.

B. Drilling Logs

Submit the signed and completed logs as specified in Section 02011.

\section{Flow Meter Certification}

Prior to using meter(s) on Job site, furnish JAJ with current (within six months) certification of calibration. 
SECTION 01600

MATERIAL AND EQUIPMENT

PART 1.0 - EQUIPMENT - GENERAL

The wells shall be drilled by the cable tool method using drive barrel and/or hard tools. Hydraulic Jacks may be used to pull temporary casings.

\section{PART 2.0 - MATERIAL - GENERAL}

The contractor is required to furnish all materials except for those materials specifically supplied by JAJ. Materials provided by the JAJ are listed in Paragraph 1.5, Section 01100, and will be stored in the 200-East Area (see Figure 1, Section 01100). Water used during the drilling operations shall be obtained from the specified sources within the 200-East Area shown in Figure 1.

This contract requires that extreme care be exercised in handing all materials and equipment involved in the construction of the monitoring wells. Products that are permanently installed as part of the construction shall be new. The temporary casing to be backpulled shall be reused as required. Prior to reuse, the used casing must be steam cleaned according to Paragraph 3.1.3 of Section 02011 before installation.

\subsection{Construction Materials}

Materiais necessary to complete the monitoring wells in all cases shall include, but not necessarily be IImited to the items listed in this section and Section 01100. 


\section{A. Temporary Carbon Steel Casing}

All carbon steel casing shall be new $20 \mathrm{ft}$ segments. The pipe shall be Schedule 40, meeting ASTM speciffcation A53 Grade B. The individual segments shall have beveled cuts made by the Contractor before they are welded together. Casings used and pulled from wells on this project shall be used elsewhere on the project. All casings will remain the property of the JAJ.

\section{B. Drive Shoe}

New drive shoes of size to match the temporary carbon steel casings shall be furnished by JAJ. Any machining of the drive shoes necessary to reduce the outside diameters for telescoping or to limit drag during casing pull back is the responsibility of the contractor.

\subsection{Soll Test Equipment}

The Contractor shall provide the split spoon and shelby tube sampling equipment.

\subsection{Steam Cleaning Equipment}

The Contractor shall provide all equipment and appurtenances to perform the steam cleaning of equipment and material on the job site.

\subsection{Aquifer Testing Equipment}

The Contractor shall furnish all equipment and appurtenances to perform the aquifer testing described in Paragraph 3.2.3, Section 02011. 


\section{SECTION 02011}

\section{MONITORING WELLS}

PART 1.0 - GENERAL

\subsection{Work Included}

The work to be done under this contract includes the furnishing of all labor, material, transportation, tools, supplfes, plant, equipment, and appurtenances, except that material furnished by the JAJ, necessary for the complete and satisfactory construction and testing of 16 monitoring wells as described in this specification.

\subsection{Codes and Standards}

All wells shall be constructed and completed in accordance with Chapter 173-160 Washington Administrative Code, "Minimum Standards for Construction and Maintenance of Water Wells, "and the specifications contained herein. In the event of a conflict, the technical specifications contained herein shall govern.

PART 2.0 - PRODUCTS

Specified elsewhere in this specification. 


\section{PART 3.0 - EXECUTION}

\subsection{Driling}

The reliablifty of ground-water samples analyzed for hazardous chemical wastes are known to be affected by drilling methods and equipment used. All precautions must be taken to prevent contamination of the wells from any external source.

\subsubsection{Cable Tool Drilling Method}

When drilling is done by the cable tool method the following procedure shall be in effect. Drive barrel will be used where possible above the water table. Hard tools may be used thereafter. Experience in drilling similar wells on the Hanford Site has shown that the ability to pull back casing is often directly related to drilling procedures. Successful pull back has been most readily accomplished where the hole has been drilled ahead of the temporary casing and then the casing driven to the depth of the hole.

\subsubsection{Stean Cleaning}

Drill rigs and peripheral equipment (1.e., drill tools, cables, etc.) shall be steam cleaned before being used onsite. No detergents shall be used with the steam. In addition, the Contractor shall stean clean the drill rig and all equipment, including the back pulled casings, between each well to be constructed. The Contractor shall provide and maintain the steam cleaning equipment.

\subsubsection{Handling and Storage of Construction Materials}

The Contractor shall use all means necessary to protect permanent well construction materials before, during, and after installation. All materials shall be kept off the ground on pallets, stands, racks, or sawhorses. Until 
needed in the construction of a well, all materials shall be stored in their original containers.

\subsubsection{Welding}

Welding of temporary casing joints and drilling shoe/casing Joints shall be as shown in Figure 4.

\subsubsection{Tool Lubricants}

The Contractor shall use only vegetable oil (Crisco or approved equal) as lubricants for assembling tool strings. Use of all lubricants shall be kept to a minimum, and care taken to avoid accidental spillage down the borehole.

\subsubsection{Drilling Additives}

With the exception of water, no drilling additives will be allowed without written approval of JAJ. Any water used during drilling operations shall be obtained from the designated sources within the 200-East Area. Bentonite is the only recognized drilling additive which may be used (upon approval) without extensive chemical testing.

\subsubsection{Drill Cutting and Water Disposal}

Uncontaminated drill cuttings from the saturated and unsaturated zones shall be disposed of by spreading and leveling in the vicinity of the well bore. Water pumped from the wells during development shall be disposed of in the vicinity of the well bore. Water punped from the wells during aquifer testing shall be discharged a approximately of $1000 \mathrm{ft}$ away from the well bore and other wells in the vicinity, in no event shall water be disposed of on the low-level burial ground. In the event contaminated materials and/or water are encountered, disposal of those materials shall be done by JAJ. 


\subsection{Well Testing}

\subsubsection{Water LeveI Measurements}

Once the water table has been reached, water level measurements will be made in each well at the start of each shift by the site geologist with JAJ furnished equipment. Achievement of representative water-level measurements necessitates that the bottom of the temporary casing be free of plugging material at the end of each work day to allow equilibration of water level during the non-working hours.

\subsubsection{Ground-Water Samples}

Once the water table has been reached, ground-water samples will be collected from the well by the site geologist. JAJ will supply all necessary ground-water sampling equipment.

\subsubsection{Aquifer Testing}

\section{A. General}

Aquifer testing will be performed on all wells. These tests may include but are not limited to: baller, slug, step drawdown, 8 hour pumping, and 8 hour recovery tests. The contractor shall supply, install, and operate all aquifer testing equipment, which will include, but is not limited to, the following: pump(s), power source(s), flowmeter(s), valves, and 1,000 ft long discharge line. Flow meter(s) shall have certification of calibration. The submersible or turbine pump for pumping the shallow wells shall be capable of producing a yield of up to $150 \mathrm{gpm}$. The JAJ will supply equipment and personnel . necessary for data collection. 


\subsection{Formation Sampling}

As the wells are being drilled, samples of the materials penetrated witl be collected by the Contractor at $5 \mathrm{ft}$ intervals and at changes in ifthology. Sample jars will be provided by JAJ. Samples of selected confining bed materials (clays or silts) will be collected using shelby tube or split-spoon samplers. Samples will be provided by the contractor to the site geologist for analysis. 


\subsection{Borehole Construction}

\section{A. Telescoping of Temporary Casing}

The minimum nominal diameter of the borehole at the bottom of each well shall be 8 inches. Telescoping of temporary casings shall be done at no more than $100 \mathrm{ft}$ intervals.

\section{B. Well Depth}

Final depth of wells will be determined by the site geologist. Most of the single shallow wells (approximately $330 \mathrm{ft}$ deep) will be completed in the middle Ringold Formation or glaciofluvfal sands and gravels.

\section{C. overdrilling}

In the event the borehole has been overdrilled, the 8 inch casing shall be pulled back and the hole filled with sand pack to the bottom of the completion interval. If caving of the formation is anticipated, the sand pack may be placed in the temporary casing before back pulling. In any Instance, the depth of the sand pack shall be ascertained before proceeding. The completion interval will be determined by the site geologist as each well is being drilled.

\section{Alignment}

Upon completion of drilling, a straightness test shall be performed on each well. Each well must pass a $20 \mathrm{ft}$ section of 6 inch diameter pipe (furnished by the contractor) over the entire depth.

\section{E. Temporary Casing Pull Back}

As described in the well construction procedures described in 
Paragraph 3.5, the temporary casing must be removed from the well. Failure to remove the casing is cause for well abandonment.

\subsection{Well Construction}

\section{A. Setting 8 Inch Screen}

A $10 \mathrm{ft}$ section of 8 inch (telescope size) stainless steel screen shall be installed at the bottom of the well. The 8 inch casing shall then be pulled back, to expose the $10 \mathrm{ft}$ section of screen to the formation.

\section{B. Well Development/Aquifer Test}

Each well will then be developed by bailing, jetting, pumping, and/or other acceptable techniques as approved by JAJ. At a minimum, each well shall be developed until it is cleared of sand and other fine grained material, as determined by the site geologist. A test pump will then be installed and an aquifer test performed.

\section{c. Setting 4 Inch Screen, Casing, and Centralizers}

Upon completion of the aquifer test and removal of the test pump, each well will be completed by installing an estimated 10 to $30 \mathrm{ft}$ section of 4 inch (pipe size) stainless steel screen inside the 8 inch screen. The top of each 4 inch well screen shall be threaded to 4 inch diameter stainless steel casing before lowering the screen in the hole. The stainless steel casing shall extend from the top of the well screen to between $2 \mathrm{ft}$ and $3 \mathrm{ft}$ above the land surface.

A centralizer will be attached to the 4 inch casing so the bottom of the centralizer is located $20 \mathrm{ft}$ above the top of the 4 inch screen. 


\section{Sand Pack}

An artificial sand pack will then be placed between the 4 inch and 8 inch screens to the top of the 8 inch screen. The 8 inch casing shall then be back pulled a nominal $2 \mathrm{ft}$ and sand pack installed to the bottom of the 8 inch casing. In the event that caving of the hole is anticipated, the sand pack and other well completion materials may be installed between the temporary and permanent casings prior to pull back. In no instance shall more than two (2) $\mathrm{ft}$ of sand pack or well sealant materials be installed before the casing is pulled back. The pull back and fill process will then be carried out until the sand pack is installed to $5 \mathrm{ft}$ above the top of the 4 inch screen.

Placement of sand pack and grout seal shall be accomplished using a tremie pipe. Sand pack placement through the tremie pipe may require the use of water to carry the sand to the required depth. Only water from the approved sources may be used for this purpose. Where multiple telescoping temporary casings have been used, the pull back and fill technique will be used untit the bottom of each successively larger casing is reached. At that point the smaller casing will be totally removed from the borehole and the process repeated back pulling the larger casing and fllling with grout as described above.

\section{E. Bentonite Pellet Seal}

At approximately $5 \mathrm{ft}$ above the top of the 4 inch well screen, a $5 \mathrm{ft}$ thick bentonite pellet seal shall be placed.

\section{F. Volclay Benton1te-Based Grout}

After installation of the bentonite pellets, Volclay bentonite-based grout shall be installed, using the pull back and fill technique. This grout shall extend from the top of the bentonite pellet seal to $3 \mathrm{ft}$ below land surface. The grout shall be a mixture of volclay bentonite-based grout (dry $m i x$ ) and water, and shall have a mud balance weight of 9.4 lbs per gallon or B-678 
greater. In the event the contractor experiences difficulty in backpuling the casing, the use of granular bentonite may be permitted to allow greater flexibility in timing.

\section{G. Concrete Seal/Concrete Mix}

The concrete mix for the well seal and the concrete pad shall be a mixture of 2 lbs of Portland cement added to one sack of Sack crete. With addition of water, the maximum slump shall be 6 inches.

The remaining $3 \mathrm{ft}$ of annular space between the 4 inch permanent casing and the borehole shall be sealed with concrete as the temporary casing is removed completely from the borehole.

\section{H. Concrete Pad with Brass Plate}

Install a $4 \mathrm{ft} \times 4 \mathrm{ft} \times 4$ inch concrete pad around and centered on the well. The Contractor shall furnish and use formwork. Chamfer all exposed edges $1 / 2$ inch. Concrete surface to have a light broom finish and be sloped 1/4 inch per foot away from the well casing for drainage. Concrete shall be placed against compacted or undisturbed sol1. Install JAJ furnished brass plate in slab before concrete sets.

\section{Guardposts}

Place guardposts at the four corners of the concrete pad, and $4 \mathrm{ft}$ away from the well. The posts shall be 4 inch nominal diameter, schedule $40,6.5 \mathrm{ft}$ Iong meeting the requirements of ASTM A120. Posts shall be embedded in the soil 2'-6". Backfill shall be firmily compacted. Paint above ground portion of each post with one prime coat and two finish coats. Prior to painting, the steel posts shall be thoroughly wirebrushed to remove all dirt, rust, and other foreign material. 011, grease, and similar substances shall be removed with solvents. 
The yellow color for finish coats shall be as defined in ANSI 253.1, Safety Color Code for Marking Physical Hazards. Primer and paint materials shall conform to the following Federal Specifications:

$\begin{array}{ll}\text { - } & \text { Primer for metal post } \\ \text { - Finish enamel } & \text { TT-P-645 }\end{array}$

Spray paint shall not be used on the jobsite.

\section{J. Cleanup}

The Contractor shall remove construction debrys and litter from each well site. Unused JAJ furnished material shall be returned to the designated storage areas and be properly stored as it was found.

\subsection{Well Abandonment}

In the event the Contractor's well does not pass the straightness test and the contractor is unable to pull back all temporary casing from the borehole, the well shall be abandoned at the Contractor's expense.

All costs of drilling and testing of the hole shall be at the contractor's expense unless caused by circumstances beyond his control.

A well to be abandoned shall have the casing perforated. The minimum number of perforations with a Mill's Knife shall be eight cuts per round and one round per foot. The borehole shall be backfilled with Volclay bentonite grout mix (see Paragraph 3.5(F)) or other JAJ approved material. Material shall be placed with a tremie pipe.

\subsection{Drilling Log (Figure 4)}

On the form furnished, the Contractor shall keep a daily log of operations performed on each well. The $\log$ will be accurate and legible with entries made in continuous chronological order. The log shall contain the following: B-678 
Geologist, date, driller, helpers, rig number, well number, depth at beginning of shift, shift, depth at completion of shift, JAJ contract number, total casing (temporary and permanent), drill method, wet/dry sample, Ifthologic description, time drilling comments, and all other pertinent information about the well. The log shall include a list of all contract pay quantities installed during the shift. The log shall be complete, signed and dated by the driller and site geologist at the end of each shift. The original log shall be submitted to JAJ at the end of each work day. 


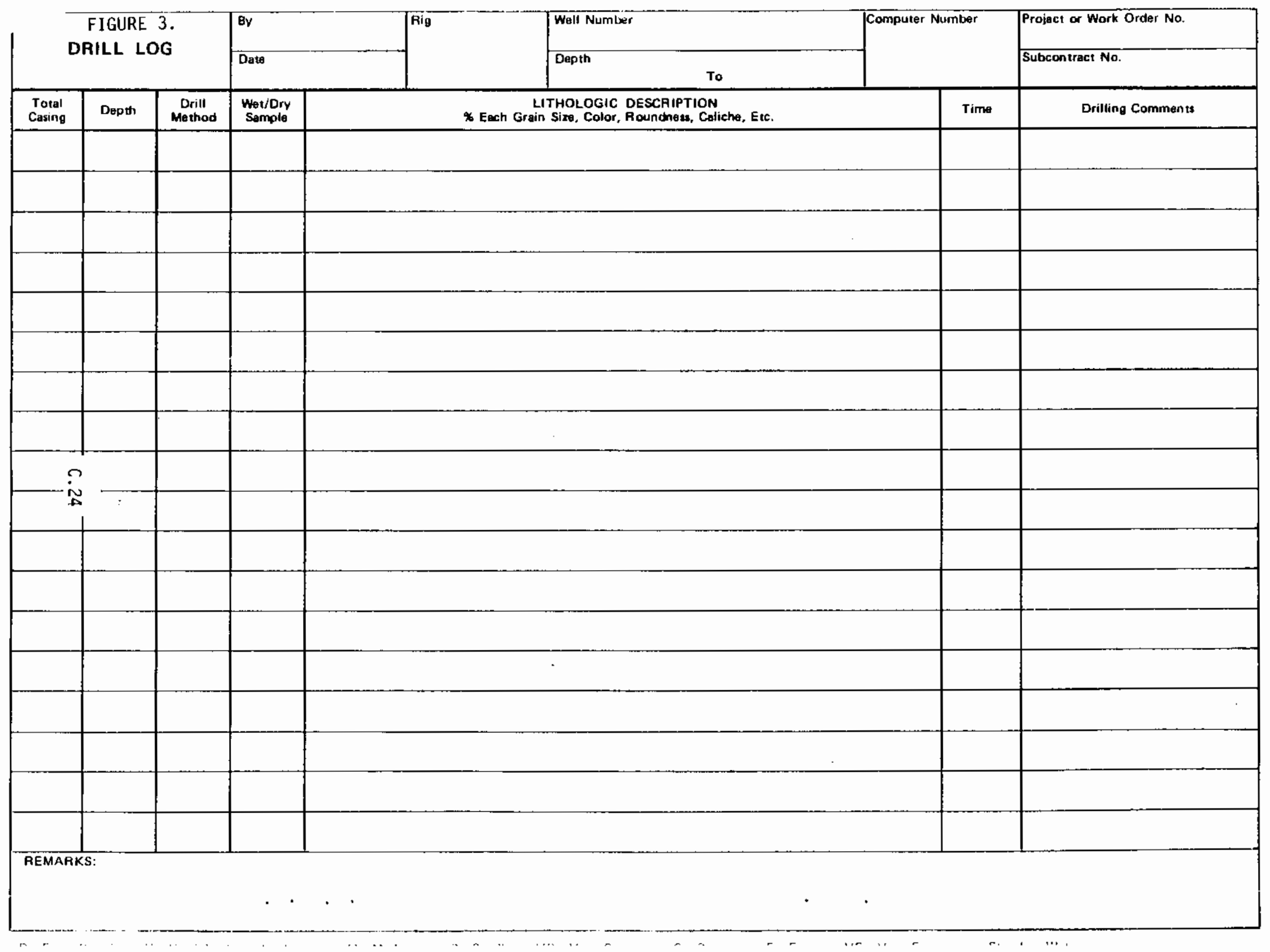




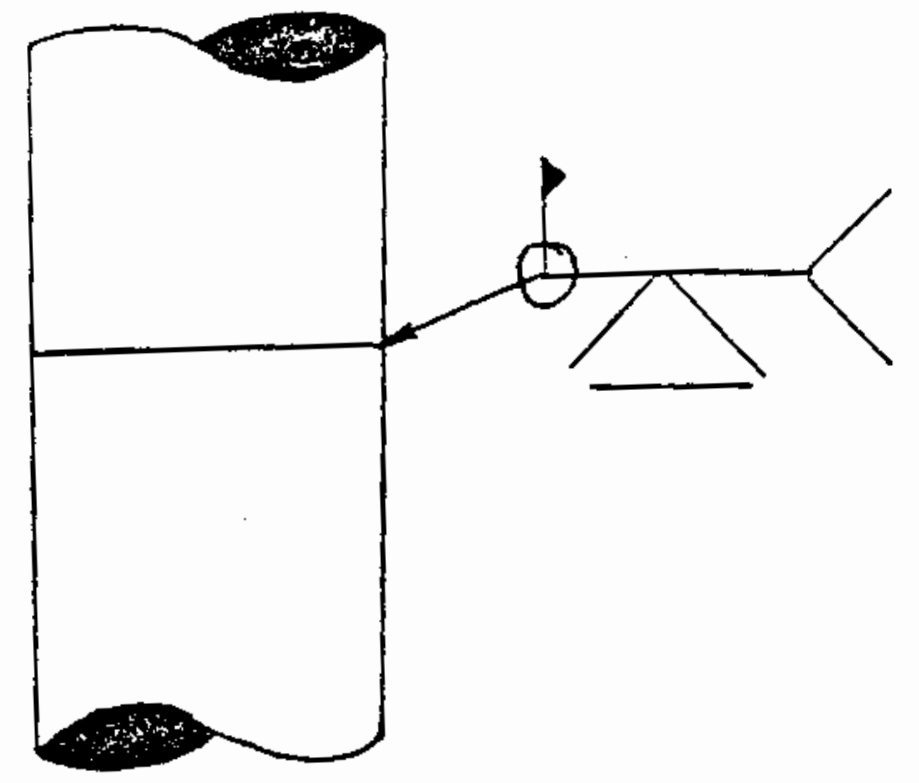

Typical Detail for Temporary Casing Joints

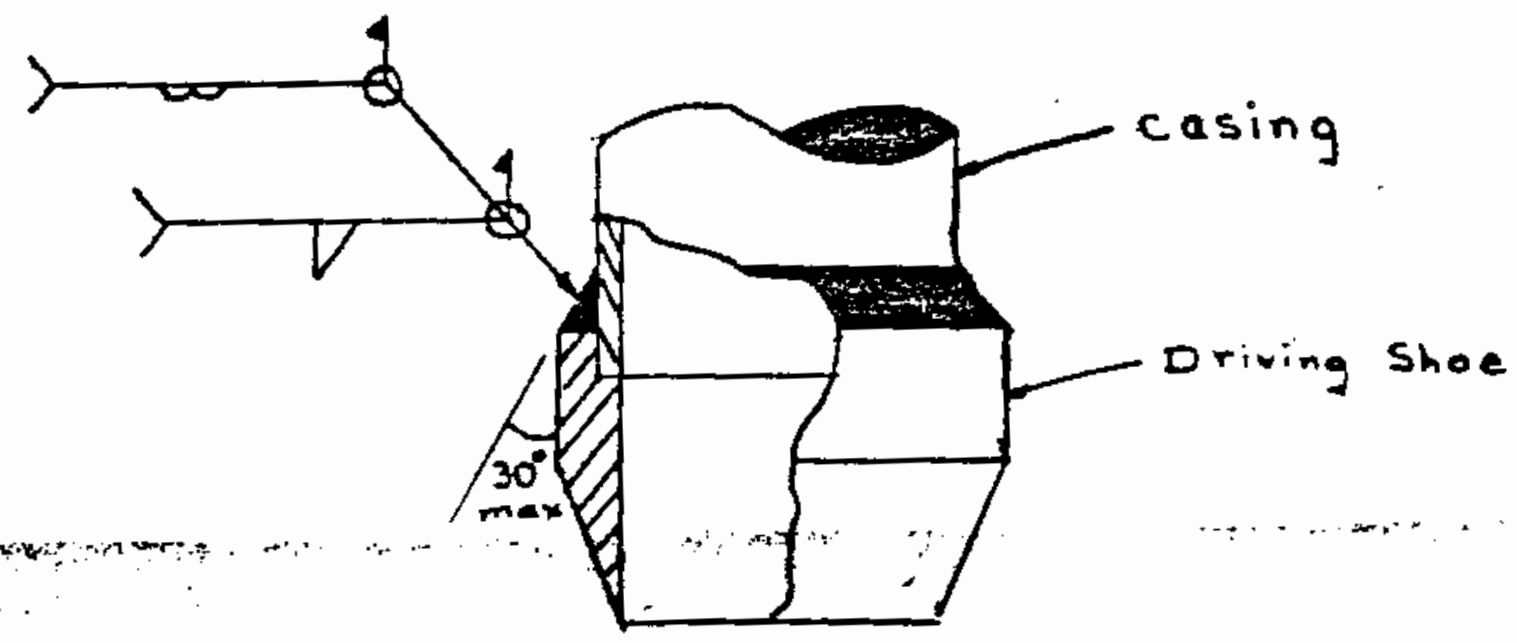

Detail at Casing -Driving Shoe Joint

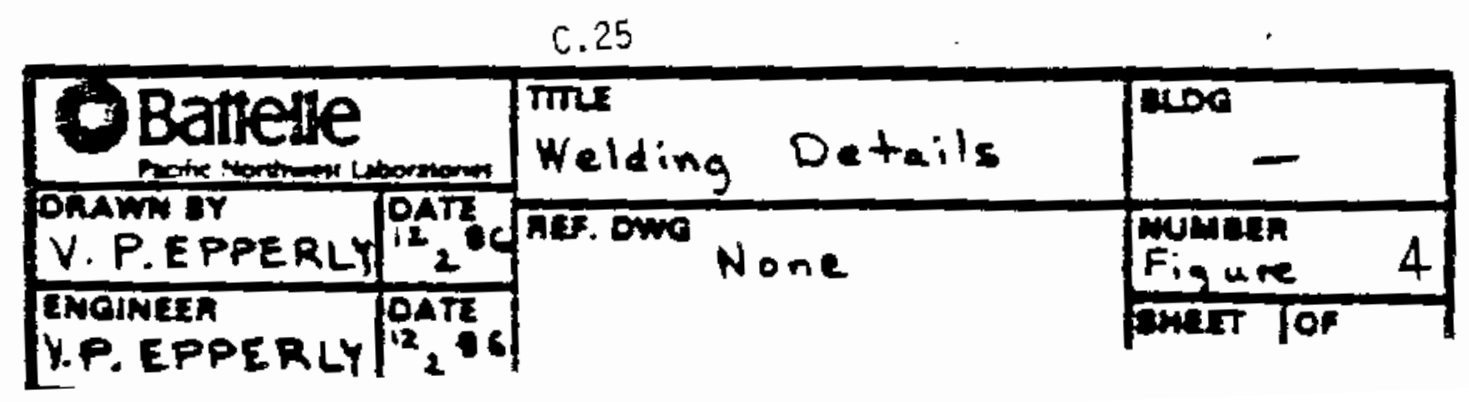




$$
\text { Specffication JAJ 1914-1 }
$$

Project No. B-677

\title{
CONSTRUCTION SPECIFICATIONS \\ GROUND-WATER MONITORING WELLS \\ HANFORD 200-WEST AREA LOW-LEVEL BURIAL GROUNDS \\ AND REIRIEVABLE STORAGE UNITS
}

\author{
Prepared by \\ U.S. Department of Energy \\ Pacific Northwest Laboratory \\ Operated by \\ Battelle Memorial Institute
}

PNL

Project Manager
Facilities Engineering

RHO

Project Engineer

Construction Engineer

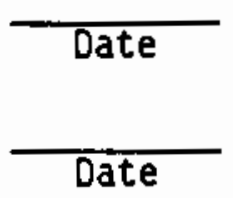

$\overline{\text { Date }}$

$B-678$

C. 26 


\section{TABLE OF CONTENTS}

Division 1 - General Requirements

Section 01100 - Summary of Work and Administrative Provisions

Section 01300 - Submittals

Section 01600 - Material and Equipment

Division 2 - Site Work

Section 02011 - Monitoring Wells 
SECTION 01100

SUMAARY OF WORK AND ADMINISTRATIVE PROVISIONS

PART 1.0 - GENERAL

\subsection{Work Included}

The work under this contract includes the furnishing of all labor, material, transportation, tools, supplies, plant, equipment, and appurtenances, unless hereinafter specifically excepted, necessary for the complete and satisfactory construction and testing of 19 monitoring wells. The nineteen wells consist of four (4) well pairs having a shallow well and a deep well, and eleven (11) individual shallow wells. The effort and materials required for this work include, but are not necessarily limited to:

A. Construction and testing of nineteen shallow monitoring wells (approximately $250 \mathrm{ft}$ deep).

B. Construction and testing of four monitoring well pairs, each consisting of one shallow well (approximately $250 \mathrm{ft}$ ) and one deep wel1 (approximately $450 \mathrm{ft}$ ).

c. Loading, hauling, and using Owner furnished material as needed from the designated storage area for construction of the monitoring wells.

D. Hauling, loading, cleaning, and storing any unused owner furnished material to the designated storage area.

E. Furnishing and using bailers, pumps, and surge blocks to develop monitoring wells.

F. Furnishing and using submersible and/or line-shaft turbine pumps for aquifer tests. 
G. All other related items needed for a complete and proper installation and testing of the monitoring wells in accordance with the intent of the specifications.

H. Pouring and finishing a concrete pad ( $4 \mathrm{ft} \times 4 \mathrm{ft} \times 4 \mathrm{in}$ ) around each completed monitoring well, placing a brass plate in the concrete pad, and installing guard posts.

\section{1 .1 Site Maps}

Figure 1 (attached) shows the approximate well locations, the designated storage areas of Owner furnished material, and locations of approved water sources.

All drilling sites are located in the 200 -West Area or inmediate vicinity within the Hanford Site in the State of Washington, approximately 30 road miles north of Richland. Each well site is clearly marked and labeled in the field with a stake palnted fluorescent orange. Access to the drilling locations within the area shown in Figure 1 is primarlly by gravel covered or unimproved dirt roads.

\subsubsection{Site Geology and Well Configuration}

The contractor should anticipate driling in unconsolidated to consolidated materials, consisting of clay, silt, sand, gravel, cobbles, and boulders. These materials were deposited in fluvial and glaciofluvial environments and may be cemented, forming hardened layers of variable thickness. Figure 2 shows the general configuration of the completed shallow and deep monitoring wells. 


\subsubsection{Other Conditions}

Low levels of radiological and chemical contamination may be encountered during drilling. JAJ will provide routine monitoring of the drill cuttings and fluids penetrated in each borehole. Radiation and organic vapor monttoring will be provided during all drilling to assure safety of all workers. In the event contamination is encountered, protective clothing will be provided to the Contractor by JAJ.

\subsection{Qualifications of Contractor}

All drillers shall be licensed well drillers in the State of Washington and have a minimum of five years cable tool drilling experience using both drive barrel and hard tool. If rotary drifling is to be used, drillers using those machines shall have equivalent rotary drilling experience.

The Contractor will supply documentation of wells he has completed for Resource Conservation and Recovery Act (RCRA) ground-water monitoring and accepted by the Washington State Department of Ecology, the Environmental Protection Agency, or other regulatory agency.

\subsection{Work Sequence}

A well that is started shall be constructed in a continuous operation.

The Contractor shall coordinate his work so the aquifer testing of paired wells can be performed as described in Paragraph 3.2.3 of Section 02011 .

\subsection{Well Site Inspections}

The site geologist will be present to perform the inspection necessary to ensure the proper installation of the monitoring wells in strict accordance with all specifications contained in this contract. 


\subsection{JAJ-Furnished Products}

A. Stainless Steel Screen (8 inch telescope size)

Stainless steel screen will be new, 8 inch telescope size, Type 304 stainless steel, $10 \mathrm{ft}$ long. The screens will be of the continuous slot, wire-wound design with flat stainless steel plates, with batler hook, factory welded to the bottom. The slot size will be 0.030 inch. The screens will have been factory cleaned and separately wrapped in protective polyethylene for shipment.

\section{B. Stainless Steel Screen (4 Inch)}

Stainless steel screen w11l be new, 4 inch nominal diameter, Type 304 stainless steel. The screens will be of the continuous slot, wire-wound design. Lengths of screen will be furnished with flat stainless steel plates, with bailer hook, factory welded to the bottom of each screened 
interval. Additional lengths of screen will be furnished with threaded end fittings. The end fittings will be double entry stub ACME flush screw threads. The screen slot size will provide a minimum open area of $11 \%$ with 0.020 inch slot openings.

Screens will have been factory cleaned and individually and separately wrapped in protective polyethylene prior to shipment. The well screen will be manufactured by Johnson Division, UOP, St. Paul, Minnesota, or an approved equal.

\section{Centralfzers}

Centraifzers will be 304 stainless steel. Centralizers will be of such a design that minimal interference with placement of well completion materiais via the tremie pipe method will be experienced.

\section{Stainless Steel Casing (4 inch)}

Stainless steel casing will be new, 4 inch nominal diameter, Type 304 stainless steel. The pipe will be Schedule 5, meeting ASTM specification A312 or A778. The individual segments of stainless steel casing will be flush coupled the same as the well screen. Ends of the casing shall be Schedule 40 to provide adequate wall thickness for threaded joints. Casing will have been steam cleaned and allowed to air dry prior to sealing and packaging at the factory. Casing will be furnished in lengths of $10 \mathrm{ft}, 5 \mathrm{ft}$, and $2 \mathrm{ft}$.

\section{E. Artificial Sand Pack}

Artificial sand pack material will consist of kiln dried quartz (silica) sand, 0.023 to 0.032 inch (U.S. sieve size 20 to 30 ) in diameter, rounded and spherical grains, packaged in sacks. 


\section{F. Bentonite Pellets}

Bentonite pellets will be composed of commercialiy available pellets, Volclay Pellets or approved equal, 0.25 inches in diameter, in buckets.

\section{G. Bentonite Grout}

Volclay bentonite-based grout (dry $m i x$ ), packaged in sacks.

H. Granular Bentonite

Granular bentonite will be composed of coarse granular bentonite crumbles, packaged in sacks.

\section{Sack Crete}

Provided in sacks.

\section{J. Portland Cement}

Provided in sacks

\section{K. Hell Cap}

Each well will have a locking, removable, stainless steel cap designed to slip over the permanent stainless steel casing and to provide adequate clearance for the dedicated sampling pump hardware.

L. Brass Survey Marker

M. Sample Jars

Glass jars as required. 
0. Hydrologic Sampling Equipment

P. Drive Shoes

Orive shoes in appropriate sizes for casing furnished.

Q. Carbon Steel Casing

ASTM A53 Grade B, Schedule 40 seamed pipe. Pipe will be initially in 20 $\mathrm{ft}$ random lengths. Diameters provided will be $16 \mathrm{in}, 14 \mathrm{in}, 12 \mathrm{in}, 10 \mathrm{in}$ and 8 in.

R. Guard Posts

Guard posts will be 4 in diameter schedule 40 pipe, $6.5 \mathrm{ft}$ long.

S. Paint 
SECTION 01300

SUBMITTALS

PART 1.0 - GENERAL

\subsection{Work Included}

This section lists submittals required of the Contractor.

\subsection{Submittals}

\subsubsection{Information to be Submitted with Bid Package}

A. Contractor Washington State Drillers License

Submit copies of licenses for Contractor and drillers.

B. Driller Method and Equipment

Submit a description of the equipment to be used and the methods to be used to construct the wells, including methodology of setting and removing temporary casing.

\section{c. Personnel Qualifications}

Furnish resumes for all supervisors, drillers, and helpers that will be on the job site. State specifically the fob experience relating to the drilling of monitoring wells that have been done and accepted by the U.S. Environmental Protection Agency, the Washington State Department of Ecology, or other regulatory agency. 


\subsubsection{Performance Submittals}

A. Construction Schedule

Submit an inftial construction schedule within 10 days of award of contract. Revise the schedule as needed to meet the contract completion date.

B. Drilling Logs

Submit the signed and completed logs as specified in Section 02011.

\section{Flow Meter Certification}

Prior to using meter(s) on job site, furnish JAJ with current (within six months) certification of calibration. 


\section{SECTION 01600 \\ MATERIAL AND EQUIPMENT}

PART 1.0 - EQUIPMENT - GENERAL

The wells shall be drilled by the cable tool method using drive barrel and/or hard tools. In the paired wells, the shallower of the two wells may be drilled using air-rotary methods using top-head drive and casing hammer. Hydraulic jacks may be used to pull temporary casings.

\section{PART 2.0 - MATERIAL - GENERAL}

The contractor is required to furnish all materials except for those materials specifically supplfed by JAJ. Materials provided by the JAJ are listed in Paragraph 1.5, Section 01100, and will be stored in the 200 Areas (see Figure 1, Section 01100). Water used during the drilling operations shall be obtained from the specified sources within the 200-West Area shown in Figure 1.

This contract requires that extreme care be exercised in handing all materials and equipment involved in the construction of the monitoring wells. Products that are permanently installed as part of the construction shall be new. The temporary casing to be backpulled shall be reused as required. Prior to reuse, the used casing must be steam cleaned according to Paragraph 3.1.3 of Section 02011 before installation. 


\subsection{Construction Materials}

Materials necessary to complete the monitoring wells in all cases shall include, but not necessarlly be limited to the items listed in this section and section 01100 .

\section{A. Temporary Carbon Steel Casing}

All carbon steel casing shall be new $20 \mathrm{ft}$ segments. The pipe shall be Schedule 40, meeting ASTM specification A53 Grade B. The individual segments shall have beveled cuts made by the Contractor before they are welded together. . Casings used and pulled from wells on this project shall be used elsewhere on the project. All casings will remain the property of the JAJ.

\section{B. Drive Shoe}

New drive shoes of size to match the temporary carbon steel casings shall be furnished by JAJ. Any machining of the drive shoes necessary to reduce the outside diameters for telescoping or to limit drag during casing pull back is the responsibility of the contractor.

\subsection{Soil Test Equipment}

The Contractor shall provide the split spoon and shelby tube sampling equipment.

\subsection{Steam Cleaning Equipment}

The Contractor shall provide all equipment and appurtenances to perform the steam cleaning of equipment and material on the job site. 


\subsection{Aquifer Testing Equipment}

The Contractor shall furnish all equipment and appurtenances to perform the aquifer testing described in Paragraph 3.2.3, Section 02011. 
SECTION 02011

MONITORING WELLS

PART 1.0 - GENERAL

\subsection{Work Included}

The work to be done under this contract includes the furnishing of all labor, material, transportation, tools, supplies, plant, equipment, and appurtenances, except that material furnished by the JAJ, necessary for the complete and satisfactory construction and testing of 19 monitoring wells as described in this specification.

\subsection{Codes and Standards}

All wells shall be constructed and completed in accordance with Chapter 173-160 Washington Administrative Code, "Minimum Standards for Construction and Maintenance of Water Wells," and the specifications contained herein. In the event of a conflict, the technical specifications contained herein shall govern.

\section{PART 2.0 - PRODUCTS}

Specified elsewhere in this specification. 


\section{PART 3.0 - EXECUTION}

\subsection{Drilling}

The rellability of ground-water samples analyzed for hazardous chemical wastes are known to be affected by drilling methods and equipment used. All precautions must be taken to prevent contamination of the wells from any external source.

\subsubsection{Cable Tool Drilling Method}

When drilling is done by the cable tool method the following procedure shall be in effect. Drive barrel will be used where possible above the water table. Hard tools may be used thereafter. Experience in drilling similar wells on the Hanford Site has shown that the ability to pull back casing is often directly related to drilling procedures. Successful pull back has been most readily accomplished where the hole has been drilled ahead of the temporary casing and then the casing driven to the depth of the hole.

\subsubsection{Afr Rotary Drflling Method}

When drilling is done by the air rotary method the following procedure and precautions shall be in effect. Tri-cone bits are the preferred method. Down-hole hammers will be permitted. However, at no time shall the down-hole hammer be used with lubricants other than water from the approved source. Extreme care shall be taken to control cuttings at the surface. Temporary casing shall be driven as the borehole is advanced. 011 traps and filters will be installed and maintained on the compressor units to eliminate $99 \%$ or more of entrained oils in air used down-hole. 


\subsubsection{Steam Cleanting}

Drill rigs and peripheral equipment (i.e., drill tools, cables, inciuding the inside of alr rotary drill string, etc.) shall be stean cleaned before being used ons1te. No detergents shall be used with the steam. In addition, the Contractor shail stean clean the drill rig and all equipment, including the back pulled casings, between each well to be constructed. The contractor shall provide and maintain the stean cleaning equipment.

\subsubsection{Handling and Storage of Construction Materials}

The Contractor shall use all means necessary to protect permanent well construction materials before, during, and after installation. All materials shall be kept off the ground on pallets, stands, racks, or sawhorses. Until needed in the construction of a well, all materials shall be stored in their original containers.

\section{1 .5 Welding}

Welding of temporary casing jolnts and drilling shoe/casing joints shall be as shown in Figure 4 .

\subsubsection{Tool Lubricants}

The Contractor shall use oniy vegetable oil (Crisco or approved equal) as lubricants for assembling tool strings. Use of all lubricants shall be kept to a mintmum, and care taken to avold accidental spillage down the borehole.

\subsubsection{Drilling Additives}

With the exception of water, no driling additives will be allowed without written approval of JAJ. Any water used during drilling operations shal1 be obtained from the designated sources within the 200-West Area. Bentonite is B-677 
the only recognized drilling additive which may be used (upon approval) without extensive chemical testing.

\subsubsection{Drill Cutting and Water Disposal}

Uncontaminated drill cuttings from the saturated and unsaturated zones shall be disposed of by spreading and leveling in the vicinity of the well bore. Water pumped from the wells during development shall be disposed of in the vicinity of the well bore. Water pumped from the wells during aquifer testing shall be discharged a approximately of $1000 \mathrm{ft}$ away from the well bore and other wells in the vicinity, in no event shall water be disposed of on the low-level burial ground. In the event contaminated materials and/or water are encountered, disposal of those materials shall be done by JAJ.

\subsection{Well Testing}

\subsubsection{Water Level Measurements}

Once the water table has been reached, water level measurements will be made in each well at the start of each shift by the site geologist with JAJ furnished equipment. Achievement of representative water-level measurements necessitates that the botton of the temporary casing be free of plugging material at the end of each work day to allow equilibration of water level during the non-working hours.

\subsubsection{Ground-Water Samples}

Once the water table has been reached, ground-water samples will be collected from the well by the site geologist. JAJ will supply all necessary ground-water sampling equipment.

\subsubsection{Aquifer Testing}




\section{A. General}

Aquifer testing will be performed on all wells. These tests may include but are not limited to: baller, slug, step drawdown, 8 hour pumping, and 8 hour recovery tests. The contractor shall supply, instali, and operate all aquifer testing equipment, which will include, but is not limited to, the following: pump(s), power source(s), flowmeter(s), valves, and 1,000 ft long discharge line. Flow meter(s) shall have certification of calibration. The submersible or turbine pump for pumping the shallow wells shall be capable of producing a yield of up to $150 \mathrm{gpm}$. The pump for pumping the deep wells shall be capable of producing up to $75 \mathrm{gpm}$. The JAJ will supply equipment and personnel necessary for data collection.

\section{B. Pair Wells}

Aquifer testing of palred wells will be accomplished using the shallow hole as the pumping well and the adjoining partially completed deep hole as the observation well. The aquifer test will be performed after the shallow well is at its full depthi the deep well has been advanced approximately 10 $\mathrm{ft}$ below the water table; and both wells have been developed by pumping.

The Contractor is responsible to coordinate the drilling and well development activities. No standby time will be paid due to coordination problems associated with the paired wells.

\subsection{Formation Sampling}

As the wells are being drilled, samples of the materials penetrated will be collected by the contractor at $5 \mathrm{ft}$ intervals and at changes in lithology. Sample Jars will be provided by JAJ. Samples of selected confining bed materials (clays or silts) will be collected using shelby tube or split-spoon samplers. Samples will be provided by the contractor to the site geologist for analysis. 


\subsection{Borehole Construction}

\section{A. Telescoping of Temporary Casing}

The minimum nominal diameter of the borehole at the bottom of each well shall be 8 inches. Telescoping of temporary casings shall be done at no more than $100 \mathrm{ft}$ intervals.

\section{B. Weil Depth}

Final depth of wells will be determined by the site geologist. Most of the single shallow weils (approximately $250 \mathrm{ft}$ deep) will be completed in the middle Ringoid Formation.

The shallow well of the paired wells (approximately $250 \mathrm{ft}$ deep) will be completed in the Ringold Formation or Glaciofiurlal sands and gravels.

The deep well of the paired wells (approximately $450 \mathrm{ft}$ deep) will be completed in the lower or basal Ringold Formation. Where the basal Ringold Formation is missing, the wells will be completed within the lower Ringold Formation at the top of the basalt bedrock.

\section{c. overdrilling}

In the event the borehole has been overdrilled, the 8 inch casing sha11 be pulled back and the hole filled with sand pack to the bottom of the completion interval. If caving of the formation is anticipated, the sand pack may be placed in the temporary casing before back pulling. In any instance, the depth of the sand pack shall be ascertained before proceeding. The completion interval will be determined by the site geologist as each well is being drilled. 


\section{Alignment}

Upon completion of drilling, a straightness test shall be performed on each well. Each well must pass a $20 \mathrm{ft}$ section of 6 inch diameter pipe (furnished by the contractor) over the entire depth.

\section{E. Temporary Casing Pull Back}

As described in the weil construction procedures described in Paragraph 3.5, the temporary casing must be removed from the well. Failure to remove the casing is cause for well abandonment.

\subsection{Well Construction}

\section{A. Setting 8 Inch Screen}

A $10 \mathrm{ft}$ section of 8 inch (telescope size) stainless steel screen shall be installed at the bottom of the well. The 8 inch casing shall then be pulled back, to expose the $10 \mathrm{ft}$ section of screen to the formation.

\section{Well Development/Aguifer Test}

Each well will then be developed by bailing, jetting, pumping, and/or other acceptable techniques as approved by JAJ. At a minimum, each well shali be developed until it is cleared of sand and other fine grained material, as determined by the site geologist. A test pump will then be installed and an aquifer test performed.

\section{c. Setting 4 Inch Screen, Casing, and Centralizers}

Upon completion of the aquifer test and removal of the test pump, each well will be completed by installing an estimated 10 to $30 \mathrm{ft}$ section of 4 inch (pipe size) stainless steel screen inside the 8 inch screen. The top of each 4 inch well screen shall be threaded to 4 inch diameter stainless steel casing B-677 
before lowering the screen in the hole. The stainless steel casing shatl extend from the top of the well screen to between $2 \mathrm{ft}$ and $3 \mathrm{ft}$ above the land surface.

A centralizer will be attached to the 4 inch casing so the bottom of the centralizer is located $20 \mathrm{ft}$ above the top of the 4 inch screen.

\section{Sand Pack}

An artificial sand pack $w+11$ then be placed between the 4 inch and 8 inch screens to the top of the 8 inch screen. The 8 inch casing shall then be back pulled a nominal $2 \mathrm{ft}$ and sand pack installed to the bottom of the 8 inch casing. In the event that caving of the hole is anticipated, the sand pack and other well completion materials may be installed between the temporary and permanent casings prior to pull back. In no instance shall more than two (2) $\mathrm{ft}$ of sand pack or well sealant materials be installed before the casing is pulled back. The pull back and fill process will then be carried out until the sand pack is installed to $5 \mathrm{ft}$ above the top of the 4 inch screen,

Placement of sand pack and grout seal shall be accomplished using a tremie pipe. Sand pack placement through the tremie pipe may require the use of water to carry the sand to the required depth. Only water from the approved sources may be used for this purpose. Where multiple telescoping temporary casings have been used, the pull back and fill technique will be used until the bottom of each successively larger casing is reached. At that point the smaller casing will be totally removed from the borehole and the process repeated back pulling the larger casing and filling with grout as described above.

\section{E. Bentonite Pellet Seal}

At approximately $5 \mathrm{ft}$ above the top of the 4 inch well screen, a $5 \mathrm{ft}$ thick bentonite pellet seal shall be placed. 


\section{F. Volclay Bentonite-Based Grout}

After installation of the bentonite pellets, Volclay bentonite-based grout shall be installed, using the pull back and fill technique. This grout shall extend from the top of the bentonite pellet seal to $3 \mathrm{ft}$ below land surface. The grout shall be a mixture of Voiclay bentonite-based grout (dry mix) and water, and shall have a mud balance weight of 9.4 lbs per gallon or greater. In the event the contractor experiences difficulty in backpulling the casing, the use of granular bentonite may be permitted to allow greater flexibilty in timing.

\section{G. Concrete Seal/Concrete M1X}

The concrete $m i x$ for the well seal and the concrete pad shall be a mixture of 2 lbs of Portland cement added to one sack of Sack crete. With addition of water, the maximum slump shail be 6 inches.

The remaining $3 \mathrm{ft}$ of annular space between the 4 inch permanent casing and the borehole shall be sealed with concrete as the temporary casing is removed completely from the borehole.

\section{H. Concrete Pad with Brass Plate}

Install a $4 \mathrm{ft} \times 4 \mathrm{ft} \times 4$ inch concrete pad around and centered on the well. The Contractor shall furnish and use formwork. Chamfer all exposed edges $1 / 2$ inch. Concrete surface to have a IIght broom finish and be sloped 1/4 inch per foot away from the well casing for drainage. Concrete shall be placed against compacted or undisturbed soll. Install JAJ furnished brass plate in slab before concrete sets.

\section{Guardposts}

Place guardposts at the four corners of the concrete pad, and $4 \mathrm{ft}$ away from the well. The posts shall be 4 inch nominal diameter, schedule $40,6.5 \mathrm{ft}$ B-677

$$
\text { C. } 48
$$


long meeting the requirements of ASTM AI20. Posts shall be embedded in the soil 2'-6". Backfill shall be firmly compacted. Paint above ground portion of each post with one prime coat and two finish coats. Prior to painting, the steel posts shall be thoroughiy wirebrushed to remove all dirt, rust, and other forelgn material. 011, grease, and similar substances shall be removed with solvents.

The yellow color for finish coats shall be as defined in ANSI 253.1, Safety Color Code for Marking Physical Hazards. Primer and paint materials shall conform to the following Federal Specifications:

- Primer for metal post

$T T-P-645$

- Fintsh enamel TT-E-489F, Class A

Spray paint shall not be used on the jobsite.

J. Cieanup

The Contractor shall remove construction debris and litter from each well site. Unused owner furnished material shall be returned to the designated storage areas and be properly stored as it was found.

\subsection{Well Abandonment}

In the event the Contractor's well does not pass the straightness test and the contractor is unable to pull back all temporary casing from the borehole, the well shall be abandoned at the Contractor's expense.

Al] costs of drilling and testing of the hole shall be at the Contractor's expense unless caused by circumstances beyond his control.

A well to be abandoned shall have the casing perforated. The minimum number of perforations with a Mill's Knife shall be eight cuts per round and one round per foot. The borehole shall be backfilled with Volclay bentonite B-677 
grout mix (see Paragraph 3.5(F)) or other JAJ approved material. Material shall be placed with a tremie pipe.

\subsection{Drflling Log (Figure 4)}

On the form furnished, the Contractor shall keep a dally log of operations performed on each well. The $\log$ will be accurate and legible with entries made in continuous chronological order. The log shall contain the following: Geologist, date, driller, helpers, rig number, well number, depth at beginning of shift, shift, depth at completion of shift, JAJ contract number, total casing (temporary and permanent), drill method, wet/dry sample, lithologic description, time drilling comments, and all other pertinent information about the well. The log shall include a list of all contract pay quantities installed during the shift. The log shall be complete, signed and dated by the driller and site geologist at the end of each shift. The original log shail be submitted to JAJ at the end of each work day. 
APPENDIX D

PROCEDURES FOR SAMPLE COLLECTION, CHAIN-OF-CUSTODY, AND FIELD MEASUREMENTS 
PROCEDURES FOR SAMPLE COLLECTION, CHAIN-OF-CUSTOOY, AND FIELO MEASUREMENTS

This appendix gives procedures used in the RCRA Compliance Monitoring Project for sample collection, chain-of-custody and field measurements. These procedures have been extracted from PNL's Environmental Monitoring Procedures manual (Earth Sciences Department, 1986). 


\subsection{HAZARDOUS MATERIALS SAMPLING}

Introduction

Environmental monitoring for a wide variety of hazardous chemicals has recently been implemented at the Hanford Site. Samples to be analyzed for these materials must, in many cases, receive special treatment. Accordingly, new procedures that are specifically designed to preserve the integrity of these samples have been developed.

The procedures to be used during collection and transportation of the samples are contained in this section. All aspects of sampling, including pump operation, borehole purging, and field measurements (water level, $\mathrm{pH}$, specific conductivity, and temperature) are described. The chain-of-custody procedures used to track and protect the samples are also inciuded. 


\subsection{WATER-LEVEL. MEASUREMENT PROCEOURE}

Introduction

Equipment

Graduated Steel Tape Method
Water-level measurements are taken each time a well is sampled, before it is purged. These measurements are taken as depth-to-water from the top of the well casing. They must be subtracted from the surveyed elevation of the casing given in Hanford Wells to obta in the elevation of the water table. The water-table elevations obtained for all wells in the sampling network during a particular sampling episode can be used to produce a contour map showing the ground-water surface at the time that the measurements were made. These contour maps can be used to help characterize the ground-water flow system and to ensure that the sampling network is adequate.

Graduated steel measuring tapes are more accurate than electrical tapes and so should be used for official measurements. However, an electrical tape can be used to determine the approximate depth to water.

The following equipment will be needed:

- steel measuring tape with attached weight

- blue carpenter's chalk

- a copy of Hanford Wells (PNL-5397)

- electrical tape

- engineer's measuring tape

- field record forms.

Chalk the 1-ft section of stee 1 tape below the zero reading point.

Find the elevation of the measuring point and the estimated water Tevel in Hanford Hells, or use an electric tape to find the approximate depth to water.

Lower the steel tape from the well's measuring point (marked with paint on the top of the casing) to the estimated water level. Note the amount of tape that is in the well by reading the tape at the measuring point. This value is referred to as the "hold point."

Remove the steel tape and check the wetted portion below the zero reading point.

NOTE: If the chalked portion is not wet, repeat the procedure, but allow more of the tape to go down the well (i.e., use a greater hold point). 
Electric Tape Method
Add the unwetted length of the chalked portion of the tape to the hold point value to obtain the depth-to-water measurement.

If the chalked portion is not wet, repeat until the water level is marked on the chalked portion of the tape.

Repeat the procedure until two steel tape measurements agree within $\pm 0.05 \mathrm{ft}$.

Record the depth-to-water measurements, time of measurements, measuring device, and the name of the person taking the measurements on the field record form.

Lower the electric tape from the measuring point into the borehole until the buzzer and the light indicate contact with the water.

Mark the electric tape at the measuring point and identify the nearest graduation on the electric tape.

If the water level is deeper than the nearest graduation marked on the tape, add the difference to the depth identified to obtain the true depth to water.

If the water level is shallower than the nearest graduation marked on the tape, subtract the difference from the depth identified to obtain the true depth to water.

Record the depth-to-water measurements, time of measurements, measuring device, and the name of the person taking the measurements on the field record form.

NOTE: This measurement should be used only as an approximate depth to water, because the electric tape is less reliable than the steel tape. 


\subsection{HAZARDOUS MATERIALS SAMPLE COLLECTION PROCEOURES}

Introduction

Equipment

Sampling

Precautions
These procedures are intended for use in collecting ground-water samples that will be analyzed for hazardous chemicals.

The following equipment may be needed in the field during sampling:

- truck-mounted air compressor and generator

- bladder-pump controller box

- bladder-pump hoses (set of 2)

- extra discharge line for biadder pump

- extra discharge line for submersible pump

- Teflon bajler

- $\mathrm{pH}$ and conductivity meter

- digital thermometer

- steel measuring tape

- blue chalk

- electrical tape

- engineer's measuring tape

- a copy of Hanford Wells (PNL-5397)

- stopwatch or watch with second hand

- bucket or jug (for measuring flow rate)

- distilled water

- ziplock bags

- ice chests with ice

- plastic gloves

- aprons

- towels

- indelible marker

- extra sample labels

- sample seals

- a copy of all relevant procedures

- sample containers with caps and liners (including extras)

- field record forms

- chain-of-custody forms

- sample-analysis request forms.

Do not smoke, eat, or handle any objects not necessary for sampling while performing sampling procedures.

Do not sample downind of any potential sources of volatile organics such as car exhausts or open fue 1 tanks. These could contaminate the sample. If any such sources are unavoidable, make a note of them on the field record forms. 
Sample Collection Using Submersible Pump
Leave caps on the sample containers until just before filling.

Avoid handling the Teflon bottle cap liners. Do not use any liner that falls out of the cap and onto the ground.

Wear gloves when taking samples and when handling containers, especially those with added preservative.

Take water-level measurements according to the water level measurement procedure.

Check to see that the hose bibb for the submersible pump is open.

CAUTION: Be sure the power switch to the $230-V$ outlets is turned off!

Plug the power cord into one of the $230-V$ outlets on the generator on the truck and into the outlet at the well head.

Start the electric generator.

Turn the power switch on to begin pumping process. Be sure not to handle energized power cords. If the pump does not work properly, as indicated by a lack of air flow out the discharge hose or by failure of the generator to "lug" down, turn the switch off immediately. After wating a few seconds, turn the switch on and off several times rapidly, finalily pausing in the ON position to determine if the pump has started to function properly.

After the water begins to flow from the outlet, pump the well for the length of time indicated in Table 13.1 (or for an adjusted pumping time, as explained in Table 13.1), and untit $\mathrm{pH}$, temperature, and specific conductivity stabilize. If the well being sampled is not listed in the table, pump for a minimum of 15 minutes and check for stabilization of the $\mathrm{pH}$, temperature, and specific conductivity.

NOTE: Some wells pump down after a period of time. If the. well pumps dry while purging, it does not generally mean that a sample cannot be collected. A sample can still be obtained by following these steps: 
1. Turn off the submersible pump when the well pumps dry.

2. Wait for the well to recharge. This should be about 15 minutes, but may take as long as 30 minutes.

3. Measure the depth to water using the electrical tape. Make sure that the water level is above the pump intake.

4. Turn the submersible pump back on. Collect the samples that are designated for collection with the submersible pump. 
Table 13.1. Calculated Pumping Times

\begin{tabular}{cc} 
Well Number & Calculated Time (min) \\
\hline (199) $H 3-1$ & 24 \\
$H 4-3$ & $5^{\star}$ \\
$H 4-4$ & $4^{\star}$ \\
$H 4-5$ & $8^{\star}$ \\
$H 4-6$ & $5^{\star}$ \\
(399) $1-1$ & 30 \\
$1-2$ & 42 \\
$1-3$ & 25 \\
$1-4$ & 34 \\
$1-5$ & $4^{\star}$ \\
$1-6$ & $6^{\star}$ \\
$1-7$ & 17 \\
$1-8$ & 29 \\
$2-1$ & 32 \\
$3-7$ & 60 \\
$3-10$ & 18 \\
$4-1$ & 35 \\
$4-7$ & 35 \\
$8-2$ & 33 \\
S30-E15A & $92^{\star}$ \\
S19-E13 & $12^{\star}$
\end{tabular}

* All wells will be pumped a minimum of 15 minutes, even if the calculated time is less.

NOTE: These pumping times are based on voiding three bore-volumes of water from the well at a pumping rate of $10 \mathrm{gpm}$. To calculate an adjusted pumping time. based on a field measurement of flow rate:

1. Divide the size of the container (in gal) by the number of seconds it took to fill. Multiply by 60 to get the new pumping rate (per minute).

2. Multiply the calcuiated time given in Table 13.1 by 10 and then divide by the new pumping rate to get the new pumping time. 
Sample Collection Using Bladder Pump
Measure the $\mathrm{pH}$, temperature, and specific conductivity of the discharged water at least three times during purging, according to the standard procedures for measuring $\mathrm{pH}$ and conductivity. The $\mathrm{pH}$ will be considered stable when two consecutive measurements agree within $0.2 \mathrm{pH}$ units. Temperature will be considered stable when two consecutive measurements agree within $0.2^{\circ} \mathrm{C}$. Conductivity will be considered stable when two consecutive measurements agree within $10 \mu$ mhos. If $\mathrm{pH}$, temperature, and conductivity do not stabilize within the calculated purging time, contact the technical supervisor before collecting samples.

Enter time, date, and your initials on all sample labels.

Record information on field record form as it becomes available. The information that must be recorded on the field record forms is described in Section 13.3 (Chain-of-Custody Procedures).

Check the labels on the sample containers to determine which ones can be filled using the submersible pump. (A blue line on the right side of the sample label indicates that the submersible pump should not be used to fill that particular container.)

Fill the appropriate sample containers as described under "General Sample Collection Procedure."

Attach a sample seal to each container and place it in a cooler or ice chest.

If the well has a dedicated bladder pump, turn on the air compressor and use the procedure described below. If the well does not have a bladder pump, use the procedures given for the Tefion bailer to collect the remaining samples.

Attach the compressor to the bladder-pump pressure inlet on the face of the controller panel, using the female portion of the coupling supplied.

Connect ejther end of the controller's red air hose to the pump supply on the right side of the control panel. Connect the other end of the controller air hose to the quick-connect nipple located in the well cap assembly.

Attach the appropriately iabeled extension line to the bladder-pump discharge line. 
Sample Collection Using Teflon BaiTer

General Sample Collection Procedure
Five to fifteen pumping cycles are required to purge the air from the bladder pump and tubing. Full water flow from the sample supply tube should then begin. After water flows from the outlet tube, run the bladder pump for at least five minutes before taking samples.

To reduce the water-flow rate during sample collection, turn the throttle control on the left side of the control panel in the counterclockwise direction. To increase the flow rate, turn the throttle control clockwise.

To optimize pumping efficiency for a specific well depth, refer to the pump manufacturer's operating instructions.

Unclasp the metal bajler from the winch $T$ ine and replace it with the Tefion bailer.

Disengage the winch clutch and slowly lower the bailer into. the water.

Engage the winch clutch when the bailer strikes the water surface.

Allow about 30 seconds for the sample tube to fill.

Turn on the electric winch and slowly raise the Tefion bailer to the surface.

Lower and rinse the bailer twice before collecting a sample.

Unscrew the cap of the sample container, being careful not to touch the lip of the bottle or the inside of the Tefion

liner. Avoid touching the mouth of the Tefion bailer.

Unclasp the Teflon bailer.

Pour the water from the bailer into the sample container slowly to prevent trapping any air bubbles. Avoid splashing or agitating the water while the sample container is being filled.

Unscrew the cap from the sample container, being careful not to touch the lip of the bottle or the inside of the Teflon liner. Also avoid touching the mouth of the discharge Tine.

Fill the sample bottie slowly by placing the outlet tube against the inner side of the sample bottle to prevent trapping any air bubbles. Avoid splashing or agitating the water while the bottle is being filled. 
NOTE: For those bottles requiring no headspace, the bottle should be filled completely so that a meniscus forms. Cap the bottle inmediately, turn it upside down, tap it a few times and check for air bubbles in the sample. If a bubble exists, discard the sample and repeat the sampling procedures until an air-free sample is obtained. There is an exception to this if the bottle to be filled contains a preservative, in which case only one attempt will be made to obtain an air-free sample.

As each container is filled, attach a sample seal to it and place it in a cooler or ice chest.

Survey the sample container with a GM instrument. If the count is greater than $200 \mathrm{c} / \mathrm{m}$, record it on the field record form and use Radiation Work Procedure 318-EE-1. Contact the EM Supervisor for instructions concerning where the sample is to be taken.

Turn off the air compressor.

Turn the power switch off and then turn the generator off. Unplug the power cord.

Complete the chain-of-custody and sample-analysis request forms .

Deliver the sample to the appropriate laboratory for analysis as soon as possible, following chain-of-custody procedures. If it cannot be delivered to the lab the same day, store the sample in a refrigerator located inside a locked building or within a secured area. The refrigerator must maintain a constant temperature of $4^{\circ} \mathrm{C}\left(39^{\circ} \mathrm{F}\right)$. Leave the

Tefion Bailer CTeaning Procedure cooler to be used when the samples are delivered.

Wash the inside and the outside of the bailer with a mild mixture of dish soap and water.

Rinse the bailer twice with tap water.

Store the bailer in a sealable plastic bag between uses. 


\subsection{CHAIN-OF-CUSTODY PROCEDURES}

Introduction

Delivery Procedures
To ensure the integrity of the samples from the time of collection through data reporting, the history of the custody of each sample will be documented according to these procedures. A sample is considered to be under a person's custody if it is in any of the following states: 1) in his physical possession; 2) in his view after he has taken possession; 3) secured by $h$ im so that no one can tamper with the sample; or 4) secured by him in an area which is restricted to authorized personnel. Anyone having custody of samples must comply with the procedures described below.

Sample Labels

Fill out and affix gummed paper labels to the sample containers prior to or at the time of sample collection. The label to be used is shown in Exhibit 13.1. The well number noted on the label identifies the well location where the sample was collected.

\section{Sample Seals}

Attach gumed paper seals to the samples immediately upon - sample collection, before the samples leave your custody. Attach the seal in such a way that the sample cannot be opened without breaking the seal.

\section{Field Record Form}

Record (in black ink) all pertinent information about each sample collected on a field record form and insert into a logbook. It will be a bound book with consecutively numbered pages. An example field record form is shown in Exhibit 13.2.

\section{Chain-of-Custody Form}

A chain-of-custody form will accompany all samples from the time they are collected until they are disposed of after analysis and reporting. A single form will be used for as many samples as possible. The form to be used is shown in Exhibit 13.3. Each person who handles the sample and signs the form will return a copy of the form to the company contact whose name appears on the top line. 
(sample number) - company code

(list of analyses)

(well number)

(bottle preparation)

SAMPLE SIZE:

LAB:

DATE/TIME:

COLLECTOR :

Exhibit 13.1. Sample Label

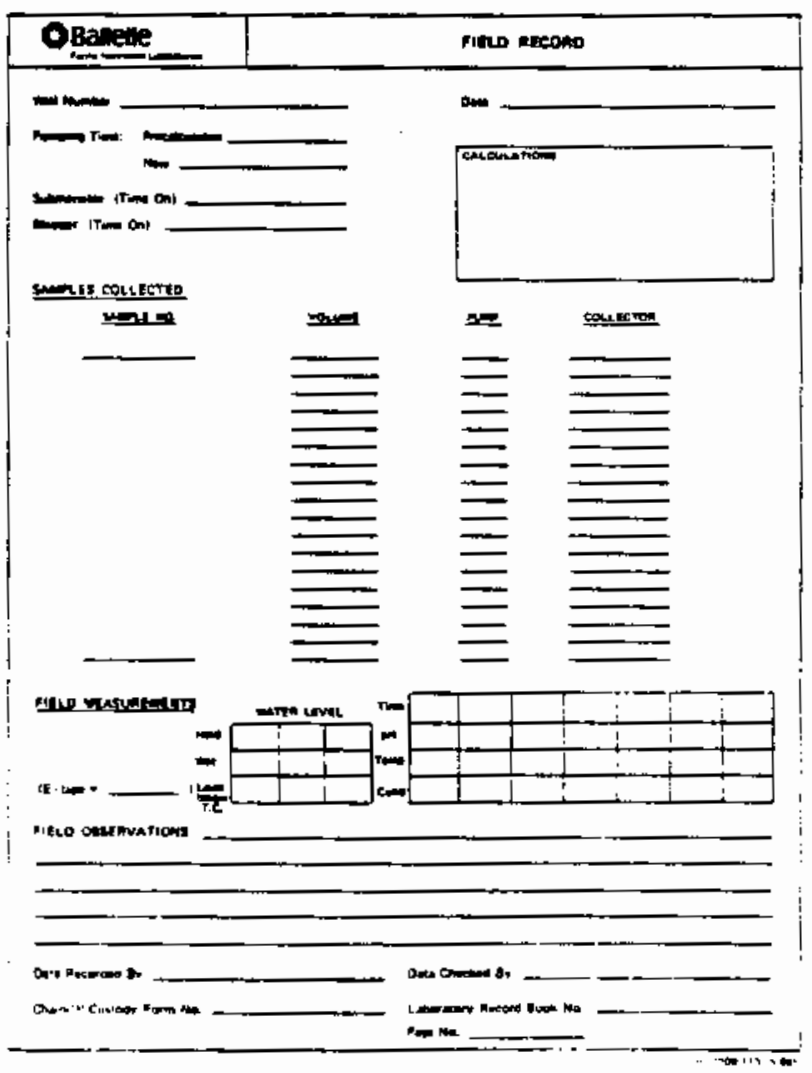

Exhibit 13.2. Example Field Record Form

0.13 


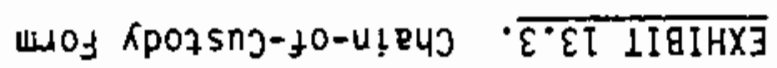

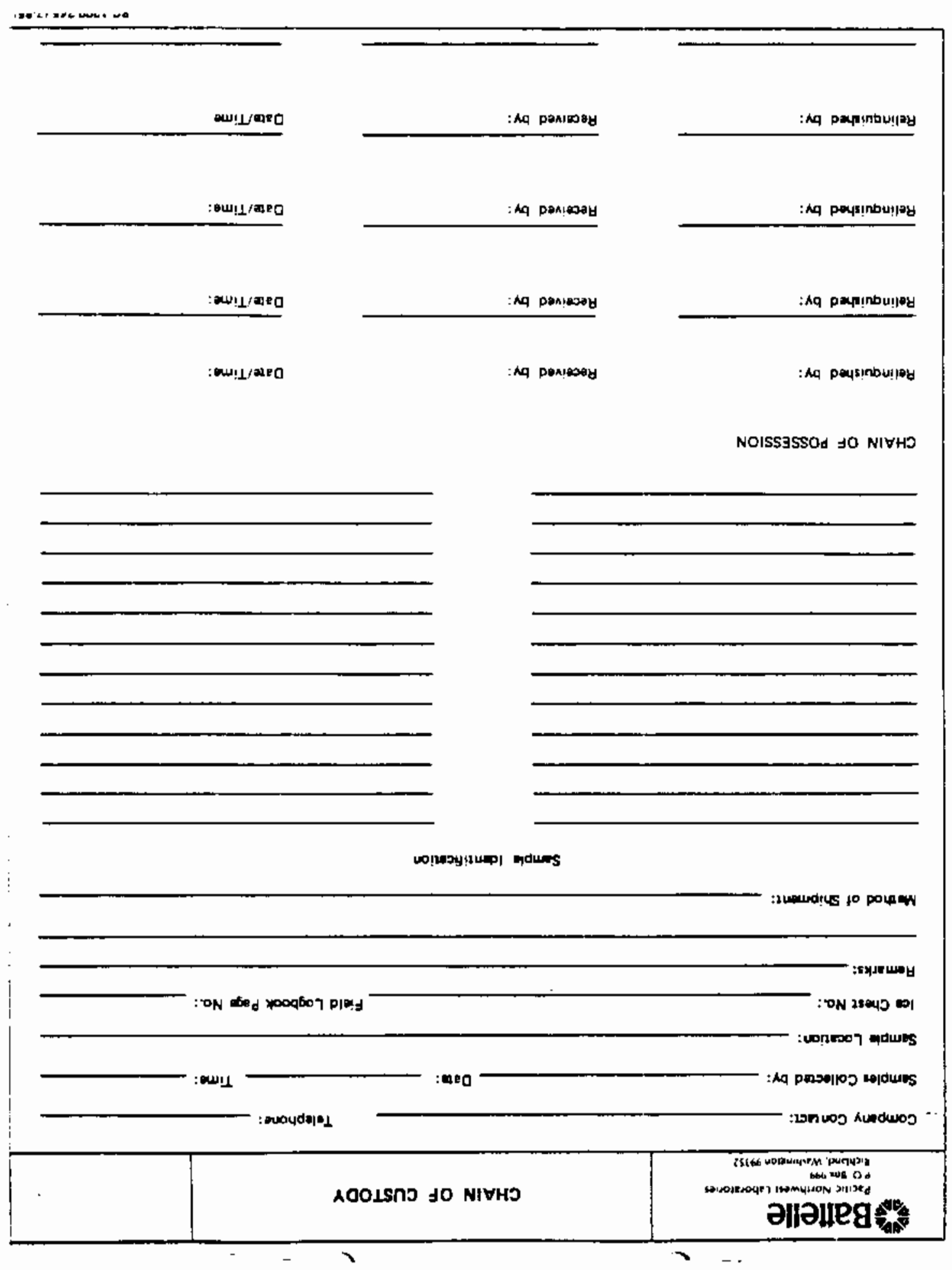


SAMPLE ANALYSIS XEQUEST

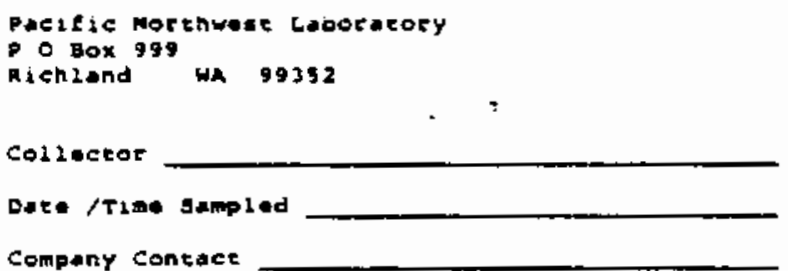

United states Teseing Company. Inc.

2800 George washingson Way

Rlehland WA 99332

Received by

TiE

Company Contace D__ Det:

T:

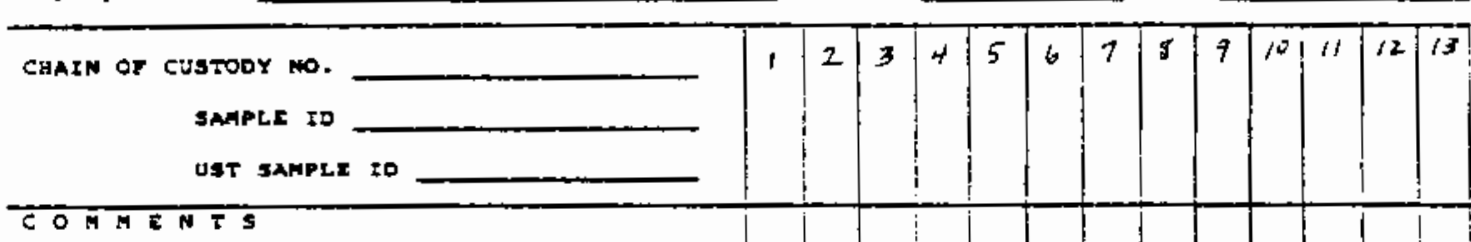

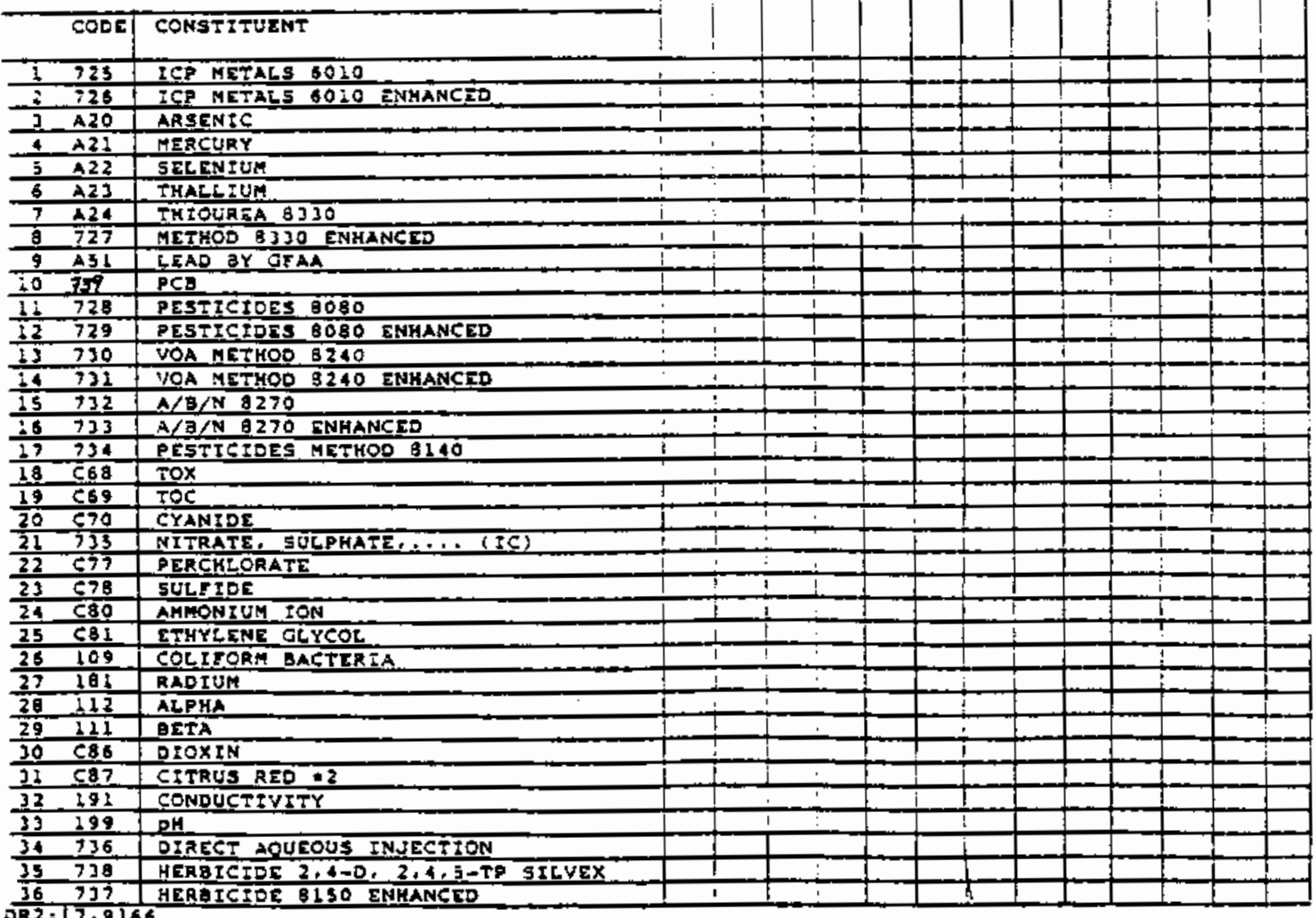

EXHIBIT 13.4. Sample-Analys is Request form

0.15 
Laboratory Acceptance Procedures

Receiving Department

Sample Custodian
Sample-Analys is Request Form

UST requires that a sample-analysis request form accompany all samples delivered to the lab. The form to be used is shown in Exhibit 13.4. The field portion of the form will be completed by the sample collector; the laboratory portion will be completed by laboratory personnel.

You will nomaliy deliver samples directly to the laboratory on the day of collection. If they cannot be delivered on the day of collection, you must store them in a refrigerator in a locked building. (No shipping of the samples will be necessary, due to the lab's proximity to the site.) ATl samples will be accompanied by a chain-of-custody form and a sample-analysis request form. Deliver samples only to authorized laboratory personnel.

The chain-of-custody does not end at the laboratory door, and therefore the laboratory must ensure the continuity of its record by following these procedures:

Remove the sample cooler from the delivery vehicle and bring it into the receiving area.

Check the sample cooler for any obvious damage.

Sign the chain-of-custody and sample-analysis request forms.

If you transfer custody of the cooler to one or more intermediates before it is delivered to the Sample Custodian, the chain-of-custody form must reflect every change of custody.

When the sample cooler is delivered to you (or your designated alternate), sign the chain-of-custody form. Then return one copy to the sender and retain the remaining copies. The sample cooler is now your responsibility (or that of your designated alternate). You must now $\log$ the samples in.

Examine the sample coolers. On the sample log-in form (Exhibit 13:5), record

- presence/absence of custody seal(s) on the samples

- condition of custody seal(s).

Open the sample coolers, examine the sample documents, and record on the sample log-in form whether chain-of-custody form(s) are present. 
DATE:

TIME :

COOLER ID

CLIENT SAMPLE ID:

UST $\rightarrow R D$ ID

NUMBER OF BOTILES IN COOLER

IS CHAIM OF CUSTODY FORM PRESENT? :

CHAIN OF CUSTOOY NUMEER

IS SAMPLE AMALYSIS REQUJEST FORM PRESEMT?

* is the custody seal on the coqler intact? :

- are the custody seals on the botrles intact? :

* do the sample labels agree with the chain of custody sheet? :

- do the sample labels agree with the sample analysis REQUEST SHEET? :

- if ansher is 'mo', please explaim belon in detail.

SAMPLES LOGSEED IN BY:

REVIENED BY SAMPLE CUSTODIAN:

Govind Rao

Exhibit 13.5. Sample Log-In Form

D.17 
Remove sample containers and record on sample log-in form:

- condition of samples (intact, broken, leaking, etc.)

- presence/absence of sample labels and sample seals

- any discrepancy with chain-of-custody form(s).

If discrepancies are found, contact the sender for clarification.

Once all samples have been properly logged in, send a copy of the sample log-in form to the company contact named on the chain-of-custody form.

Use an internal numbering system for identification of all samples.

Assign internal numbers to the samples and record the numbers on the sample log-in form alongside the corresponding sample number assigned by the collector.

Place the properly labeled sample containers in the secure storage area. 


\subsection{TEMPERATURE MEASUREMENT PROCEDURE}

Introduction

Equipment

Temperature

Mea surement

procedure
Temperature measurements are taken during and after purging of the well, just prior to sample collection. Measurements taken during purging are used to help ensure that the well bore has been sufficiently evacuated, as indicated by stabilization of the temperature. (The $\mathrm{pH}$ and conductivity are measured at the same time for the same reason.) The temperature is considered stable when two consecutive measurements agree within $0.2^{\circ} \mathrm{C}$. The final temperature measurement is taken just prior to sampling and is recorded as an analytical value for the sample. The digital themometers are regularly checked against a standard thermometer for accuracy.

The following equipment will be needed:

- digital themometer

- field record forms.

Turn on the digital thermometer. Make sure that the switch is positioned so that the measurenents will be in degrees centigrade.

Place the probe into the stream of water being discharged from the pump.

The temperature is indicated by a flashing display, which will normally fluctuate for a few seconds. Wait until fluctuation ceases (i.e., until the same temperature is indicated on three consecutive flashes), and then record the temperature on the field record form. 


\subsection{CONDUCTIVITY CALIBRATION AND MEASUREMENT PROCEDURES}

Introduction

Equipment

Conductivity Calibration Procedure
Conductivity measurements are taken during and after purging of the well, just prior to sample collection. Measurements taken during purging are used to help ensure that the well bore has been sufficiently evacuated, as indicated by stabilization of the conductivity. (The $\mathrm{pH}$ and temperature are measured at the same time for the same reason.) Conductivity is considered stable when two consecutive measurements agree within 10 umhos. The final conductivity measurement is taken just prior to sampling and is recorded as an analytical value for the sample. The conductivity meter should be calibrated once a day, before it is taken to the field to begin sampling.

The following equipment witl be needed:

- conductivity meter

- distilled or deionized water

- small screwdriver

- standard solution

- field record forms.

\section{Internal Standard}

Empty the sample cup on the meter. Rinse it out with distilled or deionized water. Ory the cup thoroughly.

Turn the range switch to TEST.

Press the OPERATE button.

Use the small screwdriver to adjust the CALI8RATE until the meter or display reads 8 .

NOTE: This is to be done as a rough calibration or battery check.

Standard Solution

Empty the sample cup. Rinse it out with distilled or deionized water.

Fill the cup with standard solution.

Turn the MODE switch to conductivity. 
Turn the RANGE selector switch to the correct range for the standard solution.

Press the OPERATE button.

Use the small screwdriver to adjust the CALIBRATE until the meter or display reads the solution value.

NOTE: Do not return the conductivity standard solution to the container. Always discard it.

Conductivity

Measurement

Procedure
Check that the conductivity meter is properly calibrated by using the internal standard.

Remove the cap from the sample cup.

Rinse the cup with the water to be tested and dump it several times. Then fill the cup with the sample.

Turn the conductivity RANGE switch to the correct range.

Range in umhos

$$
\begin{array}{ll}
\times 1 . & 0=10 \\
\times 10 . & 0=100 \\
\times 100 . & 0=1,000 \\
\times 1,000 . & 0=10,000
\end{array}
$$

Turn the MOOE switch to CONDUCTIVITY.

Press the OPERATE button on the side of the meter.

Read the conductivity on the digital display to the nearest umho and record on field record form. Multiply the meter reading times the scale factor to obtain the correct placement of the decimal point.

After taking the reading, dump the sample and refill the cup with distilled water.

Replace the cap. 


\subsection{PH CALIBRATION AND MEASUREMENT PROCEDURE}

Introduction

Equipment

pH Calibration Procedure
Measurements of the $\mathrm{pH}$ are taken during and after purging of the well, just prior to sample collection. Measurements taken during purging are used to help ensure that the well bore has been sufficiently evacuated, as indicated by stabilization of the $\mathrm{pH}$. (Conductivity and temperature are measured at the same time for the same reason.) The $\mathrm{pH}$ is considered stable when two consecutive measurements agree within $0.2 \mathrm{pH}$ units. The final $\mathrm{pH}$ measurement is taken just prior to sampling and is recorded as an analytical value for the sample. The $\mathrm{pH}$ instrument should be calibrated once a day, before it is taken to the field for sampling.

The following equipment will be needed:

- $\mathrm{pH}$ meter

- distilled or deionized water

- smalt screwdriver

- buffer solutions

- field record forms.

Wash the meter's sample cup with distilled water.

Fill the cup with 4.0 buffer solution.

Turn the MOOE switch to $\mathrm{pH}$.

Press the OPERATE button. Use the small screwdriver to adjust the ZERO to make the display read $4.00 \mathrm{pH}$ on the upper meter scale or on the digital display.

Discard the buffer solution. Wash the cup twice with distilled or deionized water.

Fill the cup with 10.00 buffer solution.

Adjust the SLOPE to make the display read $10.00 \mathrm{pH}$.

Rinse the cup again and refill it with $4.0 \mathrm{pH}$ buffer solution. Recheck the $4.0 \mathrm{pH}$ value and adjust the ZERO if necessary.

Single Buffer Calibration

After the SLOPE is calibrated the first time each day, it may be left alone for subsequent calibration. Recheck the slope as desired. 
$\mathrm{pH}$ Measurement Procedure
Calibrate with a buffer solution that is close to the range of interest. If the process $\mathrm{pH}$ is from 6.0 to 9.0 , use a 7.0 buffer solution for single-point calibration.

With the buffer solution in the cup, recalibrate only the STD to make the display read the desired value.

NOTE: Do not return buffer solutions to their containers. Always discard them.

Ensure that the $\mathrm{pH}$ instrument is properly calibrated.

Remove the cap from the sample cup.

Rinse the cup with the water to be tested several times. Then fill the cup with the sample.

Turn the MODE selector switch to $\mathrm{pH}$.

Press the OPERATE button on the side of the meter.

Read the $\mathrm{pH}$ on the upper meter scale or on the digital display to the nearest tenth of a unit. Record the value on the field record form.

Dump the sample and refill the cup with distilled water. Replace the cap. 

APPENDIX E

QUALITY ASSURANCE PLAN 


\section{QUALITY ASSURANCE (QA) PLAN}

This appendix presents the text of the QA Plan used for the RCRA Compliance Ground-Water Monitoring Project. The plan is used to identify specific elements of PNL's QA Program that are applicable to the project.

The QA Plan includes information on: project organization, the QA Program; design control and method review; procurement; instructions, procedures, and drawings; document control; identification and control of items; performance of inspections and tests; control of measuring and test equipment; status of inspection, test, and operating condition; nonconformance and corrective actions; and $Q A$ records and audits. 
OA PLAN

Project

Service Activity

Issue Dat* July 31,1986

\section{OA PLAN}

저 1830
$\square \quad 1831$

Page 1 of

\section{Project/Service Activity: Hazardous Materials Monitoring Project/RCRA Compliance Ground-Water Monitoring Project}

Sponsor: DOE, Hestinghouse Hanford Company, UiC Muclear Industries

Authorized By (DOC. No.): Project Number 11329, 11249, 11665

QA Requirement Specification:

(Specity) DOE-RL Order 5700.1A, Quality Assurance, as interpreted by PNL-14A-65 with additions and further clarifications to more fully meet sponsor requirements.

Geophysical lonoing shall be conducted in accordance with OA Plan ED-54.

The Sections or selected paragraphs of PNL-MA-65 (as identified by section of paragraph number) designated in this QA Plan are applicable to this Project/ Service Activity. Additional information is also provided when useful to provide clarification of the selected requirement.

\section{Approvals:}

\begin{tabular}{|c|c|}
\hline $\begin{array}{r}\text { DATE APPAOVED } \\
7-24-86\end{array}$ & 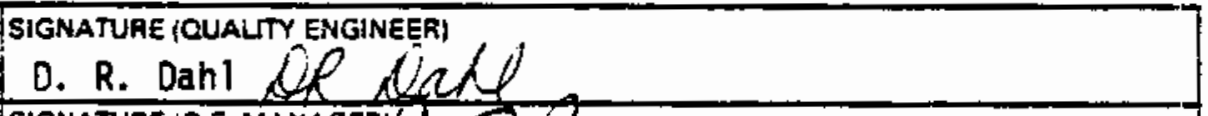 \\
\hline $\begin{array}{r}\text { PATE APPROVED } \\
2 / 257\end{array}$ & 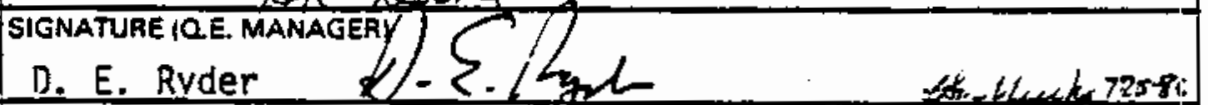 \\
\hline $\begin{array}{r}7 \text { DATE APPAOVEO } \\
7-34-84\end{array}$ & 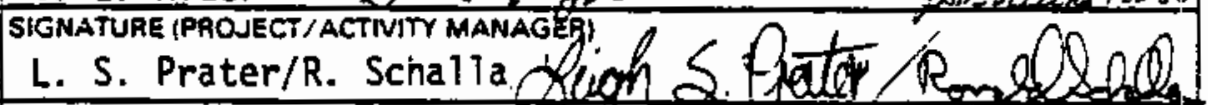 \\
\hline $\begin{array}{l}7 / 23 / 86 \\
\end{array}$ & 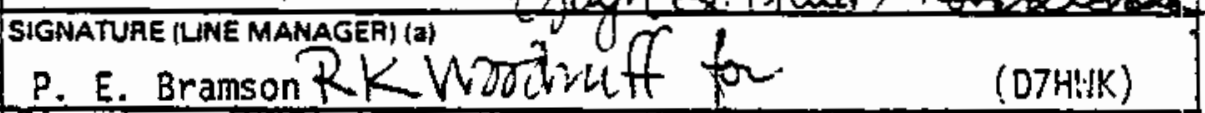 \\
\hline Date Approyed & 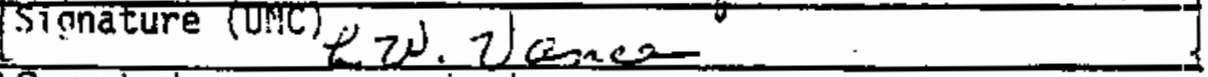 \\
\hline
\end{tabular}

Distribution: (Project QA Files, OAD, and others as appropriate)

See Oistribution, page 19

(a) Department or Section Manager as desgnated ty Deoantment Policy or the Project Plisn Document. 
QAP No. ED-41 Rev. 1

Page 2 of 19

Project: Hazardous Materials Monitoring Project/RCRA Compliance

Ground-Water Monitoring Project

1.1 Organization

1.1.1 QAO Organization

1.1.2 QAO Responsibilities

QA PLAN INDEX

2.1 QA Program

2.1.1 Applicability

2.1.2 QA Plans

2.1.3 Personnel Quatifications and Training

2.1.4 QA Program Reviem

2.2 QA Planning

2.2.1 Project QA Plan

2.2.2 Activity QA Plan

2.2.3 Revision

2.2.4 Close-Out

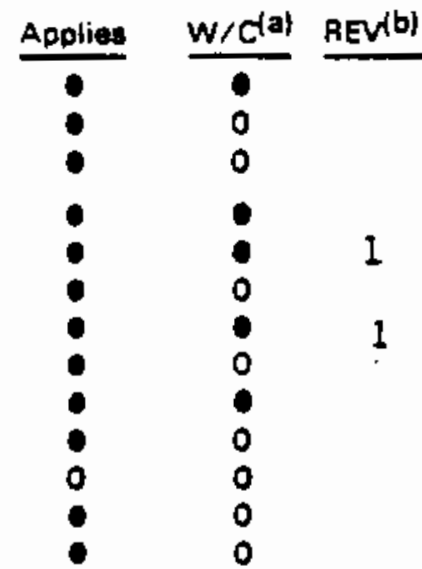

2.3 Job Quality Plan-applies to work performed by Facilities

Engineering Section and Major Projects and Planning

Organizations

2.3.1 Requiremens

2.3.2 Preparation and Approval

2.3.3 Revisions

2.3.4 Records

3.1 Design Control and Method Review

3.1.1 Design Planning

3.1.2 Project Approach and Method

3.1.3 Design and Engineering Control

3.1.3.1 Design Document Control

3.1.3.1(3) Non-Otficial Engineering Orawings

3.1.3.2 Design Criteria

3.1.3.3 Oesign Contiguration Contro!

3.1.3.4 Engineering Hold Points

3.9.3.5 Modifications

3.1.4 Calculation (Data) verification

3.1.5 Interface Controls

3.1.6 Design Review and Verificarion

3.1.6.1 Design Data on OED

3.1.6.2 Engineering Work in Support of Design

3.1.6.3 Formal Design Review

3.1.6.4 Development Testing

\subsubsection{Revisions}

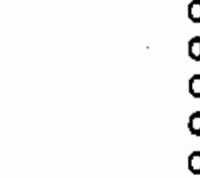

4.1 Procurement-Applies if a purchase requisition is processed (procurement or subcontract)

4.1.1 Procutement/Subcontract Document

Preparation and Approval

4.1.2 Source Inspection Activities

4.1.3 Supplier/Subcomractor Selection

4.1.4 Procurement Document Close-Out

5.1 Instructions, Procedures, and Drawings

5.1.? Ident. \& Content

5.1.2 Transmit of QA Req.

5.1.3 Compliance 
QAP No. ED-4] Rev.

Page 3 of

Project: Hazardous Materials Monitoring Project/RCRA Compliance Ground-Water Monitoring Project

\section{QA PLAN INDEX (cont'd)}

6.1 Oocument Control

6.1.1 Control of Select Documents

6.1.2 Revisions

7.1 Identitication and Control of Items

7.1.1 Identification and Control

7.1.2 Traceability

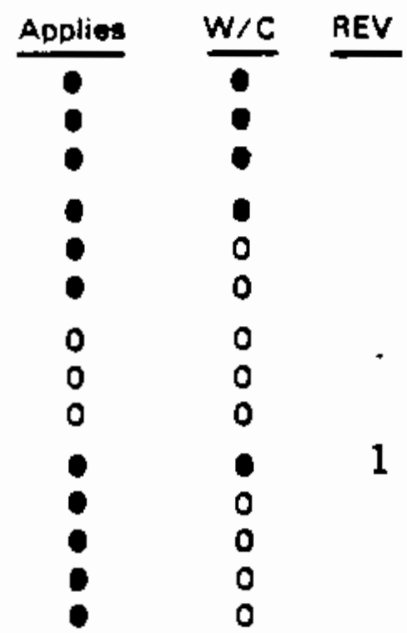

10.1 Control of Mesuring and Test Equipment

10.1.1 Basic Responsiblities

10.1.2 Pertormanca Checks

10.1.3 Calibration of M\&TE

10.1.4 Calibration Discrepancy

10.1.5 New Equipment

10.1.B Records

11.1 Handling, Storage and Shipoing

11.1.1 General Guidance

11.1.2 Speciai Instructions

12.1 Status of Inspection, Test \& Operating Condition

12.1.i Status Indication Authorities

12.1.2 Status Indication Requirements

13.1 Nonconformance \& Corrective Action

\$3.1.1 Occurrences

13.i.2 Control of Noncontorming Item

13.1.3 Corrective Action

14.1 OA Hecords

14.1.1 General Guidance

14.1.2 OA Record Requirement

14.1.3 Ĺaboratory Necord Books

15.1 Audits - Applias when e project or activity is selected as part of the base for a QA audie.

Additions

1 See Parts $1,3,6$ and 10. of this $\mathrm{AA}$ Plan 
QA PLAN ED-41, REV 1

Projects: Hazardous Haterial Monitoring Project/RCRA

Page 4 of 19

Compltance Ground-Water Monitoring Project

\section{ORGANIZATION}

1.1. The relationship of the Quality Assurance Department (QAD) to other Battelle components is described in Section 1.1 of PNL-MA-65. PNL-MA-65 identifies the responsibilities of the QAD Manager, Manager of Quallty Engineering, Quality Engineer, Lead Quality Assurance Aud1tor, and the Manager of Quality Control.

In addition:

1. The organizational structure of the HMMP and the RCRA Complfance Ground-water Monitoring project is shown in Attachment A. As shown in the diagram, both profects fall under the supervision of the Manager for Hanford Environmental Programs. The relationship between the projects and the QAD is aiso shown. Analytical laboratories include the primary testing laboratory, (currently U.S. Testing) and various other laboratories used to provide quality control checks. The QC laboratories currently include facflities of PNL, HEHF and Westinghouse Hanford Company, and may include in the future an independent offsite laboratory.

2. The PNL Project Manager shall act as interface anong profect sponsors (UNC Nuclear Industries, Westinghouse Hanford Company, and DOE-RL) and PNL regarding technical matters. The PNL Manager for Hanford Environmental and Occupational Health Programs shall act as interface for formal communications and matters regarding commitments. Status reports will be provided on a perlodic basis according to agreenents between PNL and the sponsors.

3. The Project Manager is responsible for implementing this QA PIan.

4. The responsibility of the Profect Quality Control Task Leader is to coordinate quality control samples, screen results of QC sample analysis, and maintain records concerning laboratory performance.

\section{QA PROGRAM}

2.1. Thts QA Plan applies to the monitoring, sampling, chemical analyses, evaluation, and modeling activities for the HMMP and RCRA Compliance projects at the Hanford Site.

2.1.1. This document is intended to apply to work being conducted by PNL under two projects: the Hazardous Materials Menftoring Profect (HMMP) and the RCRA Compliance Ground-Water Monitoring Project. Unless otherwise stated, all parts of this plan shall apply to both projects. 
QA PLAN ED-41, REV 1

Projects: Hazardous Material Monitoring Project/RCRA

Page 5 of 19

Compliance Ground-Water Monitoring Project

The HMMP, which is supported by the Department of Energy, involves monitoring for hazardous chemicals throughout the Hanford Site. The RCRA Compliance Project, supported by Westinghouse Hanford Company, and UNC Nuclear Industries involves ground-water monitoring for hazardous chemicais at the 300 Area Process Trenches and the 183-H Solar Evaporation Basins.

2.1.3. The Project Manager shall provide for the training of project personnel on the contents of this QA Plan and supporting procedures as necessary. This training shall be planned, performed, and documented as per PNL Administrative Procedure PAP-201, Rev. 1, which includes the following requirements:

a. A resume of each contributor to the projects shall be in the project files.

b. The Project Manager shall define training needs and methods.

c. Training assignment, schedule, plan, and attendance shall be documented.

d. Training records shall be retained by the Management Systems Department, Procedures and Training Coordination Section.

2.2 Reviston (2.2.3). The Project Manager shall notify the Quality Engineer of changes in project scope so that a revision to this QA Plan can be prepared and issued as needed.

3. DESIGN CONTROL AND METHOD REVIEW

3.1.2 Project approach and method of investigation for HMMP is described in the Project Plan for Hazardous Materials Monit toring Project for FY 1986, dated 10-01-85. The approach and method for the RCRA Compliance Project is documented in Hazardous Waste Ground-Water Monftoring Plan (July 1985). Project plans and changes in scope shall be discussed with or reviewed by the project sponsors. Such changes shall be documented in the project files. The project plan shall be approved by the Project Manager and Section Manager.

(a) New compl fance plans for each area are scheduled to be issued by August 1986. 
QA PLAN ED-41, REV 1

Projects: Hazardous Material Monitoring Project/RCRA

Page 6 of 19

Complfance Ground-Water Monitoring Project

In addition:

1. Data Base Development

A computer data base management system shall be used to store and retrieve fleld and laboratory data. Procedures for processing data into the RCRA data base shall be documented in the Hanford GroundWater Data Base Management GuIde and User's Manual. Before this manual is published, the procedures shall be controlled in accordance with Section 6.1. The Data-Handling Task Leader shail assure that the data base user's manual is current.

Computer software used to generate project data bases (i.e., software used to transfer data to the Hanford ground-water data base) has been verified. Changes to computer software shall be verified and documented.

2. Fieid Records

Radiation Protection Technologists (RPTs) shall fill out completely sign and date all required sampling records (e.g., forms and field logbook), noting any conditions that could affect interpretation of results.

Information in the field logbook shall be reviewed, initialed and dated, including any changes by the Environmental Monitoring Supervisor or the Sample Collection Task Leader.

Changes to the field logbook or to other sample collection records (e.g., Chain-of-Custody forms) will be inttialled by the person making the change.

3. Well Network Modification: Field Design Changes

Field design changes of drilling configuration/specifications shall be at the discretion of the PNL geologist and shall be controlled in accordance with Procedure P-4, Change Control. Al1 field changes and concurrence cominunications shall be documented in the PNL geologists's field notebook and kept as a permanent project record. Any design changes shall be reflected in the as-built drawings.

4. Data Base Records Verification and Security

Data from the primary analytical laboratory shall be transferred to the data base using procedures documented in the Hanford Ground-water Data Base Management Guide and User's Manual. 
- Data on computer tapes, disks, and other memory devices shall be labeled with project name, title, and directory listing.

- Master copies of computer data on tapes, disks, and other memory devices shall be stored in a secure manner that will protect them from tampering and/or damage.

- Field data shall be entered into the data base by an assignee of the Data-Handling Task Leader and independently checked for accuracy and completeness and initialed by another assignee. Desfgnation of assignees shall be documented.

- The Data-Handling Task Leader shall assure the security of the data by 1 imiting access to the system as necessary. Individuals working with the data base shall change passwords at least annually.

- The Data Evaluation Task Leader shall review the data listing from the primary laboratory concurrently with transfer of data into the data base. Any suspect data will be checked with the primary laboratory and questions resolved and documented in project records.

- All data rejected by the data base shall be listed in the printout sent to the Data Evaluation Task Leader, whose responsibility it shall be to review the Ifst and resolve with the primary laboratory questions concerning the data. Resolution of rejected data shall be documented in project files.

5. Data Base Contents and Use

- Each computer run reported or used for reporting information in project reports shall have a copy of the output stored as a project record. The record shall include date, data source, program 11sting, and software identification.

- Data and detection limtts shall be reported in the data base. The magnitude of the uncertainty (bias) in each type of analysis may be estimated by the analysis of blanks and standard samples.

- The magnitude of the prectsion of each type of analysis shall be estimated by the analysis of replicates.

- The analysis of data shall be documented and traceable from the primary source to reported results, including all assumptions, interpretation, and calculations.

- Data from interlab comparisons should be included in the data base, and noted as such. 
QA PLAN ED-41, REV 1

Projects: Hazardous Material Monitoring Project/RCRA

Page 8 of 19

Compliance Ground-Water Monf toring Project

- Colmuterized data files shall contain pertinent field and lab notations that may affect the interpretation of the results.

- Data that are suspect (out of range as determined using control charts or other checks and statistical analysis) shall be flagged as such in order to caution users of such data. Suspect data w11) be brought to the attention of the laboratory by the Data Evaluation Task Leader for possible corrective action. Resolution of suspect data shall be documented in project records and traceable to the revfewer, data base, and date.

6. System Maintained Software and Support Software

System maintained software is software that is installed and maintained at the computer system level rather than at the user level (e.g., comoercial software such as LOTUS 1-2-3, RS/1, or DISSPLA).

Support software is 1) Software that may be easily and exactiy verified, and that performs a simple function such as, change in data format or plotting of data, or 2) A stream of comands or sequence of streams of comands executed to utilize system maintained software (the system maintalned software generates reportable results).

When an applifcation of such software is to be reported to a sponsor, the following control of application runs is required.

- Code documentation shall be located in files of (or avallable to) the user. A description of the configuration of hardware shall be included as a project record. Support and system-maintained software shail be identifled by version number and date.

- Record of application runs, program and resuits, including a listing of the application (referenced to the application program) shall be maintafned in project files and identify date, program, user, data and results document.

The user, or his designee, shall review, initial and date application runs to confirm that results are reasonable. 
QA PLAN ED-41, REY 1

Projects: Hazardous Material Monitoring Project/RCRA

Page 9 of 19

Compliance Ground-Water Monitoring Project

7. The Coupled Fluid, Energy, and Solute Transport (CFEST) Software Development/Modifications

The acquited Coupled Fluid, Energy, and Solute Transport (CFEST) code, developed under another PNL program for license-related application, will be calibrated to model ground-water flow and tritium transport in the unconfined aquifer at Hanford. The code is to be enhanced to simulate the movement of hazardous chemical constituents in ground water.

Computer software design, development and appilcation shall be documented by the Model Enhancement Task Leader. This documentation, as a minimum, shall address the following:

- Software design/development

- Testing and verification of software and modifications

- Configuration control of software versions

- Storage of software master copjes.

Computer Software Control

A code package for computer software design and development shall be maintained that includes the following documentation:

- A description of the problem to be solved or the purpose of the code

- A description of the computer language and operating systern to which the code is adapted

- Input requi rements

- Variables used

- Description of numerical methods and mathematical models

- A record of the progranning progress, problems, and changes made

- User instructions

- Record of computer 1 mplementation of the mathematical models

- Explanation of assumptions, parameters, 11 mitations and theory of the mode?

- Code Iisting.

Computer software developed and subsequent modifications shall be tested and verified by comparison with results from hand calculations.

For codes developed or modified under this project, verification procedures or test plans, controlled in accordance with Section 6.1, shall be prepared identifying the test cases to be run, the input data to be used, the acceptance criteria, and the expected results. The record of verification tests shall be made a part of the code package and maintained in project files. Acquired codes, such as CFEST, shall be reviewed by the Model Enhancements Task Leader for 
QA PLAN ED-41, REV 1

Projects: Hazardous Material Monitoring Project/RCRA

Page 10 of 19

Compliance Ground-Water Monftoring Project

adequacy with the project, as well as adequate documentation (1.e., user's guide/instructions, verification/tests and results). This review shall be documented and retalned as a project record.

7. Technical/Management Review

A review team (see organization chart, Attachment A) shall be employed to provide technical and management review of documents.

Prior to release or issue, reports, studies, and analyses shall be reviewed by member(s) of the review tean not directiy responsibie for the work being reviewed. In this review, reviewers shall, as applicable, assess the adequacy of the data and equations used, duplicate calculations to check the accuracy of the calculations being reviewed, and assess the approprlateness of assumptions being made. The comments shall be documented by written response to the author and shall be resolved by the author. All records of technical/ managenent review shall be stored in project files.

\section{PROCUREMENT}

4.1. This section shall apply to all Items and services that are procured via purchase requisition and purchase order or contract documents. If receiving inspection is required (as specified in PNL-MA-65, Section 4.1.1.4.), then the applicable parts of Sections 9.1 (Inspection and Test) and 12.1 (Inspection, Test, and Operating Status) shall apply.

4.1.1 Subcontractors responsible for the analysis of samples shall be required to:

- Implement the use of written procedures.

- Control the handling of sampies by Chain-of-Custody procedure.

- Control the handling of data records.

- Review and verify result prior to submittal to PNL, documented by signature of lab supervisor.

- The primary analytical laboratory shall implement a documented training program that shall assure that personnel have been trained in laboratory procedures and operation of equipment as necessary.

- Implement a documented Quality Assurance System.

- Provide Quality Assurance surveillance and audits for the Quality Assurance System.

Subcontracted analytical laboratories shall implement a system for control of measurement and test equipment (i.e., calibration) and have issued written procedures for routine 
QA PLAN ED-41, REV 1

Projects: Hazardous Material Monitoring Project/RCRA

Page 11 of 19

Compliance Ground-Water Monitoring Project

analyses, a copy of which shall be kept at the lab and shall be available upon request.

The primary laboratory (currentiy UST) shall participate in the interlaboratory comparison program as provided by the Environmental Protection Agency (EPA) and Environmental Measurements Laboratory (EML) where practicable. Performance in these programs shall be reported to the quality Control Task Manager as they are avallable.

Analytical laboratories shall maintain an internal quality control program to include the use of spiked, blank, and duplicate samples and NBS traceable standards, results of which shall be avallable to PNL for inspection and appraisal.

PNL shall conduct a routine quality control program that includes sending blind, spiked, blank and duplicate samples to UST. Also, PNL shail periodically send replicate field samples to UST and at least two other laboratories to see how well the laboratories agree. The Qualfty Control Program shall be documented, including method, results and reviews.

Evaluation of subcontractor-supplied data is addressed in Section 3, Addition 4 (Data Base Records Verification and Security), Bullet $\$ 5$.

4.1.2 The Statement of Work (SOW) for subcontractors responstble for well drilling shall require subcontractors:

- Follow the requirements set forth in the Subcontract Statement of Work including method of drilling, stean cleaning of equipment, storage of construction materials, tool lubricants, driliing additives, driti cutting and water disposal, and documentation of each of the above.

- Inspections by PNL personnel are required in the Statement of Work. All inspections shall be performed by designated and qualified personnel, documented, and maintained as a record.

- Keep a drilling log which shall be avajlable to the PNL geologist. (Instructions on the format and content of the log shall be included in the sow.) The drilling log shall be maintained as a record.

Purchase Requisitions (PRs) shall be reviewed by an individual familiar with technical specifications of items ordered, 
QA PLAN ED-41, REV 1

Projects: Hazardous Material Monitoring Project/RCRA

Page 12 of 19

Compliance Ground-Water Monitoring Project

and shall be documented by signature/date prior to line manager or other reviews.

All procurement documents shall be reviewed by a Quality Assurance Representative prior to issue to vertfy that the applicable $Q A$ requirements have been included. The subcontractor's written procedures for the above-mentioned activities shall be reviewed by the Project Manager and Quality Assurance Representative.

Subcontractors with extensive $Q A$ requirements shall be approved by PNL Quality Control.

5. INSTRUCTIONS, PROCEDURES, AND DRAWINGS

5.1 Procedures that have been identified for these projects inciude, but are not limited to the following:

- Ground-water Sampling (radiological and chemical), covered in PNL-MA-580, including the following procedures:

- Water Level Measurement

- Conductivity Calibration and Measurement

- pH Calibration and Measurement

- Chain-of-Custody

- Temperature Measurement

- Sampling of River Water, Sediment, and Vegetation (as required)

- Sample Analysis (a)

- Sample Disposal, Procedure P-1

- Data Handling and Verfficatiop (b) Procedure P-2

- Statistical Analysis of Data $(0)$ Procedure P-3

- Indoctrination and Training (PAP-201 Rev. 1; see exceptions noted in 2.1.3)

- Software Design, Development apd Application(including verification procedures/test instructions)

- Geophysical well loggipg (QA PIan ED-54)

- Maga Base Management $(c)$

- Change Control (well drilling), Procedure P-4

(a) Listed in Compliance Plan.

(b) Procedure under development.

(c) This will be included in Hanford Ground-Water Data Base Management Guide and User's Manual when published. 
QA PLAN ED-41, REV 1

Projects: Hazardous Material Monitoring Project/RCRA

Page 13 of 19

Compliance Ground-Water Monitoring Project

Procedures for collection of drilling samples, including both sediment and liquid sampling (including Chain-of-Custody for core samples)

shall be developed and maintained as a project record.

A checklist shall be developed and implemented for Title III Inspection of new wells (see Section 9, Performance of Inspections and Tests).

6. DOCUMENT CONTROL

6.1. This section shall be applied to the procedures identified in 5.1 , and any other documents identified in the future as requiring control. Additional information is provided in the following statement.

6.1.1 Controlled documents shall be revfewed by designated, authorized personnel and approved for the use by the Project Manager or designated alternate. Approval shall be Indicated by signature and date on the document.

The Quality Engineer shall review all controlled documents prior to Issue to help assure that the applicable QA Program requi rements have been adequately met.

6.1.2 Revisions to established procedures shall recelve the same controls applied to the original documents.

In addition:

The Project Manager or designated staff shall be assigned (in wrfting) the responsibility of distribution for all controlled documents.

7. IOENTIFICATION AND CONTROL OF ITEMS

7.1 Sample labeling and identification is covered in the Chain-of-Custody procedure, as noted in Section 5.1 .

9. PERFORMANCE OF INSPECTIONS ANO TESTS

9.1 PNL-MA-65 addresses recelving and other inspection, inspection/test instruction (ITI), and records, tagging, and nonconformance and shall apply to purchased Items, test equipment, samples, project data and computer items.

Tit]e III Inspection of new wells shall be performed by independent, qualified personnel in accordance with the checklist referenced in 5.1 of this plan. The completed checklist shall be retained as a project record. 
QA PLAN ED-41, REV 1

Projects: Hazardous Material Monitoring Project/RCRA

Page 14 of 19

Compliance Ground-Water Monitoring Project

10. CONTROL OF MEASURING AND TEST EQUIPMENT

10.1 Control of measuring and test equipment used shall be in accordance with this section of PNL-MA-65.

In addition:

1. It is the responsibility of the Environmental Monitoring Supervisor or Sample Collection Task Leader to ensure that appropriate project files and records are maintained for all equipment used by the RPTs.

2. Callbration records for $\mathrm{pH} /$ Conductfvity meters iabeled "user to calibrate" shall be documented in the project files. Caltbration shall be in accordance with $\mathrm{pH} /$ Conductivity calibration procedures referenced in Section 5.1 of this QA Plan.

3. Counting equipment for radiological analyses shall be calibrated to Level 1 as spectfied in PNL-MA-65, Section 10.1.

11. MANOLING, STORAGE, AND SHIPPING

11.1 Procedures for Chain-of-Custody handing and transporting samples are documented in the Sampling Procedures, as noted in Section 5.1.

Procedures for disposing of samples are noted in Section 5.1 of this QA Plan.

12. STATUS OF INSPECTION, TEST \& OPERATING CONDITION

12.1 PNL-MA-65 addresses status indication authorities ("lock and tag" procedures) and status indication requirements (tags) which shall apply to test and sample acquisition equipment.

13. NONCONFORMANCE \& CORRECTIVE ACTION

13.1 PNL-MA-65 defines nonconfomance and gives a method for implementing corrective action.

14. QA RECORDS

14.1 The Project Manager or designated alternate shall assure that a project records ffle is maintained that contains or references the location of the $Q A$ records (as noted). Project records shall be retained 
QA PLAN ED-41, REV 1

Projects: Hazardous Material Monitoring Project/RCRA

Page 15 of 19

Compllance Ground-Water Monitoring Project

according to the PNL Records Management Manual (PNL-MA-68). These records shall include, but are not 1 imited to, the following documents:

Records (Record Copy) which are kept by other organizations within Battelle include the following:

Technical reports (numbered) (Technical Information)

Monthly, Quarterly reports (Non-Project) (Department manager) Cost Runs (Finance)

Subcontracts (Legal and Contracts)

Procurement Documents (Legal and Contracts)

Resumes (Personnel)

Project Tralning records (QA, Management Systems)

QA Plan (QA)

QA Audits (QA)

Nonconformance and Corrective Action Reports (QA)

Project records shall include, but are not limited to, the following documents:

Project Proposal, Planning documents

Project Authorization and Directives

Project Monthly, Quarterly and Annual reports

Unpublished Manuscripts

Correspondence influencing direction of the profect

Data Coliection Procedures (PNL-MA-580)

Project Procedures identified in Section 5.1

Laboratory Analysis Methods

Laboratory analysis requests

Procedural changes/comuntcations

Computer Code Documentation fdentified in Section 3

Basic Data

Hard copy from alternate labs

Ran data on tape

Data Base (magnetic media)

Calfbration records

Logbooks

Data Reductfon

Including data sumary, statistical and quality control

Records traceable to Data Base 
QA PLAN ED-41, REV 1

Projects: Hazardous Material Monitoring Project/RCRA

Page 16 of 19

Compliance Ground-Water Monitoring Profect

Laboratory Record Books (numbered)

other notebooks, logbooks

Drawings

Well inspection documentation

Reviews

Records Plan/Index (ref., MG 4.3)

Records Retention:

- Retention periods for project records (record copy only) are specified by DOE Order 1342.2.

- Nonrecord copy retention is determined by the file custodian and project manager.

- Retention times and disposition are documented in the Records Inventory and Disposition Schedule for the RCRA Ground-Water Monitoring and Hazardous Materials Monitoring Project.

- Laboratory Record Books shall be returned to the Technical Lfbrary upon completion of the project for storage indefinitely.

Records Maintenance/Storage:

Records shall be maintalned in project files and subfiles. Records maintenance shall be the responsibility of those custodians listed in the Master File Index and Task/Subtask File Indexes. While in the project file state, records shall be protected from damage or loss in order to avoid potential delays or additional costs of replacement.

Records Transmittal/Disposition:

Reproducible copies of ail profect records with retention times of 15 years or longer shall be transmitted to the Battelle or Federal Records Center annually, after two years of records have been generated. A record of this transinfttal listing all records transferred and uniquely tdentifying them shall be documented and retained by the Profect Manager.

Prior to this transmittal, the QA representative and Profect Manager or designee shall check a sample of the turnover package to verify that sponsor requirements have been met and that the records are legible and complete. 
QA PLAN ED-41, REV 1

Projects: Hazardous Material Monitoring Project/RCRA

Page 17 of 19

\subsubsection{Laboratory Record Books}

Laboratory Record Books shall be controlled in accordance with Section 14.1 .3 of PNL-MA-65.

Laboratory Record Books shall be used for documenting the following activities :

- Sample Collection Notes, Inciuding field measurements, conditions, and operational checks.

15. AUDITS

15.1 Annual audfts shall be performed by the PNL QA Systems and Audtts Section to determine conformance with QA requirements. 
QA PLAN ED-41, REV 1

Projects: Hazardous Material Monftoring Project/RCRA

\section{DISTRIBUTION}

R. L. Aaberg

M. T. Alamia (Training Records)

D. J. Bates

J. F. Bertsch (UNC)

P. E. Bramson

J. V. Carlile

D. R. Dahi

D. S. Daly

C. E. Elderkin

D. R. Elle (DOE)

M. D. Freshley

R. M. Fruland

T. R. Garland

R. 0. Gilbert

H. A. Haerer

M. K. Haniliton (HEHF)

H. W. Hunt (Records)

D. G. Kachele (UNC)

P. J. Krupin (DOE)

T. L. Lifkala

R. L. Martin (WHC)

T. J. McLaughif in

P. J. Mitchell

J. F. Mucha

D. A. Myers

K. R. Oster

M. R. Quarders

QAD c/O G.R. Schmidt

G. Rao (UST)

J. R. Raymond

J. T. Rieger

D. E. Ryder

R. Schaila

R. G. Schreckhise

A. J. Scott

R. W. Stromatt (WHC)

L. W. Vance (UNC)

C. Veverka

M. B. Walter

M. G. Zfmerman (WHC) 
- QA Pian ED-41, Rev. 1
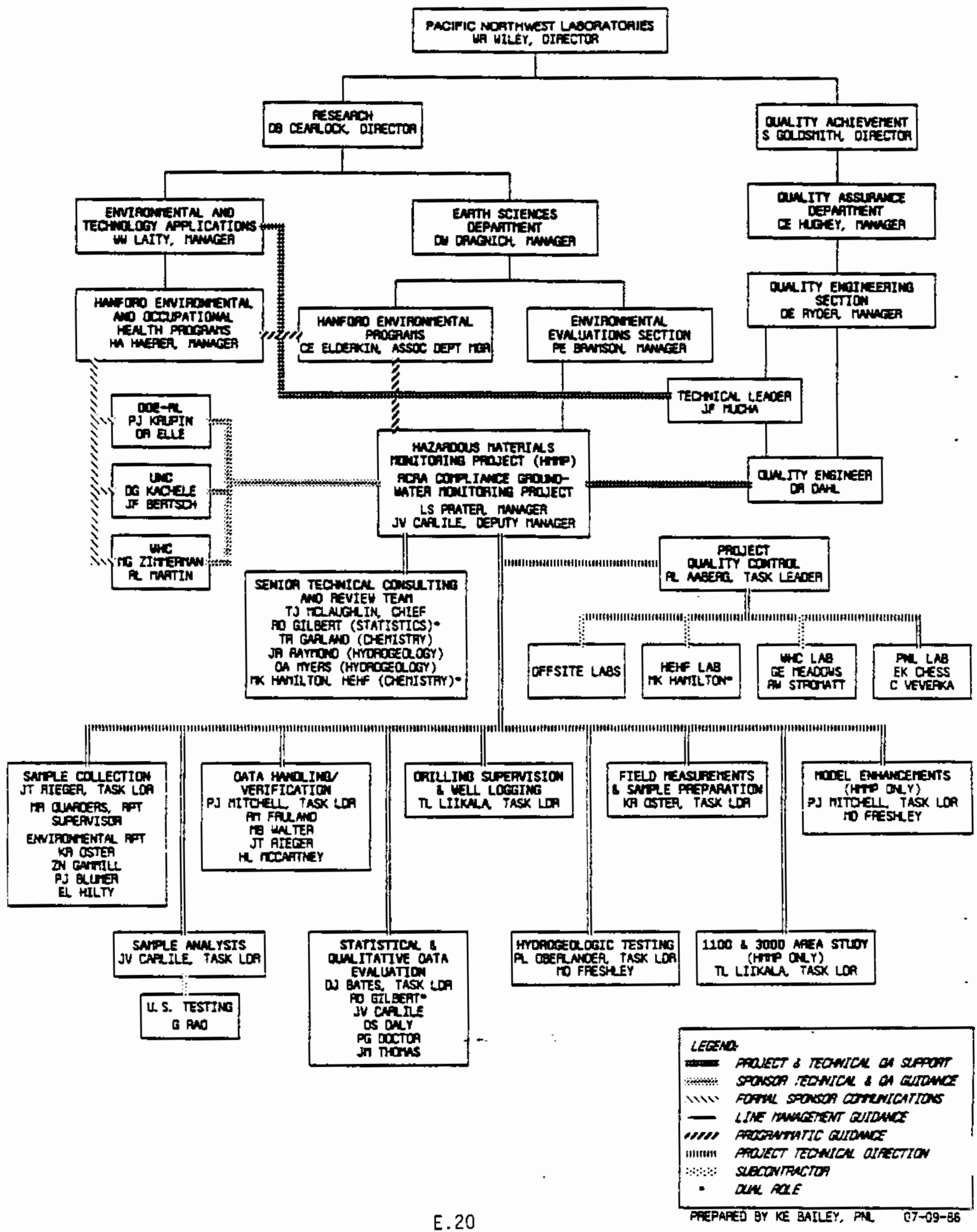
APPENDIX $F$

ANALYTICAL METHODS AND QUALITY CONTROL PROCEDURES 
APPENDIX F

ANALYTICAL METHOOS AND QUALITY CONTROL PROCEDURES

This appendix presents a brief description of each chemical and radiochemical analysis that is performed on samples in accordance with the compliance effort. Following this description, Table 0.1 summarizes the quality control procedures that are part of each analytical procedure.

\section{DESCRIPTION DF ANALYSES}

Temperature, $\mathrm{PH}$, and Conductivity are determined in the field according to field instrument instructions.

Coliform Count is determined by multiple tube fermentation.

Most Metals are measured by either the Inductiveiy Coupled Plasma (ICP) method or the Graphite Furnace Atomic Absorption (GFAA) method. In either case, the sample is first acid-digested. In the ICP method, the digest is then nebuitized, with the resultant aerosol being transported to the plasma torch where excitation occurs. The atomic emission is then measured by an optical spectroscopic technique. In the GFAA method, the digest is dried, ashed, and atomized in a graphite tube furnace. The constituent concentration is proportional to the absorption of hollow-cathode radiation during atomization.

Mercury is measured by the Cold-Vapor Atomic Absorption technique. The mercury is reduced to the elemental state and aerated from solution in a closed system. The mercury vapor passes through a cell positioned in the light path of an atomic absorption spectrophotometer. Absorbance is measured as a function of mercury concentration.

Inorganic Anions are determined by Ion Chromatography (IC). After being injected into the ion chromatograph, the sample is pumped through three different ion exchange columns to convert the anions in the sample to their 
corresponding acids. The separated anions in their acid form are measured using an electrical-conductivity cell.

Volatile and Semi-volatile Organic Chemicals are determined by Gas Chromatography/Mass Spectrometry (GC/MS). Volatile organic chemicals are introduced to the mass spectrometer by the purge-and-trap method, in which the volatile components are converted from an aqueous phase to a vapor phase, trapped on a sorbent column, and then desorbed onto a gas chromatographic column. This column is heated to elute the components, which are then detected by the mass spectrometer. Semi-volatile organic chemicals are extracted using the continuous liquid-liquid extraction method. After being placed in the continuous extraction apparatus, the sample is extracted for 16 hours with the appropriate solvent. The extract is then collected, dried, and concentrated. The extract is eluted from a gas chromatographic fused-silica capillary column, and the eluted components are then detected by the mass spectrometer.

Certain Organic Constituents are analyzed by direct aqueous injection, which requires no preparatory steps before the samples are injected into the gas chromatograph and detected by the mass spectrometer. Substances identified in samples by GC/MS techniques are verified by comparing the suspect mass spectra to the mass spectrum of a standard of the suspected substance. A computerized mass-spectrometry library search system is used that is capable of providing a forward comparison using the standard spectra contained in the Environmental Protection Agency/National Institute of Health mass spectral data base.

Pesticides and Herbicides are measured by gas chromatography with an appropriate detector. Extractions are performed as necessary. Positive concentrations are verified by reanalysis of the extract using a confirmation gas chromatography column or by GC/MS.

Total Organic Halogens (TOX) are measured after the sample is passed through a column containing activated carbon. The column is washed to remove trapped inorganic halides, and the carbon is then analyzed to convert the adsorbed organohalides to a titratable species that can be measured by a microcoulometric detector. 
Total Organic Carbon (TOC) is determined by the combustion-infrared method. The sample is sparged with hydrochloric acid to remove inorganic carbon. The homogenized sample is vaporized with an oxidative catalyst, thereby converting the organic carbon to $\mathrm{CO}_{2}$. The $\mathrm{CO}_{2}$ is measured by means of a nondispersive infrared analyzer.

Antmonium Ion is measured with a specific ion electrode.

Total Alpha-Emjtting Radionuclide measurements are made after the samples are evaporated and the salts and solids are dissolved in nitric acid and extracted from the acid by the diethyl ether method. Each sample is then evaporated, dried on a counting dish, and measured by the $\mathrm{ZnS}$ scintillation counter. The chemical yield is about $83 \%$.

Total Beta-Emitting Radionuclides are measured after each sample has been evaporated onto a l-in. counting dish. The residue is then counted with a gas-flow proportional counter.

Gamma-Emitting Radionuclide data are obtained by analyzing 500 me samples in $0.47-\ell$ polyethylene bottles. An NaI or a Lithium Orifted Germanium $[\mathrm{Ge}(\mathrm{Li})]$ detector are used to count the samples. The standards are traceable to the National Bureau of Standards. The garma-emitting radionuclides of primary interest are ${ }^{137} \mathrm{Cs}$ and ${ }^{60} \mathrm{Co}$. Other garma-emitting radionuciides may be measured as necessary.

Radium is collected from the water sampies by coprecipitation. The precipitate is then dried, weighed, and alpha-counted.

Uranium (natura) is determined with fluorometric techniques following purification by hexone extraction.

Strontium-90 is precipitated with fuming nitric acid, scavenged with barium chromate, precipitated as a carbonate, and counted on a planchet using a gas-flow proportional counter. The yttrium-90 decay product is separated and counted after 15 days. 


\section{TABLE 0.1. Summary of Methods and QC Procedures}

Constituent or Group

Ethylene GTycol

Phosphorus Pestictdes

Herblcides

Organochlorine

Pesticides
Analys is Method

Direct Aqueous Injection GC with Flame Ionization Detector

GC with Flame Photometric Detector (FPO) with Phosphorus Fil ter

GC/Electron Capture Detector (ECD)

GC/ECD

Acid/Base/Neutral (ABN) Semi-Yolatfle Organic Analys is

Volatile Organic Analysis

Anions

IC

GC/MS wth Capillary Colum (Method 8270)

GC/MS Purge and Trap
QC Procedures

- Calibratín curve dajiy

-Mid-range standard every 10th sample ( $\pm 10 \%$ of curve)

-Fortified sample after every 10th sample (estimate matrix effects)

- Standard and fortified sampie at end of run

-Standard (prepared once per week) for 5-point calfbration curve -Mid-range standard every 10th sample to verify $( \pm 10 \%)$

-Matrix spike after every 10th sample

-3-point calibration curve daily Hid-range standard after every 10th sample $( \pm 10 \%)$

- Verification standard at end of batch -Matrix spikes after every 10 samples

(no surrogate)

-Dibutylehlorendate (D8C) surrogate -Reagent blank with every extraction batch

- Matrix sptke after every loth sample - Calibration curve for each compound -Mid-range standard a fter every loth sample ( $\pm 10 \%$ )

- Calibration checked with mid-range standards prior to beginning a run (Hethod 8240)

-MS tuning verified every 12-hour shift -Initial 5-point calibration for each anajy te

-Calibration - verification checked

every 12 -hour shift $( \pm 20 \%)$

-Six surrogate compounds added, recoveries checked

-Matrix spikes

-MS tuning verified every 12-hour shift -5-point calibration for each anaiyte -Calibration verified each 12 -hour shift $( \pm 20$ \%)

- System blanks run before standards -Reagent blank with each batch

-Minimum three surrogate compounds, recovery monitored

-Matrix spike recoveries monitored

-7-point calibration curve

(3-point for perchlorate)

-Mid-range standard to verify internal

calibration ( $\pm 10 \%)$

-Mid-range standard, blank (deionized

water) and matrix spike after every

10th sample. Sample with values over highest calibration standard are diluted and reanalyzed 


\section{TABLE 0.1. Summary of Methods and QC Procedures (cont)}

Constituent or Group

Metals

(As, Se, Pb, Tl)

Citrus Red $\# 2$

Amontum Ion

Suifide

Thiourea

Cyanide

TOC
Analys is Method

GFAA

Spectrophotometer

Specific Ion Electrode (Standard Method 4i7E)

Titration

(SW-846 Method 9030)

High Performance Liquid Chromatography (HPLC)

UV/VIS Spectrophotometer, Colarimetric Method (after distillation)

TOC Anajyzer with Infrared Analyzer (Standard Method 505)
QC Procedures

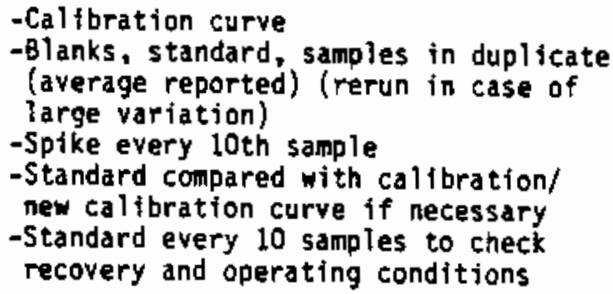

-5-point calibration curve

- Matrix spikes every I0th sample

-Samples exceeding callbration

standards are dfluted and reanalyzed

-Standard and blank are verifled at end of run and/or after 15 samples

-Electrode slope determined -Calibration standards, blank plus 7 -point curve

- Matrix spike after very loth sample - Blank and standard for verification after 10th sample (or beginning and end of smalier run)

-Samples above highest standard are diluted

-Calioration by blank and three standards

- Matrix spike after every loth sampie

-Every 10th sample or end of run, analyze blank and verification standard

-5-point calibration curve, verified every $8 \mathrm{hr}$ and/or at conclusion of run (must be within 10\%)

-After routine analysis, every 10th matrix spike

-Dilution, in case concentration is over highest calibration

-Absorbance wavelength determined by scan of prepared blanks and standards, repeated for each batch of coloring reagent

- Fresh standards run daily, 4-point calibration

-Blank and matrix spike every

10 samples

-5-point calibration curve plus blank, each batch

-Matrix spike after every loth sample

-Calibration is verffied with blank and

standard, which must be within $=10 \%$

of initial calibration, after each

run

-If a sample falls above the highest

calibration standard, it is diluted and reanalyzed 


\section{TABLE 0.1. Summary of Methods and QC Procedures (cont)}

Constituent or Group

Mercury

TOX

Metais

Coliform Bacteria

Radioactivity:

Radium

A1pha Direct (AD)

Beta Direct (BD)
Analysis Method

\section{Cold Vapor Atomic} Absorption (Method 7470)

Carbon Absorption, Mierocoul ometric Titration (Method 9020)

ICP Spectrograph (Hethod 6010)

Presumptive Test, Confimation Test

Precipitate, Weigh, Count

Evaporate, Count

Evaporate, Count
QC Procedures

-Calibration, blank and four standards prepared for eack batch

- Duplicate and matrix spike every 10 samples

- One verification standard for every

10 samples

- Quality control sample from outside

source at least every other batch

-Callbration involves:

-Two titration cell standards (to $\pm 5 \%$ )

-Nitrate wash blanks (method blanks)

- Instrument calibration standards after eight pyrolys is determinations and after cleaning or reconditioning - Every sample run in duplicate

-Matrix spike on 105 of sample, Dercent recovery detemination

-Outside standard analyzed weekly

-Calibration involves: -Warm-up, configuration, calibration procedure, flush system with blank between each sample

-Dilute samples if above hich standard -One reagent blank with each batch

-Ouplicate samples for $10 \%$

-Matrix spike on 10\% of samples

- Check standardization by anaiyzing quality control standards, $10 \%$ of

samples (to within $( \pm 10 \%$ )

-Calibration blanks, I0\%

-Run standard after batch (check drift)

- Reagents are routinely analyzed for contamination

- Media are autoclaved and analyzed

with every batch

-Every IOth sample is analyzed in duplicate

-Blank and spike samples

-Blank and spike samples

-Blank and spike samples 